$W R I-73-002$

SOLMNEQ: SOLUTION-MINERAL EQUILIBRIUM COMPUTATIONS

Yousif K. Kharaka, et al

California University

Prepared for:

Geological Survey

February 1973

DISTRIBUTED BY:

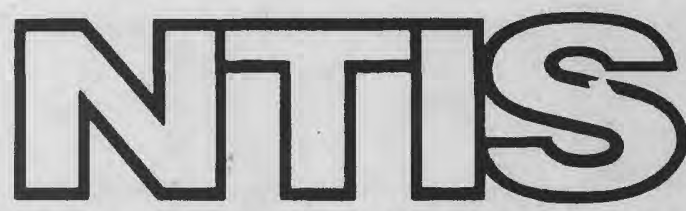

National Technical Information Service U. S. DEPARTMENT OF COMMERCE 5285 Port Royal Road, Springfield Va. 22151 


\section{KEEP UP TO DATE}

Between the time you ordered this reportwhich is only one of the hundreds of thousands in the NTIS information collection available to you-and the time you are reading this message, several new reports relevant to your interests probably have entered the collection.

Subscribe to the Weekly Government Abstracts series that will bring you summaries of new reports as soon as they are received by NTIS from the originators of the research. The WGA's are an NTIS weekly newsletter service covering the most recent research findings in 25 areas of industrial, technological, and sociological interestinvaluable information for executives and professionals who must keep up to date.

The executive and professional information service provided by NTIS in the Weekly Government Abstracts newsletters will give you thorough and comprehensive coverage of government-conducted or sponsored re- search activities. And you'll get this important information within two weeks of the time it's released by originating agencies.

WGA newsletters are computer produced and electronically photocomposed to slash the time gap between the release of a report and its availability. You can learn about technical innovations immediately-and use them in the most meaningful and productive ways possible for your organization. Please request NTIS-PR-205/PCW for more information.

The weekly newsletter series will keep you current. But learn what you have missed in the past by ordering a computer NTISearch of all the research reports in your area of interest, dating as far back as 1964, if you wish. Please request NTIS-PR-186/PCN for more information.

WRITE: Managing Editor 5285 Port Royal Road Springfield, VA 22161

\section{Keep Up To Date With SRIM}

SRIM (Selected Research in Microfiche) provides you with regular, automatic distribution of the complete texts of NTIS research reports only in the subject areas you select. SRIM covers almost all Government research reports by subject area and/or the originating Federal or local government agency. You may subscribe by any category or subcategory of our WGA (Weekly Government Abstracts) or Government Reports Announcements and Index categories, or to the reports issued by a particular agency such as the Department of Defense, Federal Energy Administration, or Environmental Protection Agency. Other options that will give you greater selectivity are available on request.

The cost of SRIM service is only $45 \phi$ domestic (60ф foreign) for each complete microfiched report. Your SRIM service begins as soon as your order is received and processed and you will receive biweekly shipments thereafter. If you wish, your service will be backdated to furnish you microfiche of reports issued earlier.

Because of contractual arrangements with several Special Technology Groups, not all NTIS reports are distributed in the SRIM program. You will receive a notice in your microfiche shipments identifying the exceptionally priced reports not available through SRIM.

A deposit account with NTIS is required before this service can be initiated. If you have specific questions concerning this service, please call (703) $451-1558$, or write NTIS, attention SRIM Product Manager.

\section{This information product distributed by}

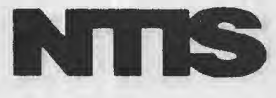

U.S. DEPARTMENT OF COMMERCE

National Technical Information Service

5285 Port Royal Road

Springfield, Virginia 22161 


\author{
UNITED STATES \\ DEPARTMENT OF THE INTERIOR \\ GEOLOGICAL SURVEY \\ COMPUTER CONTRIBUTION
}

SOLMNEQ: Solution-Mineral Equilibrium Computations

by

Yousif K. Kharaka and Ivan Barnes

U.S. Geological Survey

Menlo Park, California

February 1973

Program Number:

G204

Sponsor:

Joseph T. Callahan and Gerald Neyer

Equipment :

IBM $360 / 65$

Operating System:

Language :

IBM System 360

PL/I ( $F-L E V E L)$ 


$$
\begin{array}{llllll}
\mathbf{N} & \mathbf{O} & \mathrm{T} & \mathbf{I} & \mathrm{C} & \mathbf{E}
\end{array}
$$

THIS DOCUMENT HAS BEEN REPRODUCED FROM THE BEST COPY FURNISHED US BY THE SPONSORING AGENCY. ALTHOUGH IT IS RECOGNIZED THAT CERTAIN PORTIONS ARE ILLEGIBLE, IT IS BEING RELEASED IN THE INTEREST OF MAKING AVAILABLE AS MUCH INFORMATION AS POSSIBLE. 


\section{SOLMNEQ: Solution-Mineral Equilibrium Computations}

Aurhor(s) Yousif K. Kharaka, University of California, Berkeley Ivan Barnes, U.S. Geological Sunvey

- Performing Organization liame and Address

Geology $\varepsilon$ Geophysics Dept.,University of California,Berkeley Berkeley. California 94620

U.S. Geolugical Survey, Menlo Park, California.94025

12. Sponsoring Organization Name and Address

U.S. Geological Survey, Water Resources Division

Washington, D. C. 20244

6.

8. Performing Organization Rept. No.

10. Project'Task/liork Linit lo.

11. Contrac: Gránt $\therefore$.

Grant No. 14-08-0001G-45

13. Type of Report \& Period Covered

Final

15. Supplementary Notes

16. Abstracts

SOTMNEQ is a computer program written in PL/I for the IBM 360 computers. SOLMNEQ computes the equilibrium distribution of 162 inorganic aqueous species generally present in natural waters over the temperature range of $0^{\circ}$ to $350^{\circ} \mathrm{C}$ from the reported chemical analyses, temperature, $\mathrm{pH}$, and $\mathrm{Eh}$ (optional). Interpolated dissociation constants of the aqueous complexes and the computed activity coefficients are also used in these computations. States of reactions of the aqueous solutions with respect to 158 solid phases (minerals) are computed from the distribution of aqueous species and an internally consistent set of thermodynamic data. Ionic proportions and subsurface temperature estimates are computed.

17. Kị hords and Document Analysis. 17a. Wescriptors

*Chemicãl reactions, *Water chemistry, *Computer programs, *Geothermometry, Chemical equilibrium, Thermodynamics, Chemical properties

17b. Ideneifiers/Open-Ended Terms

*SOLMNEQ, Solution-mineral equilibrium, Water-rock interaction

\section{PRCES SUBJEC TO OHANE:}

17c. (Mdil Fichlaroup $0802,0702,0808$

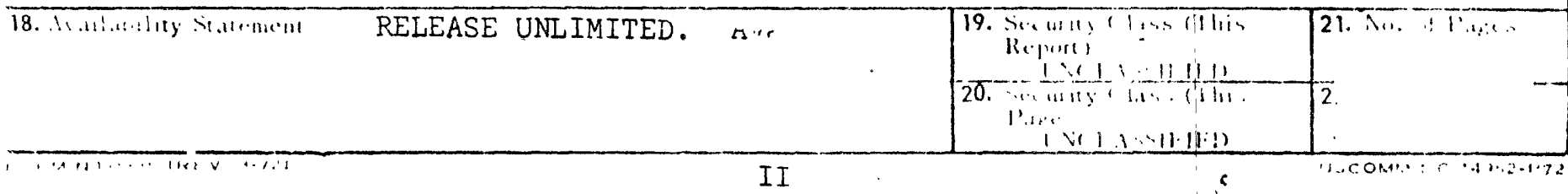


Computer Contributions are arallable (\$0.95 for mlcroliche copy, \$3.00 for paper copy) from the National Technical Information Service, Springfield, Virginia 22151. When ordering, refer to the title and the PB number.

PB-203 580 Welghted Triangulation Adjustment, by Walter I. Anderson, 1969

PB-195 999 Perspective Center Determination, by John D. McLaurin, 1969

PB-203 568 Nonconstant Varlance Regres81on Analysis Program, by Marshall Strong Bellmann, 1970

PB-206 417 Hot Pipe, by Patrick C. Doherty, 1970

PB-190 628 Proceedings of the Syruosium on Map and Chart Digit1zing, 1970

PB-194570 Atlantic Region Semianalytical Aerotrlangulation Program, by Leonard R. Mannello, Morris I. MeKenzle and Robert Kont gomery, Jr., 1970

PB-203 581 Mineral Distribution Program - Mod II (for solving Petrologic Mixing Problems), by Patrick C. Doberty and Thomas L. Wright, 1971

PB-203 140 Generat1on and Testing of Random Numbers, by ILcholas C. Natalas and Marshall Strong Hellmann, 1971

PB-209 838 X-ray Diffractometer Data Reduction Procram, by Iarshall Strong Hellmann, 1971

PB-196979 Iterative Three-Dimensional Solution of Oravity Anomaly Data, by Lindrith Cordell, 1970

PB-203 787 The STATPAC System, by Fred B. Sower, Ralph H. Ilcher and Gary I. Selner, 1971

PB-209 839 Trensient Flow, by Marshall Strong Hellmann, 1971

PB-206 736 Graphlc Normative Analysis Program, by Roger W. Borren, 1971

PB-203 726 Calculation of Pseudo-gravity Anomaly from Total Magnetic Intensity Data, by Iindrith Cordell, 1971 
PB-203 725 Solution of Combined Gravity and Magnet1c Data for Physical Properties, by Lindrith Cordell and Patrick T. Taylor, 1971

PB-207 710 Calculation of Amplbole Structural Formulae, by Freser $\mathbf{B}$. Goff and Gerald K. Czamanske, 1972

PB-207 523 Program PR申pL3, A Generalized Proflle Plotting Program, by A. Graig Mcliendrie, 1972

PB-208 679 A FORIRAN IV Computer Program for Calculating Borehole Gravity Terrain Corrections, by I. A. Beyer and C. I. Corbato, 1972

PB-214 359 Rosenbrock technique for determining greatest or least value of a function, by P. H. Carrigan, Jr., 1973

PB-214 416 Reservo1r bank etorage, by T. H. Thompson, 1973 
Abstract-1- 1

Introduction- 2

Method of computation- 4

Activities-_- 4

Activity coefficients-_- 14

Equilibrium constants-_- 17

Oxidation-reduction reactions-_. 22

Distribution of species in solution-_. 23

Gibbs free energy functions-_- 26

Input-- 29

Output (results) 32

References cited- 39

Appendix 1. Listing of SOLMNEQ- 45

Appendix 2A. Table of $\log (\mathrm{KT})$ for the aqueous complexes

and minerals-- 68

Appendix 2B. List of aqueous species together with their

charge, distance of nearest approach $\left(a^{\circ}\right)$, and gram

formula weight- 74

Appendix 2C. Activity coefficient of $\mathrm{CO}_{2(\mathrm{aq})}$ as a function

of temperature and an equivalent $\mathrm{NaCl}$ solution--.-- 75

Appendix 2D. Values of deviation function $B^{\cdot}$ as a function

of temperatures of Appendix 2C- 75

$25-$

Appendix 3. Printout of results obtained for a test sample-- 
$5-$

6

7

8

10

11

12

13

14

$15-$

16

17

18

19

20

ข1

ンะ

2:

24

25

\section{TABLES}

Page

Table 1. List of the aqueous complexes and minerals used in SOLMNEQ. The source of data for the $\log (\mathrm{KT})$ values of the given reactions is indicated-...-.-.-

2. List of identifiers used in SOLMNEQ and their significance-- 
SOLMNEQ: Solution-Mineral Equilibrium Computations ${ }^{1}$

Yousif K. Kharaka ${ }^{2}$

University of California, Berkeley

and

Ivan Barnes

U.S. Geological Survey

\section{ABSTRACT}

SOLMNEQ is a computer program written in PL/I for the IBM 360 computers. SOLMNEQ computes the equilibrium distribution of 162 inorganic aqueous species generally present in natural waters over the temperature range of $0^{\circ}$ to $350^{\circ} \mathrm{C}$ from the reported chemical analyses, temperature, $\mathrm{pH}$, and Eh (optional). Interpolated dissociation constants of the aqueous complexes and the computed activity coefficients are also used in these computations. States of reactions of the aqueous solutions with respect to 158 solid phases (minerals) are computed from the distribution of aqueous species and an internally consistent set of thermodynamic data. Ionic proportions and subsurface temperature estimates are computed.

${ }^{1}$ This research was sponsored by the U.S. Geological Survey, Department of the Interior, under U.S.G.S. Grant No. 14-08-0001G-45. F.A.F. Berry, principal investigator.

2Headquarters at U.S. Geological Survey, Menlo Park, California. 


\section{INTRODUCTION}

Analyses of states of chemical reaction have been made using equilibrium models (Helgeson and others, 1970; Truesdell, 1973) and models that include departures from equilibrium (Pačes, 1968, 1971; Barnes and Clarke, 1969; A. H. Truesdell and B. F. Jones, unpub. data: The present program, incorporating elements from the earlier cited work, has been expanded to include all inorganic species of major and minor elements generally present in natural waters for which thermodynamic data are available.

SOLMNEQ computes the equilibrium distribution of 162 chemical species in aqueous solution over the temperature range of $0^{\circ}$ to $350^{\circ} \mathrm{C}$ from the properties of the solution and an internally consistent set of thermodynamic data. States of reaction of the aqueous solutions with respect to 158 solid phases (minerals) are also computed. Uncertainties involved in computations carried out in SOLMNEQ and similar computer programs should be recognized at the outset. Major uncertainties may be imposed by the amount and quality of the thermodynamic and other data available in published literature for the computations of equilibrium constants $(K)$. The uncertainties in the thermodynamic functions depend on the rate and reversibility of the reactions involved. The more rapidly, completely, and reversibly a phase reacts, the less error is to be expected in its thermodynamic functions. 
Usefulness of the data analysis is limited also by the completeness and reliability of the reported chemical analysis of the water. Many chemical analyses are limited to the major cations and anions. Uncertainties are imposed by the method of sample collection and treatment and method of analysis (Chave, 1960; Rainwater and Thatcher, 1960; White, 1965; Barnes and others, 1969). An important limitation of many chemical analyses is the extrapolation of the determined $\mathrm{pH}$ to the in situ pH of the sample, especially in the case of subsurface water samples. The $\mathrm{pH}$ of the sample may change from variations in partial pressures of the gases present $\left(\mathrm{CO}_{2}, \mathrm{H}_{2} \mathrm{~S}\right.$, and others), from precipitation of solid phases (for example, $\mathrm{CaCO}_{3}, \mathrm{SrCO}_{3}$ ), and from reactions of aqueous species produced by changes in the temperature and pressure of the sample. An additional limitation of the data analysis applies to studies of aluminosilicate minerals and minerals containing trace elements. Results of analyses for aluminum in solution in the literature are suspect because of the lack of a sufficiently sensitive analytical method. Trace element analyses are particularly subject to errors from insensitive procedures, sample contamination, and losses during storage and manipulation.

Assumptions used in the calculation of the activity coefficients of the aqueous species and in limiting minerals to end member compositions introduce errors, but generally these errors are minor compared to those mentioned above. 


\section{METHOD OF COMPUTATION}

SOLMNEQ treats mostly mass action reactions; however, there is an option to calculate the molalities $(\mathrm{m})$ of $\mathrm{Fe}^{+3}, \mathrm{Cu}^{++}, \mathrm{Hg}^{++}$, and $\mathrm{Mn}^{++}$ using electron transfer reactions involving the measured Eh of the aqueous sample. The formal reactions used for the minerals (table 1 )

aro for the complete reactions; no incongruent reactions are used. For albite, for example, the reaction is:

$$
\mathrm{NaAlSi}{ }_{3} \mathrm{O}_{8}+4 \mathrm{H}^{+}+4 \mathrm{H}_{2} \mathrm{O}=\mathrm{Na}^{+}+\mathrm{AI}^{+3}+3 \mathrm{H}_{4} \mathrm{SiO}_{4}
$$

\section{Activities}

The activities (a) of solid phases are taken as unity at all temperatures. The activity of $\mathrm{H}_{2} \mathrm{O}$ is computed from the equation (Sarrels and Christ, 1965, p. 65)

$$
a_{\mathrm{H}_{2} \mathrm{O}}=1-\underline{0.017} \sum_{i} \mathrm{~m}_{i}
$$

the summation covering the molalities $\left(m_{i}\right)$ of all the species in solution.

The activities of the aqueous species are computed from:

$$
a_{i}=m_{i} \gamma_{i}
$$

where $\gamma_{i}$ is the activity coefficient of species $i$. The standard state adopted for the aqueous species is a hypothetical 1 molal solution at I atmosphere and at any temperature. 


\section{A - AQUEOUS COMPLEXES}
1.
$\mathrm{HCO}_{3}^{-} \rightleftharpoons \mathrm{CO}_{3}^{--}+\mathrm{H}^{+}$
2. $\mathrm{KH} 20$
3. $\mathrm{H}_{4} \mathrm{SIO}_{4}$
$\mathrm{H}_{2} \mathrm{O} \rightleftharpoons \mathrm{OH}^{-}+\mathrm{H}^{+}$
$\mathrm{H}_{4} \mathrm{SiO}_{4} \rightleftharpoons \mathrm{H}_{3} \mathrm{SiO}_{4}^{-}+\mathrm{H}^{+}$
4. $\mathrm{Cl}+2$
5. $E E+3$
6. $H G+2$
7. $M N+3$
3. $\mathrm{AS}(\mathrm{OH}) 4-$
$\mathrm{Cu}^{++}+\mathrm{IO}^{++} \rightleftharpoons \mathrm{Cu}^{+}+\mathrm{He}^{+3}$
$\mathrm{Fe}^{+3}+\frac{1}{2} \mathrm{H}_{2} \mathrm{O}+\frac{1}{8} \mathrm{HS}^{-} \rightleftharpoons \mathrm{Fe}^{++}+\frac{1}{8} \mathrm{SO}_{4}^{--}+\frac{9}{8} \mathrm{H}^{+}$
$2 \mathrm{Hg}^{++}+2 \mathrm{Fe}^{++} \rightleftharpoons \mathrm{Hg}_{2}^{++}+2 \mathrm{Fe}^{+3}$
$\mathrm{Mn}^{+3}+\mathrm{Fe}^{++} \rightleftharpoons \mathrm{Mn}^{++}+\mathrm{Fe}^{+3}$
$\mathrm{As}(\mathrm{OH})_{4}^{-} \rightleftharpoons \mathrm{As}(\mathrm{OH})_{3}+\mathrm{OH}^{-}$
9. Blank
io. $H 2 S A Q$
11. $A L F+2$
12. ALF2+1
13. ALF3
14. ALF4-
15. $\mathrm{AL}(\mathrm{OH})+2$
16. AL $(\mathrm{OH}) 2+$
17. $\mathrm{AL}(\mathrm{OH}) 4-$
18. AL(SOL)+
19. $\left.\mathrm{ALSO}_{4}\right) 2-$
20. AGCL
21. AGCL2-
22. AGCL3-2
23. AGCL4-3
24. $A G(504)-$
25. AGSO42-3
26. BA.CO3AQ
27. BAHCOO I+
28. $\mathrm{BA}(\mathrm{OH})+2$
29. $\mathrm{BASO}_{4} \mathrm{AQ}$
30. $\operatorname{CACu} 3 \wedge Q$
31. (Al:CO3)+
$32 . \mathrm{CA}($ S) 1$)+$ ?
33. $\mathrm{CAPO} 4$ -
34. CA:HL
35. CAlBrinit
$\mathrm{Al}\left(\mathrm{SO}_{4}\right)_{2}^{-} \rightleftharpoons \mathrm{Al}^{+3}+2 \mathrm{SO}_{4}^{--}$
$\mathrm{AgCl}_{2}^{-} \rightleftharpoons \mathrm{Ag}^{+}+\mathrm{Cl}^{-}$
$\mathrm{AgCl}_{3}^{--} \rightleftharpoons \mathrm{Ag}^{+}+\mathrm{Cll}^{-}$
$\mathrm{ACCl}_{4}^{-3} \rightleftharpoons \mathrm{Ag}^{+}+4 \mathrm{Cl}^{-}$
$\mathrm{Ar}\left(\mathrm{SO}_{4}\right)^{-} \rightleftharpoons \mathrm{Ag}^{+}+\mathrm{SO}_{4}^{--}$
$\mathrm{A}_{4}\left(\mathrm{SO}_{4}\right)_{2}^{-3} \rightleftharpoons \mathrm{Ag}^{+}+2 \mathrm{SO}_{4}^{--}$
$\mathrm{BaCO}_{3} \rightleftharpoons \mathrm{Ba}^{++}+\mathrm{CO}_{3}^{--}$
$\mathrm{ba}\left(\mathrm{HO}_{3}\right)^{+} \rightleftarrows \mathrm{Ba}^{++}+\mathrm{HCO}_{3}^{-}$

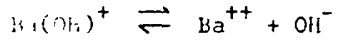
$\mathrm{BaSO}_{4} \rightleftharpoons \mathrm{Ba}^{++}+\mathrm{SO}_{4}^{--}$
$\mathrm{CaCO}_{3} \rightleftharpoons \mathrm{Ca}^{++}+\mathrm{CO}_{3}^{--}$
Cances $\rightleftharpoons \mathrm{Ca}^{++}+\mathrm{HCO}_{3}^{-}$
$\mathrm{CH}(\mathrm{OH})^{+}=\mathrm{Ca}^{++}+\mathrm{CHi}^{-}$
$\mathrm{CarO}_{4}^{-} \rightleftharpoons \mathrm{Ca}^{+1}+\mathrm{PO}_{4}^{-3}$
$\because \therefore \rightleftharpoons \therefore+t+\mathrm{HI}^{+-}$
Cat: : ${ }^{+} \rightleftharpoons \mathrm{Cl}^{++}+\mathrm{H}_{2} \mathrm{IO}_{4}^{-}$

(3)

Fisher and Barnes (1972)

Cobble (1964)

K (1)

K (1)

K (1)

K (1)

D (1)

D (3)

D (3)

D (3)

D. (3)

(1)

(25) Hem and Roberson (1967)

\section{Helgeson (1971c)}

D (3)

D (3)

(1)

(1)

(1)

D (3)
Kharaka and Merino (unpub. data, 1971)

(1)

D (Lafon, 2969)

PATHI, helgeson and others (1970)

Chughtai and others (1962)

Chuglitai and others (196s)

Cluphltat $i$ and others (1968) 


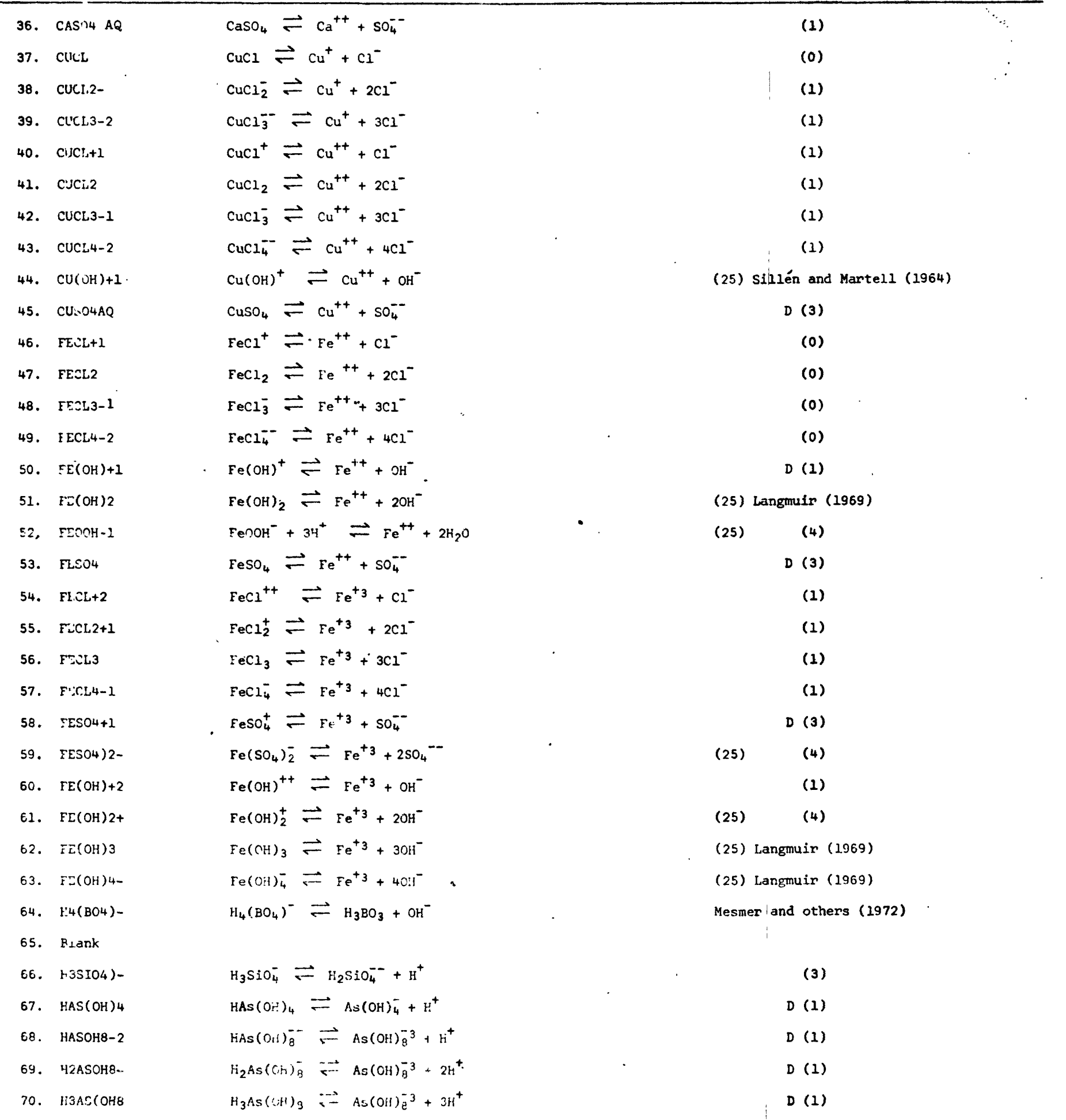


71. $H F$

72. $\mathrm{H} 2 \mathrm{CO}$

73. $\mathrm{HPO} 4-2$

74. $\mathrm{H}_{2} \mathrm{PO}_{4-1}$

75. HS $\cdot 1$

76. $\mathrm{HS} / 4-1$

77. $\mathrm{HNO}_{3}$

78. $\mathrm{HGCL+1}$

79. HiCL2

80. HGCL3-1

81. HGCL4-2

82. $\mathrm{HGSO} 4$

83. HGSH 2S) 2

84. $\mathrm{HG}(\mathrm{HS}) 3-$

85. HGSHS2-2

86. $\mathrm{KCL}$

87. $\mathrm{HGS}_{-2}-2$

88. KISU4

89. $\mathrm{KSO}^{-1}$

90. КMPO4-1

91. $\mathrm{LI}(\mathrm{OH})$

92. LI(SO4)-

93. MGCUJAQ

94. Masi(O) )+

95. Mar. 1

96. $M G(U H)+1$

97. MISUAA2

98. $\mathrm{MG}(\mathrm{PO4})-$

89. $\mathrm{MCHFO} 4$

100. MGH2PO4+

101. MNCL+1

102. MNCL2

103. MIICL3-1

10t. MNC! 4-2

Jas. MntiCO3+1
$\mathrm{HF} \rightleftharpoons \mathrm{H}^{+}+\mathrm{F}^{-}$

$\mathrm{H}_{2} \mathrm{CO}_{3} \rightleftharpoons \mathrm{HCO}_{3}^{-}+\mathrm{H}^{+}$

$\mathrm{HPO}_{4}^{--} \rightleftharpoons \mathrm{PO}_{4}^{-3}+\mathrm{H}^{+}$

$\mathrm{H}_{2} \mathrm{PO}_{4}^{-} \rightleftharpoons \mathrm{HFO}_{4}^{--}+\mathrm{H}^{+}$

$\mathrm{HS}^{-} \rightleftharpoons \mathrm{H}^{+}+\mathrm{S}^{--}$

$\mathrm{HSO}_{4}^{-} \rightleftharpoons \mathrm{H}^{+}+\mathrm{SO}_{4}^{--}$

$\mathrm{HHO}_{3} \rightleftharpoons \mathrm{NO}_{3}^{-}+\mathrm{H}^{+}$

$\mathrm{HgCl}^{+} \rightleftarrows \mathrm{Hg}^{++}+\mathrm{Cl}^{-}$

$\mathrm{HgCl}_{2} \rightleftharpoons \mathrm{Hg}^{++}+2 \mathrm{Cl}^{-}$

$\mathrm{HgCL}_{3}^{-} \rightleftharpoons \mathrm{Hg}^{++}+\mathrm{Cl}^{-}$

$\mathrm{HgCl}_{4}^{--} \rightleftharpoons \mathrm{Hg}^{++}+4 \mathrm{Cl}^{-}$

$\mathrm{HgSO}_{4} \rightleftharpoons \mathrm{Hg}^{++}+\mathrm{SO}_{4}^{--}$

$\mathrm{HgS}\left(\mathrm{H}_{2} \mathrm{~S}_{2}+\mathrm{H}^{+} \rightleftharpoons \mathrm{Hg}^{++}+2 \mathrm{H}_{2} \mathrm{~S}+\mathrm{HS}^{-}\right.$

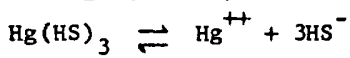

$\mathrm{HgS}(\mathrm{HS})_{2}^{--}+\mathrm{H}^{+} \rightleftharpoons \mathrm{Hg}^{++}+3 \mathrm{HS}^{-}$

$\mathrm{KCl} \rightleftharpoons \mathrm{K}^{+}+\mathrm{Cl}^{-}$

$\mathrm{HgS}_{2}^{--}+2 \mathrm{H}^{+} \rightleftharpoons \mathrm{Hg}^{++}+2 \mathrm{HS}^{-}$

$\mathrm{KHSO}_{4} \rightleftharpoons \mathrm{K}^{+}+\mathrm{HSO}_{4}^{-}$

$\mathrm{KSO}_{4}^{-} \rightleftharpoons \mathrm{K}^{+}+\mathrm{SO}_{4}^{--}$

$\mathrm{KHPO}_{4}^{-} \rightleftharpoons \mathrm{K}^{+}+\mathrm{HPO}_{4}^{--}$

$\mathrm{Li}(\mathrm{OH}) \rightleftharpoons \mathrm{Li}^{+}+\mathrm{OH}^{-}$

$\mathrm{Li}\left(\mathrm{SO}_{4}\right)^{-} \rightleftharpoons \mathrm{Li}^{+}+\mathrm{SO}_{4}^{--}$

$\mathrm{MgCO}_{3} \rightleftharpoons \mathrm{Mg}^{++}+\mathrm{CO}_{3}^{--}$

$\mathrm{Mg}\left(\mathrm{HCO}_{3}\right)^{+} \rightleftharpoons \mathrm{Mg}^{++}+\mathrm{HCO}_{3}^{-}$

$\mathrm{MgF}^{+} \rightleftharpoons \mathrm{Mg}^{++}+\mathrm{F}^{-}$

$\mathrm{Mg}(\mathrm{OH})^{+} \rightleftharpoons \mathrm{Mg}^{++}+\mathrm{OH}^{-}$

$\mathrm{ME}_{8} \mathrm{SO}_{4} \rightleftharpoons \mathrm{N}_{5}^{++}+\mathrm{SO}_{4}^{--}$

$\mathrm{Mg}\left(\mathrm{PO}_{4}\right)^{-} \rightleftharpoons \mathrm{Mg}{ }^{++}+\mathrm{PO}_{4}^{-3}$

$\mathrm{NgHPO}_{4} \longrightarrow \mathrm{Ng}^{++}+\mathrm{HPO}_{4}^{--}$

$\mathrm{ME}\left(\mathrm{H}_{2} \mathrm{FO}_{4}\right)^{+} \rightleftharpoons \mathrm{Mg}^{++}+\mathrm{H}_{2} \mathrm{PO}_{4}^{-}$

$\mathrm{MnCl}^{+} \rightleftharpoons \mathrm{Mn}^{++}+\mathrm{Cl}^{-}$

$\mathrm{MnCl}_{2} \rightleftharpoons \mathrm{Kn}^{++}+2 \mathrm{Cl}^{-}$

$\mathrm{MnCl}_{3}^{-} \rightleftharpoons \mathrm{Nn}^{++}+3 \mathrm{Cl}^{-}$

$\mathrm{MnCl}_{4}^{--} \rightleftharpoons \mathrm{Mn}^{1+}+4 \mathrm{Cl}^{-}$

$\mathrm{IniCO}_{3}^{+}=\mathrm{Mn}^{++}+\mathrm{HOO}_{3}^{-}$
(3)

Ellis and Giggenbach (1971)

D(1)

D (1)

D(1)

D (1)

(25) (4)

D (Barnes and others, 1967)

(25) (Barnes snd others, 1967)

(25) (Bsrnes and others, 1967)

Truesde11 and Jones (unpub. data, 1972)

(25) Barnes and others, 1967)

(0)

Truesdell and Jones (unpub. data, 1972)

(0)

Sillén and Martell (1964)

(25) Sillén and Martell (1964) .

D (Lafon, 1969)

D (Lafon, 1969)

D (3)

Childs (1970); Chughtai and others (1968) Childs (1970); Chughtai and others (1968) Childs (1970); Chughtai and others (1968)

(0)

(25)

(4)

(25)

(0)

(0) 


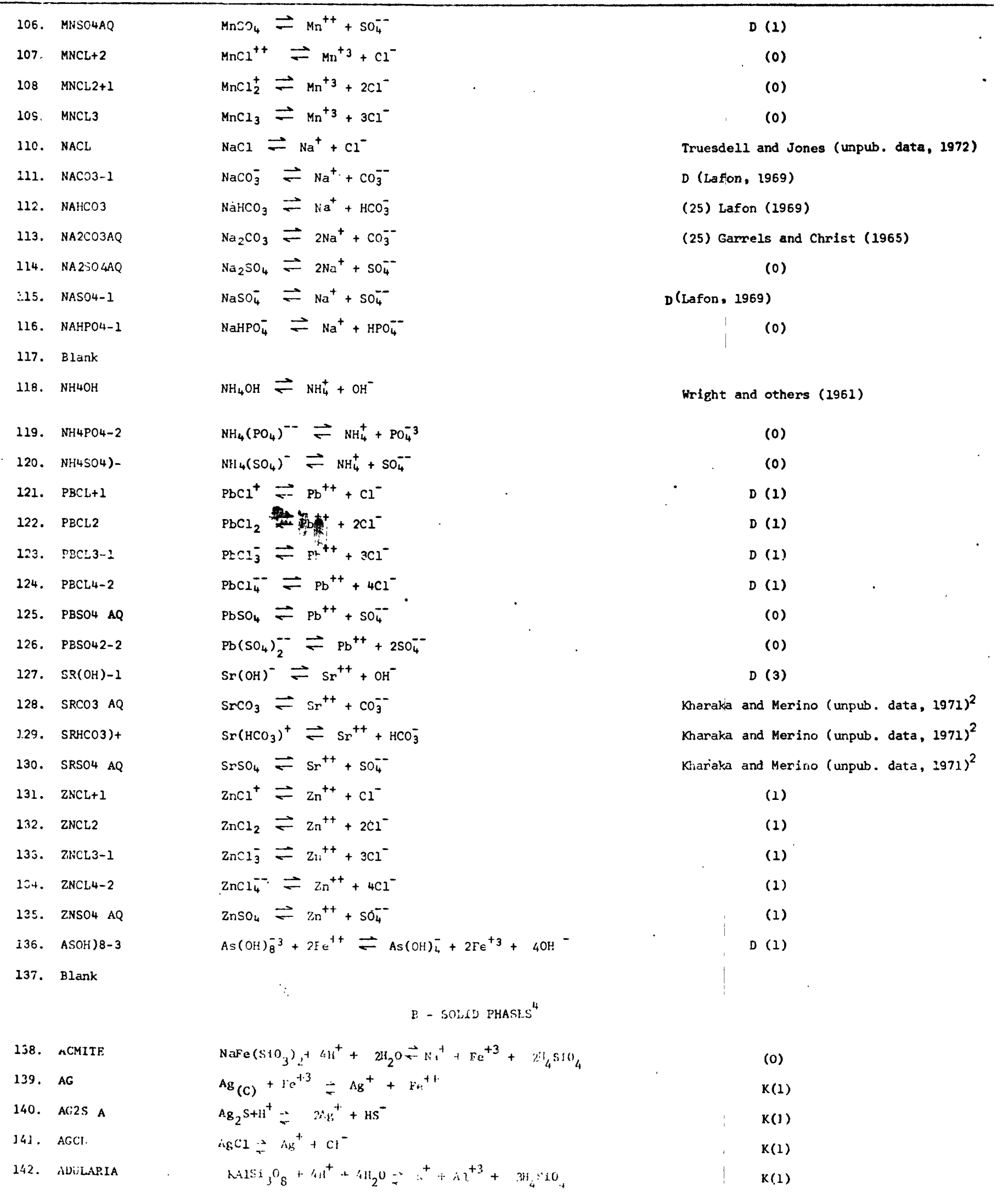




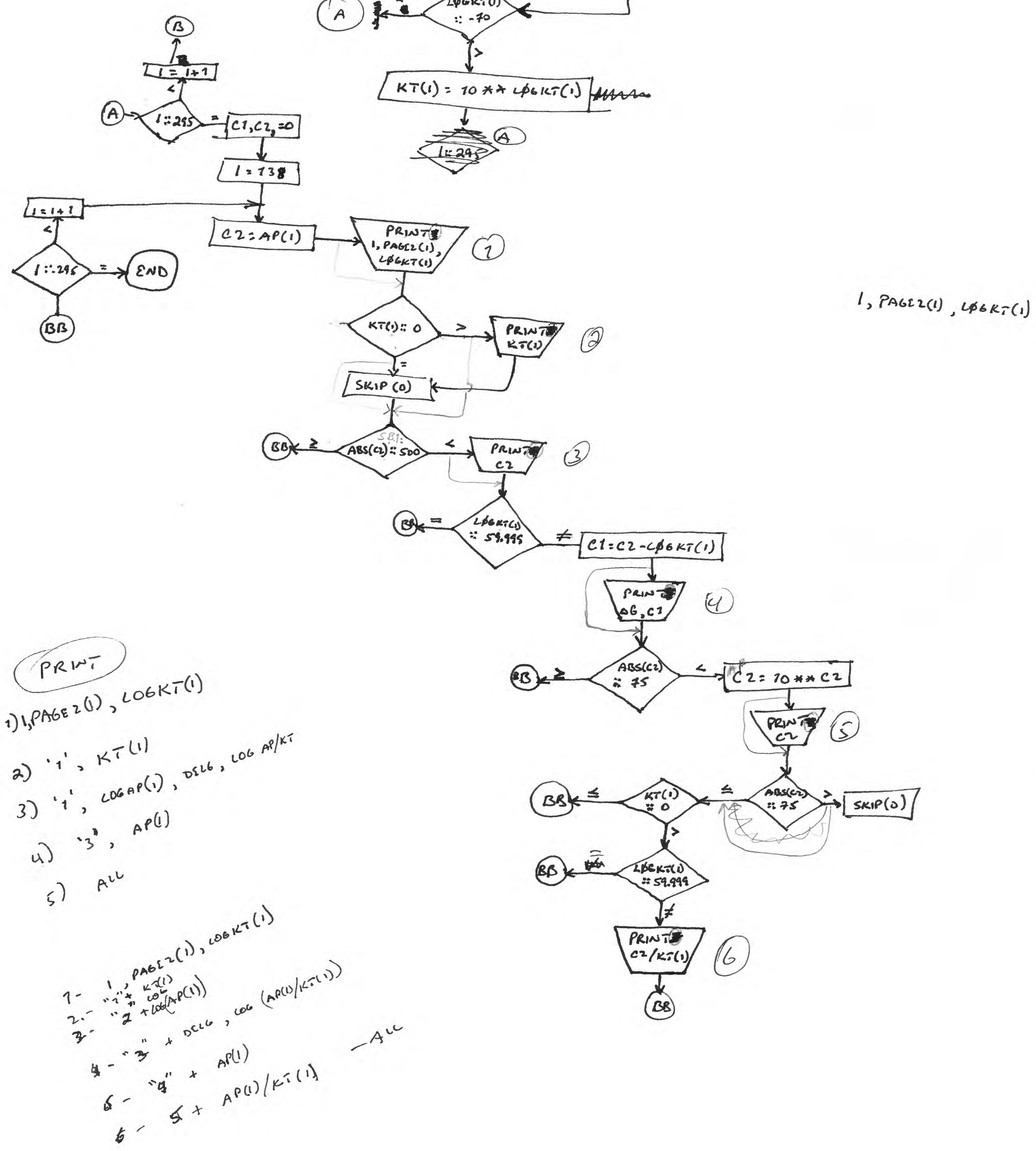




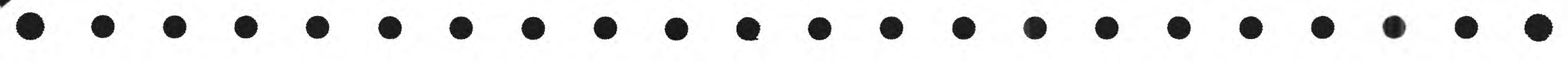

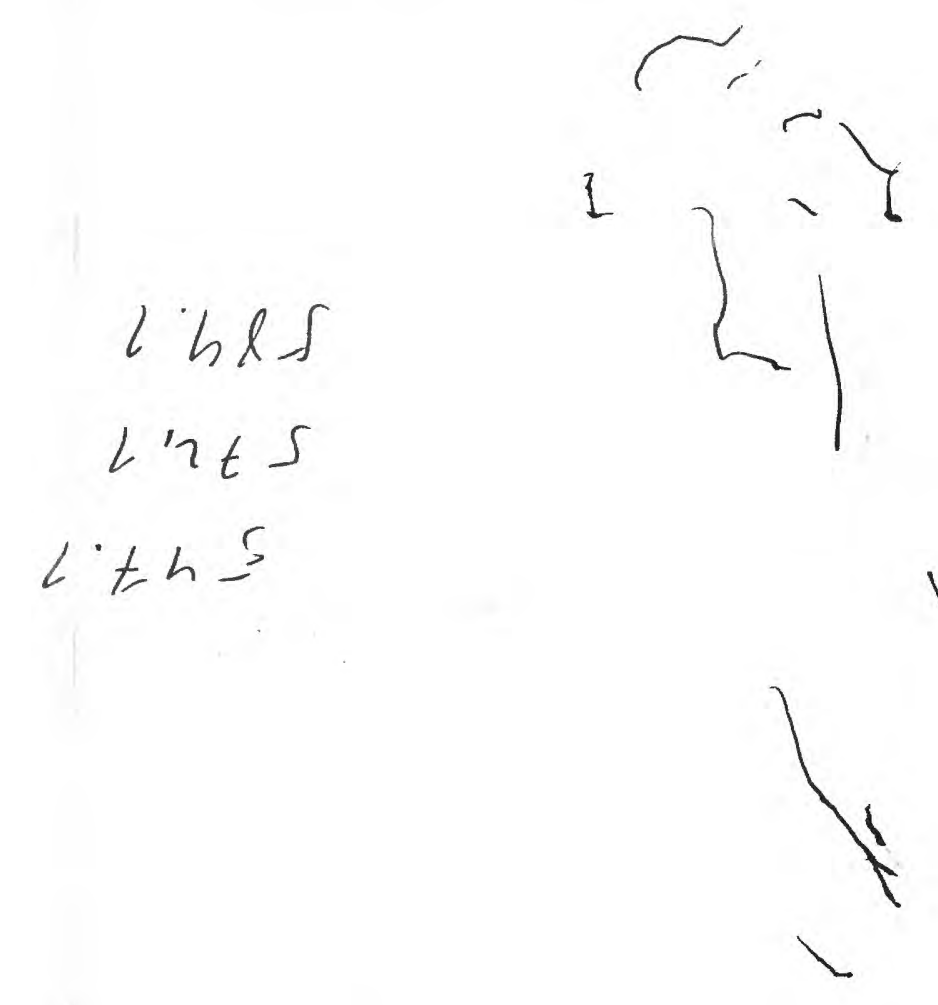

1
2
$i$
$i$
2 



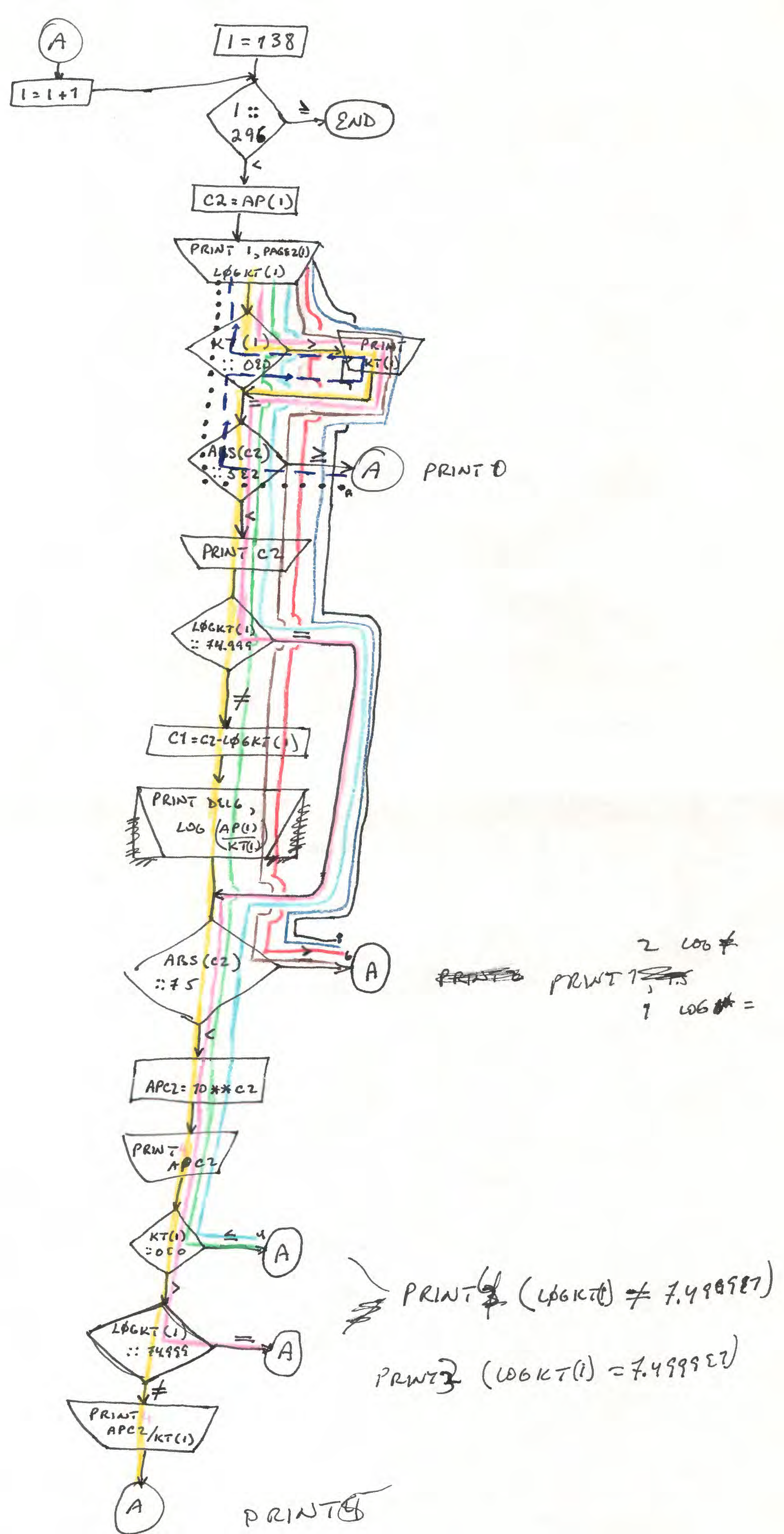


$\bullet \bullet \bullet \bullet \bullet \bullet \bullet \bullet \bullet \bullet \bullet \bullet \bullet \bullet \bullet \bullet \bullet \bullet \bullet \bullet \bullet \bullet \bullet \bullet \bullet \bullet$

$\$$ 
143. AKERMA:II

144. ALBITF L

145. ALBITE H

146. ALUNITE

147. ANALCIME

148. AidDallis I

149. A:H'DR.II

150. ANAITE:

151. APATCHLR

152. APATFLUR

153. APATHYDX

154. ARAGCNIT

155. BARITE

156. BIOT ITE

157. BO ЁMITE

158. BURNITE

159. BRUCITE

160. CA:CITE

161. CAC 2

162. CAOLIME

163. $\mathrm{CA}(\mathrm{OH}) 2$

164. CAS

165. CELESTIT

166. HHLCEDN

167. CHLOR MG

168. CRYSOCOL

169. CR.YSOTIL

170. C NNAYAR

171. C:NABMET

172. CLINENST

173. RINPTIL

174. CITRUNDUM

175. CKISTOBA

176. CIISTOBB

177. $\mathrm{CU}$

178. $\mathrm{CU} 2 \mathrm{O}$

179. CU2S

180. Cusitise

181. Cur....?

182. (1: :

$$
\begin{aligned}
& \mathrm{Ca}_{2} \mathrm{MgSi}_{2} \mathrm{O}_{7}+6 \mathrm{H}^{+}+\mathrm{H}_{2} \mathrm{O} \rightarrow 2 \mathrm{Ca}^{++}+\mathrm{Hg}^{++}+2 \mathrm{H}_{4} \mathrm{SiO}_{4} \\
& \mathrm{ViaASI} \mathrm{O}_{8}+4 \mathrm{H}^{+}+4 \mathrm{H}_{2} \mathrm{O} \rightarrow \mathrm{Na}^{+}+\mathrm{Al}^{+3}+3 \mathrm{H}_{4} \mathrm{SiO}_{4} \\
& \mathrm{NaAlSI} \mathrm{O}_{8}+4 \mathrm{H}^{+}+4 \mathrm{H}_{2} \mathrm{O} \rightarrow \mathrm{Na}^{+}+\mathrm{Al}^{+3}+3 \mathrm{H}_{4} \mathrm{SlO}_{4} \\
& \mathrm{KAl}_{3}\left(\mathrm{SO}_{4}\right)_{2} \cdot{ }^{(\mathrm{OH})_{6}} \rightarrow \mathrm{K}^{+}+3 \mathrm{Al}^{+3}+2 \mathrm{SO}_{4}^{--}+6(\mathrm{OH})^{-} \\
& \mathrm{NaAl}_{\mathrm{Si}_{2} \mathrm{O}_{6}} \quad \cdot \mathrm{H}_{2} \mathrm{O}+4 \mathrm{H}^{+}+\mathrm{H}_{2} \mathrm{O} \rightleftharpoons \mathrm{Na}^{+}+\mathrm{Al}^{+3}+2 \mathrm{H}_{4} \mathrm{SlO}_{4} \\
& \mathrm{Al}_{2} \mathrm{SiO}_{5}+6 \mathrm{H}^{+} \quad 2 \mathrm{Al}^{+3}+\mathrm{H}_{4} \mathrm{SiO}_{4}+\mathrm{H}_{2} \mathrm{O} \\
& \mathrm{CaSO}_{4} \rightleftarrows \mathrm{Ca}^{++}+\mathrm{SO}_{4}^{--} \\
& \mathrm{KFe}_{3} \mathrm{AlSi}_{3} \mathrm{O}_{10}(\mathrm{OH})_{2}+10 \mathrm{H}^{+} \rightarrow \mathrm{K}^{+}+3 \mathrm{Fe}^{++}+\mathrm{Al}^{+3}+3 \mathrm{H}_{4} \mathrm{SiO}_{4}
\end{aligned}
$$

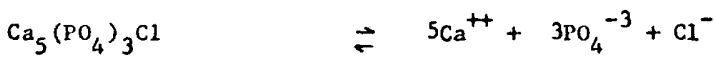

$$
\begin{aligned}
& \mathrm{Ca}_{5}\left(\mathrm{PO}_{4}\right)_{3} \mathrm{~F} \\
& \Rightarrow \quad \mathrm{Ca}^{++}+3 \mathrm{PO}_{4}^{-3}+\mathrm{F}^{-} \\
& \mathrm{Ca}_{5}\left(\mathrm{PO}_{4}\right)_{3} \mathrm{OH} \\
& \overrightarrow{5} \mathrm{Ca}^{++}+3 \mathrm{PO}_{4}^{-3}+\mathrm{OH}^{-} \\
& \mathrm{CaCO}_{3} \\
& \neq \mathrm{Ca}^{++}+\mathrm{CO}_{3}^{--} \\
& \mathrm{BaSO}_{4} \\
& \Rightarrow \mathrm{Ba}^{++}+\mathrm{SO}_{4}^{--} \\
& \mathrm{AlOOH}+3 \mathrm{H}^{+} \\
& \approx \mathrm{Al}^{+3}+2 \mathrm{H}_{2} \mathrm{O} \\
& \mathrm{Cu}_{5} \mathrm{FeS}_{4}+4 \mathrm{H}^{+} \\
& =5 \mathrm{Cu}^{+}+\mathrm{Fe}^{+3}+4 \mathrm{HS}^{-} \\
& \mathrm{Mg}(\mathrm{OH})_{2} \\
& \approx \mathrm{Mg}^{++}+2 \mathrm{OH}^{-} \\
& \mathrm{CaCO}_{3} \\
& =\mathrm{Ca}^{++}+\mathrm{CO}_{3}^{--} \\
& \rightleftharpoons \mathrm{Ca}^{++}+2 \mathrm{Cl}^{-} \\
& \rightleftharpoons \mathrm{Ca}^{++}+\mathrm{H}_{2} \mathrm{O} \\
& \mathrm{Ca}(\mathrm{OH})_{2} \\
& \mathrm{CaS}+\mathrm{H}^{+} \\
& =\mathrm{Ca}^{++}+\mathrm{Hs}^{-} \\
& \rightleftharpoons \mathrm{Sr}^{++}+\mathrm{SO}_{4}^{--}
\end{aligned}
$$$$
\text { K (2) }
$$$$
\mathrm{K}(1)
$$$$
\text { K(1) }
$$

K (Hemley and others, 1969)

$$
\begin{aligned}
& \mathrm{K}(1) \\
& \mathrm{K}(1)
\end{aligned}
$$$$
\mathrm{K}(1)
$$

K (Dick Beane, oral commun., 1972)

Truesdell Jones (unpub. data, 1972) $\mathrm{K}(3)$

$\mathrm{K}(1)$

(0)

Fournier (1973)

K (Zen, 1972)

(0)

$k(1)$

$k(1)$

$K(1)$

$k(1)$

K(1)

$k(1)$

$\mathrm{K}(1)$

(o) 
COMPUTER NO. ANO NAME

183. CUO
184. CUS
185. CUMMINGT
186. DICKITE
187. DIOPSIDE
188. NOLOMITE
189. ENSTA:TT
190. ERIONZTE
191. FAYALITE

192. FEASS

193. FECL2

194. FECL3

195. FECO3

196. FEO

197. FE203LEM

198. FE203NCH

199. FE,304

200. FEOH; 3AM

201. FES2PYR

202. FESTEOLT

203. FESMAKIN

204. FORSTERI

205. FLUORITE

206. GOETHITE

207. GIBBS AM

208. GIBBS :

209. GREEMALI

210. GREIGITE

211. GYPSUM

212. HALITE

213. HALLOYSI

214. HEULANLI

215. HGO

216. HUNT IT

217. HYDRMAGN

2i8. ILLITE

219. NAOLINIT

BEACTION

SOURCE OF DATA

$$
\begin{aligned}
& \text { CụO }+2 \mathrm{H}^{+} \\
& \rightleftharpoons \mathrm{Cu}^{++}+\mathrm{H}_{2} \mathrm{O} \\
& \mathrm{CuS}+\mathrm{H}^{+} \\
& \rightleftharpoons \mathrm{Cu}^{++}+\mathrm{HS}^{-} \\
& \mathrm{Fe}_{7} \mathrm{Si}_{8} \mathrm{O}_{22}(\mathrm{OH})_{2}+14 \mathrm{H}^{+}+8 \mathrm{H}_{2} \mathrm{O}=7 \mathrm{Fe}^{++}+8 \mathrm{H}_{4} \mathrm{SiO}_{4} \\
& \mathrm{Al}_{2} \mathrm{Si}_{2} \mathrm{O}_{5}(\mathrm{OH})_{4}+6 \mathrm{H}^{+}=2 \mathrm{Al}^{+3}+2 \mathrm{H}_{4} \mathrm{SiO}_{4}+\mathrm{H}_{2} \mathrm{O} \\
& \mathrm{CaMgSi}_{2} \mathrm{O}_{6}+4 \mathrm{H}^{+}+2 \mathrm{H}_{2} \mathrm{O}=\mathrm{Ca}^{++}+\mathrm{Mg}^{++}+2 \mathrm{H}_{4} \mathrm{SiO}_{4} \\
& \mathrm{CaMg}\left(\mathrm{CO}_{3}\right)_{2} \\
& =\mathrm{Ca}^{++}+\mathrm{Mg}^{++}+2 \mathrm{CO}_{3}^{--} \\
& \mathrm{MgSiO}_{3}+2 \mathrm{H}^{+}+\mathrm{H}_{2} \mathrm{O} \quad=\mathrm{Mg}^{++}+\mathrm{H}_{4} \mathrm{SiO}_{4} \\
& \mathrm{CaNaAl}_{3} \mathrm{Si}_{9} \mathrm{O}_{24} \cdot 9 \mathrm{H}_{2} \mathrm{O}+12 \mathrm{H}^{+}+3 \mathrm{H}_{2} \mathrm{O} \rightleftharpoons \mathrm{Ca}^{++}+\mathrm{Na}^{+}+3 \mathrm{Al}^{+3}+9 \mathrm{H}_{4} \mathrm{SiO}_{4} \\
& \mathrm{Fe}_{2} \mathrm{SiO}_{4}+4 \mathrm{H}^{+} \\
& \rightleftharpoons 2 \mathrm{Fe}^{++}+\mathrm{H}_{4} \mathrm{SiO}_{4}
\end{aligned}
$$

$\mathbf{k}(1)$

K(Lafon, 1969)

$$
\begin{aligned}
& \mathrm{FeCl}_{2} \quad \approx \mathrm{Fe}^{++}+2 \mathrm{Cl}^{-} \quad \mathrm{x}(1) \\
& \mathrm{FeCl}_{3} \quad \Rightarrow \mathrm{Fe}^{+3}+3 \mathrm{Cl}^{-} \quad \mathrm{K}(1) \\
& \mathrm{FeCO}_{3} \rightleftharpoons \mathrm{Fe}^{++}+\mathrm{CO}_{3}^{--} \text {. } \quad \text { (1) }
\end{aligned}
$$

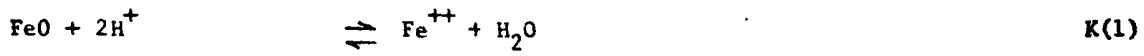

$$
\begin{aligned}
& \mathrm{Fe}_{2} \mathrm{O}_{3}+6 \mathrm{H}^{+} \quad \mathrm{F} \mathrm{Fe}^{+3}+3 \mathrm{H}_{2} \mathrm{O} \quad \mathrm{K}(1) \\
& \mathrm{Fe}_{2} \mathrm{O}_{3}+6 \mathrm{H}^{+} \quad \rightleftharpoons 2 \mathrm{Fe}^{+3}+3 \mathrm{H}_{2} \mathrm{O} \\
& \mathrm{Fe}_{3} \mathrm{O}_{4}+\mathrm{BH}^{+} \quad 2 \mathrm{Fe}^{+3}+\mathrm{Fe}^{++}+4 \mathrm{H}_{2} \mathrm{O}^{\circ} \\
& \text { (25) Langmuir (1969) } \\
& \mathrm{K}(1) \\
& \mathrm{Fe}(\mathrm{OH})_{3} \quad \mathrm{Fe}^{+3}+3 \mathrm{OH}^{-} \quad \mathrm{K}(2) \\
& 4 \mathrm{FeS}_{2}+4 \mathrm{H}_{2} \mathrm{O} \quad \rightleftarrows 4 \mathrm{Fe}^{++}+7 \mathrm{HS}^{-}+\mathrm{SO}_{4}^{--}+\mathrm{H}^{+} \quad \mathrm{K}(1) \\
& \mathrm{FeS}+\mathrm{H}^{+} \rightleftharpoons \mathrm{Fe}^{++}+\mathrm{HS}^{-} \quad \mathrm{K} \text { (1) } \\
& \mathrm{FeS}+\mathrm{H}^{+} \rightleftharpoons \mathrm{Fe}^{++}+\mathrm{HS}^{-} \text {(0) } \\
& \mathrm{Mg}_{2} \mathrm{SiO}_{4}+4 \mathrm{H}^{+} \quad \rightleftarrows 2 \mathrm{Mg}^{++}+\mathrm{H}_{4} \mathrm{SiO}_{4} \quad \mathrm{~K}(1) \\
& \mathrm{CaF}_{2} \quad \mathrm{Ca}^{++}+2 \mathrm{~F}^{-} \quad \mathrm{K}(1) \\
& \mathrm{FeOOH}+3 \mathrm{H}^{+} \quad \mathrm{Fe}+2 \mathrm{FH}_{2} \mathrm{O} \quad \mathrm{K} \text { ( Langmuir, 1971) }
\end{aligned}
$$

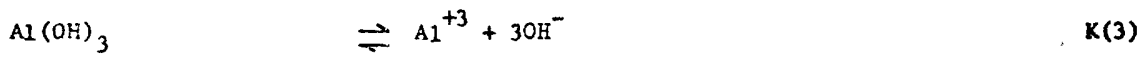

$$
\begin{aligned}
& \mathrm{Al}(\mathrm{OH})_{3} \quad \mathrm{~A} 1^{+3}+3 \mathrm{H}^{-} \quad \mathrm{K}(\mathrm{L}) \\
& \left.\mathrm{Fe}_{3} \mathrm{Si}_{2} \mathrm{O}_{5} \text { (OH) } 4+6 \mathrm{H}^{+} \longrightarrow 3 \mathrm{Fe}^{++}+2 \mathrm{H}_{4} \mathrm{SiO}_{4}+\mathrm{H}_{2} \mathrm{O} \quad \text { (25) Truesdell d Jonęs Gunpub. data, } 1972\right)
\end{aligned}
$$$$
\mathrm{Fe}_{3} \mathrm{~S}_{4}+4 \mathrm{H}^{+} \quad \rightleftarrows 2 \mathrm{Fe}^{+3}+\mathrm{Fe}^{++}+4 \mathrm{HS}^{-} \quad \text { (25) Berne: (1967) }
$$$$
\mathrm{CaSO}_{4} \cdot 2 \mathrm{H}_{2} \mathrm{O} \quad \rightleftarrows \mathrm{Ca}^{++}+\mathrm{SO}_{4}^{--}+2 \mathrm{H}_{2} \mathrm{O} \quad \mathrm{K}(2)
$$$$
\mathrm{NaCl} \quad \mathrm{Na}^{+}+\mathrm{Cl}^{-}, \mathrm{k}(1)
$$$$
\mathrm{Al}_{2} \mathrm{Si}_{2} \mathrm{O}_{5}(\mathrm{OH})_{4}+6 \mathrm{H}^{+} \Rightarrow 2 \mathrm{Al}^{+3}+2 \mathrm{H}_{4} \mathrm{SiO}_{4}+\mathrm{H}_{2} \mathrm{O} \quad \mathrm{K}(1)
$$$$
\mathrm{CaAl}_{2} \mathrm{Si}_{7} \mathrm{O}_{18} \cdot 6 \mathrm{H}_{2} \mathrm{O}+8 \mathrm{H}^{+}+4 \mathrm{H}_{2} \mathrm{O} \Rightarrow \mathrm{Ca}^{++}+7 \mathrm{H}_{4} \mathrm{SiO}_{4}+2 \mathrm{Al}^{+3} \text { (0) }
$$$$
\mathrm{HgO}+2 \mathrm{H}^{+} \quad \approx \mathrm{Hg}^{++}+\mathrm{H}_{2} \mathrm{O} \quad \mathrm{K}(1)
$$$$
\mathrm{CaM}_{3}\left(\mathrm{CO}_{3}\right)_{4} \quad \longrightarrow \mathrm{Ca}^{++}+3 \mathrm{Mg}^{++}+4 \mathrm{CO}_{3}^{--} \quad \mathrm{K}(1)
$$$$
\mathrm{MB}_{4}\left(\mathrm{CO}_{3}\right)_{3}(\mathrm{OHi})_{2} \cdot 3 \mathrm{I}_{2} \mathrm{O} \geqslant 4 \mathrm{Mg}^{++}+3 \mathrm{CO}_{3}^{--}+2(\mathrm{Oii})^{-}+3 \mathrm{HI}_{2} \mathrm{O} \quad \text { (25) Langmuir (1965) }
$$$$
{ }^{\mathrm{K}} \cdot 6^{\mathrm{Mg}} .25^{\mathrm{Al}} 2.3^{\mathrm{Si}} 3.5^{\mathrm{O}}{ }_{10}{ }^{(\mathrm{OH})} 2+8 \mathrm{H}^{+}+2 \mathrm{H}_{2} \mathrm{O} \rightleftharpoons 0.6 \mathrm{~K}^{+}+0.25 \mathrm{Kg}^{++}+2.3 \mathrm{Al}^{+3}+3.5 \mathrm{H}_{4} \mathrm{SiO}_{4} \quad \mathrm{~K}(1)
$$$$
\mathrm{Al}_{2} \mathrm{Si}_{2} \mathrm{O}_{5}(\mathrm{OH})_{4}+6 \mathrm{H}^{+} \rightleftharpoons 2 \mathrm{AL}^{+3}+2 \mathrm{H}_{4} \mathrm{SiO}_{4}+\mathrm{H}_{2} \mathrm{O} \quad \mathrm{K}(\mathrm{l})
$$ 
220. KENYAITE

:21. KYANITE

222. $\mathrm{K} 20$

223. LARNITE

224. LAUMNIIT

225. L.EUCIIE

225. LEONI:"E

227. MaGAMITE

228. MAGNESIT

225. MALACHIT

230. MAR:ALIT

231. MEIONITE

232. MERWINIT

233. MGCL2

234. MGFE 294

235. MGOPEPIC

236. MICROCLN

237. :9RRIBLIT

238. MNCl2

239. MNCO3

240. MNO

241. MNO2

242. MNS

243. MONTICEL

244. HONTC:

245. MONT K

246. SolNT rio

247. YONIHA

248. MONTCANA

249. MONTSEAW

250. MORUEAIT

251. NUSCOVIT

252. NA2O

253. Na2Sứ

254. NA.HCOL. IT

255. NATRON

256. MATKTHRH

257. NHPIETI

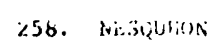

259. Nicura!"

200. 1'.
$\mathrm{NaSi}_{11}{ }^{0} 20.5^{(\mathrm{OHI})_{4}} \cdot 3 \mathrm{H}_{2} \mathrm{O}+\mathrm{H}^{+}+16.5 \mathrm{H}_{2} \mathrm{O} \rightleftharpoons \mathrm{Na}^{+}+11 \mathrm{H}_{4} \mathrm{SlO}_{4}$

$$
\mathrm{Al}_{2} \mathrm{SiO}_{5}+6 \mathrm{Ii}^{+} \rightleftharpoons 2 \mathrm{Al}^{+3}+\mathrm{H}_{4} \mathrm{SlO}_{4}+\mathrm{H}_{2} \mathrm{O}
$$

(25) Brlcker (1969)

$\mathrm{K}_{2} \mathrm{O}+2 \mathrm{H}^{+}$

$\rightleftharpoons 2 \mathrm{~K}^{+}+\mathrm{H}_{2} \mathrm{O}$

$\mathrm{Ca}_{2} \mathrm{SiO}_{4}+4 \mathrm{H}^{+}$

$\Rightarrow 2 \mathrm{Ca}+\mathrm{H}_{4} \mathrm{SiO}_{4}$

$\mathrm{CaAl}_{2} \mathrm{SiO}_{4} \mathrm{O}_{12} \cdot 4 \mathrm{H}_{2} \mathrm{O}+8 \mathrm{H}^{+} \rightleftharpoons \mathrm{Ca}^{++}+2 \mathrm{Al}^{+3}+4 \mathrm{H}_{4} \mathrm{SiO}_{4}$

$\mathrm{KAl} \mathrm{Si}_{2} \mathrm{O}_{6}+4 \mathrm{H}^{+}+2 \mathrm{H}_{2} \mathrm{O} \rightleftharpoons \mathrm{K}^{+}+\mathrm{Al}^{+3}+2 \mathrm{H}_{4} \mathrm{SiO}_{4}$

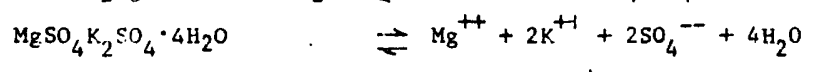

$\mathrm{NaSi}_{7}\left(\mathrm{O}_{13} \mathrm{(OH}\right)_{3} \cdot 3 \mathrm{H}_{2} \mathrm{O}+\mathrm{H}^{+}+9 \mathrm{H}_{2} \mathrm{O} \rightleftharpoons \mathrm{Na}^{+}+7 \mathrm{H}_{4} \mathrm{SiO}_{4}$

$\mathrm{MgCO}_{3}$

$\rightleftharpoons \mathrm{Mg}^{++}+\mathrm{CO}_{3}^{--}$

$\mathrm{K}(1)$

$K(1)$

$k(1)$

K (Zen, 1972)

$K(1)$

(0)

(25) Bricker (1969)

$\mathrm{Cu}_{2} \mathrm{CO}_{3}(\mathrm{OH:})_{2}$

$\rightleftharpoons 2 \mathrm{Cu}^{++}+\mathrm{CO}_{3}^{--}+2 \mathrm{OH}^{-}$

$\mathrm{K}(1)$

$\left(\mathrm{NaAlSI}_{3} \mathrm{O}_{8}\right)_{3} \cdot \mathrm{NaCl}+12 \mathrm{H}^{+}+12 \mathrm{H}_{2} \mathrm{O} \rightleftarrows 4 \mathrm{Na}^{+}+3 \mathrm{Al}^{+3}+9 \mathrm{H}_{4} \mathrm{SiO}_{4}+\mathrm{Cl}^{-}$

$\left(\mathrm{CaAl}_{2} \mathrm{Si}_{2} 08\right)_{3} \cdot \mathrm{CaCO}_{3}+24 \mathrm{H}^{+} \rightleftharpoons 4 \mathrm{Ca}^{++}+6 \mathrm{Al}^{+3}+6 \mathrm{H}_{4} \mathrm{SiO}_{4}+\mathrm{CO}_{3}^{--}$

$\mathrm{K}(3)$

PATHI, Helgeson and others(1970)

$\mathrm{Ca}_{3} \mathrm{MgSi}_{2} \mathrm{O}_{8}+8 \mathrm{H}^{+}$

$\Rightarrow 3 \mathrm{Ca}^{++}+\mathrm{Mg}^{++}+2 \mathrm{H}_{4} \mathrm{~S}_{4} \mathrm{O}_{4}$

$\mathrm{MgCl}_{2}$

$\geqslant \mathrm{Mg}^{++}+2 \mathrm{Cl}^{-}$

K(1)

$\mathrm{MgFe}_{2} \mathrm{O}_{4}+8 \mathrm{H}^{+}$

$\Rightarrow \mathrm{Mg}^{++}+2 \mathrm{Fe}^{+3}+4 \mathrm{H}_{2} \mathrm{O}$

$k(1)$

$\mathrm{MgO}+2 \mathrm{H}^{+}$

$\neq \mathrm{Mg}^{++}+\mathrm{H}_{2} \mathrm{O}$

$k(2)$

$\mathrm{KAlSi}_{3} \mathrm{O}_{8}+4 \mathrm{H}^{+}+4 \mathrm{H}_{2} \mathrm{O}$

$\gtrless \mathrm{K}^{+}+\mathrm{Al}^{+3}+3 \mathrm{H}_{4} \mathrm{SiO}_{4}$.

$\because \mathrm{B}_{2} \mathrm{Sn}_{4} \cdot ? 2 \mathrm{H}, 0$

$\Rightarrow 2 \mathrm{Na}^{+}+\mathrm{SO}_{4}^{--}+10 \mathrm{H}_{2} \mathrm{O}$

$\mathrm{K}(1)$

$\mathrm{MnCl}_{2}$

$\mathrm{MnCO}_{3}$

$\rightleftharpoons \mathrm{Mn}^{++}+2 \mathrm{Cl}^{-}$

$R(1)$

$K(4)$

$\mathrm{K}(1)$

$\mathrm{k}(1)$

$\mathrm{MnO}+2 \mathrm{H}^{+}$

$\rightleftharpoons \mathrm{Mn}^{++}+\mathrm{CO}_{3}^{--}$

$k(1)$

$\mathrm{MnO}_{2}+4 \mathrm{H}^{+}+\mathrm{Hn}^{++}$

$\rightleftarrows \mathrm{Mn}^{++}+\mathrm{H}_{2} \mathrm{O}$

$\mathrm{Mns}+\mathrm{H}^{+}$

$\rightleftharpoons 2 \mathrm{Mn}^{+3}+2 \mathrm{H}_{2} \mathrm{O}$

PATHI, Helgeson and others(1970)

$\mathrm{CaMgSiO}_{4}+4 \mathrm{H}^{+}$

$\rightleftharpoons \mathrm{Mn}^{++}+\mathrm{HS}^{-}$

$R(1)$

$\rightleftharpoons \mathrm{Ca}^{++}+\mathrm{Mg}^{++}+\mathrm{H}_{4} \mathrm{SiO}_{4}$

$k(1)$

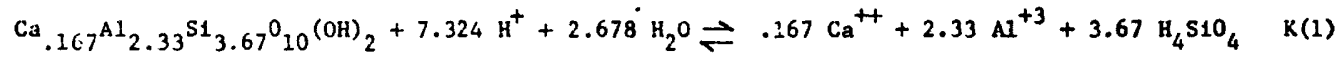

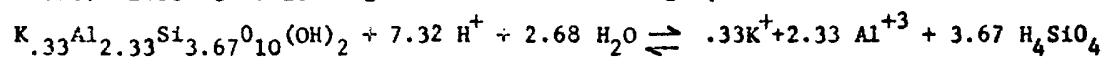

$K(1)$

$\mathrm{Mg}_{1} 167^{\mathrm{Al}} 2.33^{\mathrm{SI}_{3} .67^{\mathrm{O}} 10^{(\mathrm{OH})_{2}}+7.324 \mathrm{H}^{+}+2.678 \mathrm{H}_{2} \mathrm{O}} \rightleftharpoons .167 \mathrm{Mg}^{++}+2.33 \mathrm{Al}^{+3}+3.67 \mathrm{H}_{4} \mathrm{S1O}_{4} \quad \mathrm{~K}(1)$

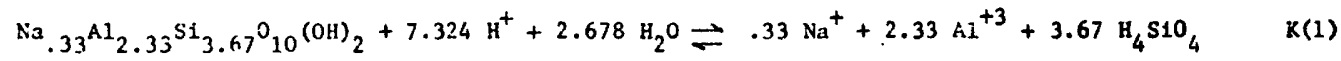

(0)

(0)

(0)

$\mathrm{CaAl}_{2} \mathrm{Si}_{10} 0_{24} \cdot 7 \mathrm{H}_{2} \mathrm{O}+8 \mathrm{H}^{+}+9 \mathrm{H}_{2} \mathrm{O} \rightleftharpoons \mathrm{Ca}^{++}+2 \mathrm{Al}^{+3}+1 \mathrm{OH}_{4} \mathrm{SiO}_{4}$

$K($ Zen, 1372)

$\mathrm{KAll}_{3} \mathrm{Si}_{3} \mathrm{O}_{10}(\mathrm{OH})_{2}+10 \mathrm{H}^{+} \rightleftharpoons \mathrm{K}^{+}+3 \mathrm{NI}^{+3}+3 \mathrm{H}_{4} \mathrm{SHO}_{4}$

$\mathrm{K}(1)$

$\mathrm{Nia}_{2} \mathrm{O}+2 \mathrm{H}^{+}$

$\Longrightarrow 2 \mathrm{Na}^{+}+\mathrm{H}_{2} \mathrm{O}$

$K(1)$

$\mathrm{Na}_{2} \mathrm{SO}_{4}$

$\Rightarrow 2 \mathrm{Nn}^{+}+\mathrm{SO}_{4}^{--}$

$\mathrm{K}(3)$

$\mathrm{Na}_{3}$

$\rightleftarrows \mathrm{Na}^{+}+\mathrm{HCO}_{3}^{-}$

$k(3)$

$\mathrm{Na}_{2} \mathrm{CO}_{3} \cdot 1 \mathrm{OH}_{2} \mathrm{O}$

$\rightleftharpoons \quad 2 \mathrm{~K}^{+}+\mathrm{CO}_{3}^{--}+1 \mathrm{OH}_{2} \mathrm{O}$

$k(3)$

$\mathrm{lia}_{2} \mathrm{COO}_{3} \cdot \mathrm{H}_{2} \mathrm{O}$

$\Rightarrow 2 \mathrm{Na}^{+}+\mathrm{Cu}_{3}^{--}+\mathrm{I}_{2} \mathrm{O}$

$x(2)$

$\mathrm{NaAl} \mathrm{SiO}_{4}+4 \mathrm{HI}^{+}$

$\because \quad \mathrm{Ail}^{\mathrm{r}}+\mathrm{Al}^{+3}+\mathrm{H}_{4} \mathrm{SiO}_{4}$

$k(3)$

$\because g \operatorname{Cos}_{3} \cdot 3 \mathrm{Hi}_{2} \mathrm{O}$

$\Rightarrow \mathrm{Mi}^{+-4}+\mathrm{CO}_{3}^{--}+3 \mathrm{H}_{2} \mathrm{O}$

(0) 


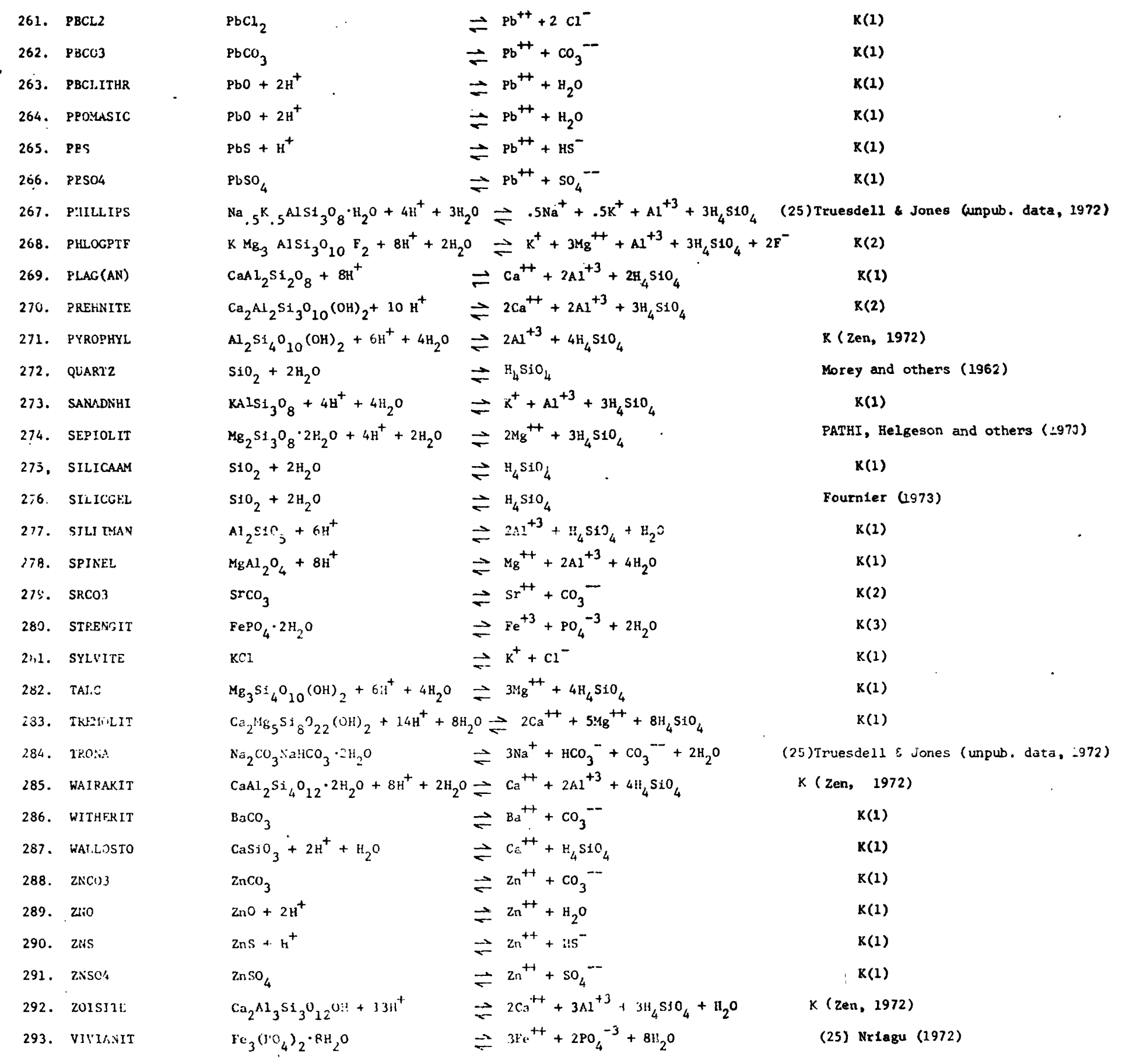

294. Blank

2y5. Blank 
Table 1.--Li-t of the agueous complexes and minerals used in SOLMIEQ. The source

of data for the $10 \mathrm{~g}$ (K.T) wilues of the given reactions is indicated--Continued

COMPUTER NO. AND NAME

C - OXIDATION-REDUCTION REACTION

\begin{tabular}{|c|c|c|c|c|}
\hline 236. & FE2 TO FE3 & $\mathrm{Fe}^{++}$ & $\Rightarrow \mathrm{Fe}^{+3}+\mathrm{e}^{-}$ & $K(1)$ \\
\hline 297 . & $\mathrm{CU}, \cdot \mathrm{O} \mathrm{CU}_{2}$ & $\mathrm{Cu}^{+}$ & $\rightarrow \mathrm{Cu}^{++}+\mathrm{e}^{-}$ & $K(1)$ \\
\hline 298. & $\mathrm{HC} 222 \mathrm{HG} 2$ & $\mathrm{Hg}_{2}+$ & $\rightleftarrows 2 \mathrm{Hg}^{++}+2 \mathrm{e}^{-}$ & $k(1)$ \\
\hline & MN2 TO MN3 & $\mathrm{Mn}^{++}$ & $\rightarrow \mathrm{Mn}^{+3}+\mathrm{e}^{-}$ & $K(1)$ \\
\hline
\end{tabular}

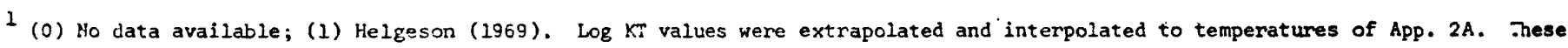

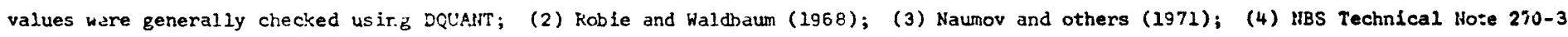

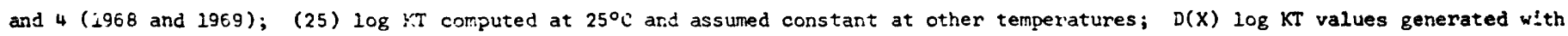

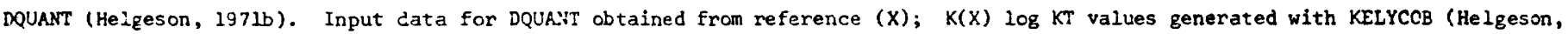

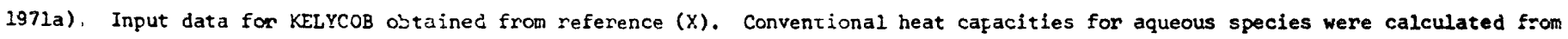
aver.ge heat capacities (Cobble, 1964 ; Helgeson, unpub. data).

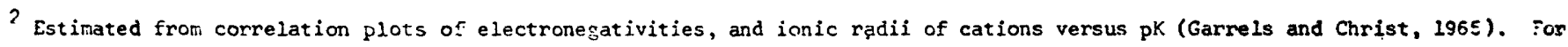
$\mathrm{SrSO}_{4}, \Delta G^{\circ}$ from Lieser (1965), $\mathrm{S}^{\circ}$ estimates from correlation plots (Helge6on, 1969 ).

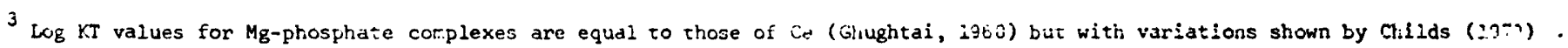
at $51^{\circ} \mathrm{C}$.

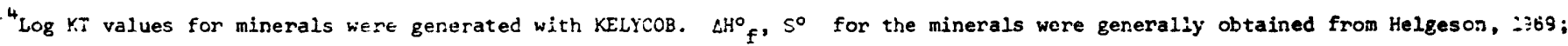

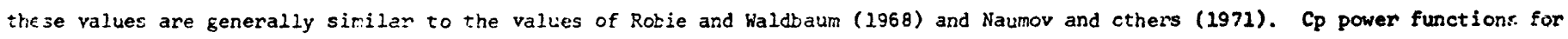
$m_{1}$ iserals wert obtained from kelley (1960, or (3), or estimated (see text). 
Activity coefficients

In this program the activity coefficients $(\gamma)$ for the charged aqueous species are computed using the $B^{\circ}$ method (Lewis and Randall, 1961; Helgeson, 1969).

$$
\log \gamma_{i}(T, I)=\frac{-A(T) v_{i}^{2} I^{1 / 2}}{1+a_{i}^{o} B(T) I^{1 / 2}}+B^{\cdot}(T) I
$$

where

$a_{i}^{0} \quad$ is the distance of the nearest approach of ions in solution,

$A(T)$ is a molal Debye-Hückel coefficient at temperature $T$,

$B(T)$ is a molal Debye-Htickel coefficient at temperature $T$,

$v_{i}$ is the charge of the ith ion,

I is the ionic strength, and

$B^{\cdot} \quad$ is a deviation function. 
The Debye-Huckel coefficients $A$ and $B$ are given by

$$
A(T)=\frac{1.8246 \times 10^{6}(\rho(T))^{1 / 2}}{(\varepsilon(T) T)^{3 / 2}}
$$

end

$$
B(T)=\frac{50.29 \times 10^{8}(\rho(T))^{1 / 2}}{(\varepsilon(T) T)^{1 / 2}}
$$

where $\rho$ and $\varepsilon$ are the density and the dielectric constant of water at temperature $T$.

The ionic strength (I) of a given solution is given by

$$
I \equiv I / 2 \sum_{i} m_{i} v_{i}^{2}
$$

The density of water is computed from the equations of Keenan and Keyes (1936, p. 21). The dielectric constant of water is salculated to $100^{\circ} \mathrm{C}$ from the equation of Wyman and Ingalls as cited by Harned and Owen (1958, p. 159); it is calculated at higher temperatures from the function of Akerlof and Oshry (1950). (See ippendix 1.)

The $a^{\circ}$ values used (App. 2B) are from Kielland (1937). Arbitrary $\mathrm{a}^{\circ}$ values of $4.0,5: 0$, and 6.0 were assigned respectively to those monovalent, divalent and trivalent species in solution not reported by Kielland. 
The values for the deviation function, $B^{*}$, reported in this program as a function of temperature (App. 2D) are from Helgeson :1969). SOLMNEQ computes $B^{*}$ by linear interpolation of the values in Appendix 2D. This method has been discussed in detail by Helgeson (1969). The $B^{\cdot}$ values used in this program are for NaCl solutions, a close approximation for the majority of natural waters. The presence of appreciable amounts of divalent and trivalent cations and anions in solution with their higher degree of hydration will make the $\gamma_{i}$ obtained slightly lower than the true values.

The activity coefficients of all neutral species are assumed Equal to the activity coefficients of dissolved $\mathrm{CO}_{2}$ in $\mathrm{NaCl}$ solutions (Helgeson, 1967). SOLMNEC computes $\gamma_{\mathrm{CO}_{2}}$ at the temperature and ionic strength (up to 3 molal) of the solution by linear interpolation of $\gamma_{\mathrm{CO}_{2}}$ values as a function of temperature and ionic strength of an equivalent solution (App. 2C after Helgeson, 1969). Helgeson computed $\gamma_{\mathrm{CO}_{2}}$ from Ellis and Golding (1963) using

$$
r_{\mathrm{CO}_{2}}(\mathrm{~T})=\mathrm{k}_{\mathrm{m}} / \mathrm{k}
$$

where $k$ and $k_{m}$ are the Henry's law coefficients in pure water and in a sodium chloride solution of molality, $\mathrm{m}$, at temperature $\mathrm{T}$. SOLMNEQ has an option by which the activity coefficients of the : aeutral species may be given as unity. 
Equilibrium constants

The equilibrium constant $(K)$ of a reaction such as reaction ( $I$ ) is given by:

$$
k_{\text {albite }}=\frac{a_{\mathrm{Na}^{+}} \cdot a_{\mathrm{AI}^{+}} \cdot\left(a_{\left.\mathrm{H}_{4} \mathrm{SiO}_{4}\right)^{3}}\right.}{a_{\mathrm{alb}} \cdot\left(a_{\mathrm{H}^{+}}\right)^{4} \cdot\left(a_{\mathrm{H}_{2} \mathrm{O}}\right)^{4}}
$$

where $a_{i}$ is the activity of the $i$ th species at equilibrium.

The equilibrium constants for the reactions shown on table 1 are funched as part of the object deck. The $K(T)$ values reported $\therefore$ App. 2A) at intervals of $25^{\circ} \mathrm{C}$ from $0-200^{\circ} \mathrm{C}$ and at intervals of $50^{\circ} \mathrm{C}$ from $200-350^{\circ} \mathrm{C}$ were computed assuming a constant pressure of 1 atmosphere. Pressures normally encountered in natural systems will these not significally affect/computations (Helgeson, 1969). The equilibrium constants were obtained by the following methods, which are listed in decreasing order of reliability:

1. Reported experimental data (solubility, free energy, and other data) over the temperature range considered in this program.

2. Computed using KELYCOB (Program No. 0802 D/E, Helgeson, 1971a). KELYCOB computes the equilibrium constants as well as the standard entropies, enthalpies, free energies, and heat capacities of a given reaction $\left(\log K_{r}, \Delta S_{r}^{\circ}, \Delta H_{r}^{\circ}, \Delta G_{r}^{\circ}\right.$, and $\Delta=\operatorname{Delta}$ $\left.\Delta \mathrm{C}_{\mathrm{p}, \mathrm{r}}^{\mathrm{o}}{ }\right)$ as a function of temperature and pressure. The Maier-Kelley $\left(a+b T+\mathrm{cT}^{-2}\right.$, Kelley, 1960) heat capacity power functions, the standard enthalpies of formation 
$\left(\Delta \mathrm{H}_{f}^{\circ}\right)$ and the standard entropies $\left(\mathrm{S}_{i}^{\circ}\right)$ of all the components involved are used as input to this program. KELYCOB computes the $K(T)$ values from an integrated form of the Van't Hoff's equation (Helgeson, 1969).

$\log K(T)=\log K_{298.15}-\frac{\Delta \mathrm{H}^{\circ} r}{2.303 \mathrm{R}}\left(\frac{1}{T}-\frac{1}{298.15}\right)-\frac{1}{2.303 R T}$

$$
\int_{298.15}^{T} \Delta C_{p, r}^{\circ}(T) d T+\frac{1}{2.303 R} \int_{298.15}^{T} \Delta C_{p, r}^{o}(T) d \ln T
$$

KELYCOB was used to generate $\log \mathrm{K}$ values at $25^{\circ} \mathrm{C}$ intervals from $0^{\circ} \mathrm{C}$ to $350^{\circ} \mathrm{C}$ for most of the hydrolysis reactions reported on table 1 . A number of $\log K$ values for the dissociation reactions of aqueous complexes were also obtained by this method. 
The heat capacity power function for many minerals reported in this program are not known. These were approximated by summing up the heat capacity power functions for the oxides. Ice ( $9.0 \mathrm{Cal}$ mole $\left.\mathrm{edeg}^{-1}\right)$ was used to represent $\mathrm{H}_{2} \mathrm{O}$ in these approximations (Helgeson, 1969).

3. Computed using DQUANT (Program No. 0405 AR, Helgeson, 1971b). This program requires only that $\Delta H_{r}^{\circ}\left(T_{r}\right)$ and $\Delta S_{r}^{\circ}\left(T_{r}\right)$ be known; it was used where no heat capacity data of any kind were available for one or more of the species involved in the reaction. This last condition covers most of the aqueous reactions reported on table 1 . DQUANT computes $K(T)$ values by evaluating (Helgeson, 1967)

$\log K(T)=\frac{\Delta S_{r}^{\circ}\left(T_{r}\right)}{2.303 R T}\left[T_{r}-\frac{\theta}{W}(1-\exp [\exp (b+a T)\right.$

$$
\left.\left.\left.-c+\left(T-T_{r}\right) / \theta\right]\right)\right]-\frac{\Delta H_{r}^{\circ}\left(T_{r}\right)}{2.303 R T}
$$

where

$\theta, w, a, b$, and $c$ are temperature independent constants characteristic of the solvent, $\mathrm{R}$ is the gas constant. 
DQUANT assumes that $\Delta \mathrm{C}_{\mathrm{P}, \mathrm{r}}^{\circ}$ changes monotonically but nonlinearly with temperature. Dissociation constants computed from this program are often much closer approximations of actual dissociation constants at higher temperature than those computed assuming $\Delta \mathrm{C}_{\mathrm{p}, \mathrm{r}}^{\circ}(\mathrm{T})=0$ or $\Delta \mathrm{C}_{\mathrm{p}, \mathrm{r}}^{\circ}(\mathrm{T})=$ a constant (Helgeson, 1969). $K(T)$ values obtained with DQUANT are reasonable approximations only to $\sim 200^{\circ} \mathrm{C}$.

A correction factor was applied to some of the $K(T)$ values generated with DQUANT at temperatures higher than $200^{\circ} \mathrm{C}$. These factors were applied only to those complexes where experimental values for similar species are available. Even with the application of these correction factors, the errors involved in the values of $K(T)$ at temperatures higher than $200^{\circ} \mathrm{C}$ are large; this introduces large uncertainties in computations carried out with SOLMNEQ at temperatures higher than $\sim 200^{\circ} \mathrm{C}$.

4. Reported experimental data over a restricted temperature range which were extrapolated to cover the temperature range considered. Some $k$ values are known or could only be calculated at $25^{\circ} \mathrm{C}$; these have been assumed constant over the temperature range of the program. 
5. No $K(T)$ values could be obtained for a number of minerals and aqueous species incorporated in SOLMNEQ. A dummy value of $\log \mathrm{K}$ equal to 999.99 is used for these minerals and species. This value is so high that the species and minerals involved do not affect the results obtained with SOLMNEQ.

Values of $\log \mathrm{K}$ for aqueous complexes and minerals at any desired temperature can be computed from data in Appendix 2A by the subroutine (TLUV) (P. C. Doherty, oral commun., 1972). The interpolation of the $\log \mathrm{K}$ values (see listing, App. 1 ) is by:

$$
y=a+b x+c x^{2}+d x^{3}
$$

where

$\mathrm{X}$ is the independent variable (= the reported values of $\log \mathrm{K}$ at the specified temperatures),

$\mathrm{Y}$ is the dependent variable ( = the interpolated value of $\log \mathrm{K}$ at the sample temperature), and

$a, b, c$, and $d$ are constants.

This subroutine is more than adequate to interpolate the $\log \mathrm{K}$ values between the reported intervals $\left(25^{\circ} \mathrm{C}\right.$ from $0^{\circ} \mathrm{C}-200^{\circ} \mathrm{C}$ and $50^{\circ} \mathrm{C}$ from $200-350^{\circ} \mathrm{C}$ ) 
Oxidation-reduction reactions

The distribution of $\mathrm{Fe}^{+3}, \mathrm{Cu}^{++}, \mathrm{Hg}^{++}$, and $\mathrm{Mn}^{+3}$ in SOLMNEQ may be computed using equations involving electron transfer reactions such as

$$
\mathrm{Fe}^{++}=\mathrm{Fe}^{+3}+\mathrm{e}^{-}
$$

where $e^{-}$represents an electron. The concentration of $\mathrm{Fe}^{+3}\left(\mathrm{~m}_{\mathrm{Fe}}+3\right)$ may be calculated from the following equation if the Eh of the solution and $\mathrm{m}_{\mathrm{Fe}}{ }^{++}$are known:

$$
E h(T)=E^{\circ}(T)+\frac{R T}{n F} \ln \frac{m_{F^{+3}} \cdot \gamma_{\mathrm{Fe}+3}}{m_{\mathrm{Fe}^{++}} \cdot \gamma_{\mathrm{Fe}^{++}}}
$$

where

Eh(T) is the oxidation potential at the measured temperature referred to the hydrogen half cell,

$E^{\circ} \quad$ is the potential of the half cell in which all reactants and products are in their standard states,

$\mathrm{n}$ is the number of electrons (e) involved; it is equal to unity for reaction (13), and

F is the Faraday constant.

$$
E^{\circ}=\frac{\Delta G_{r}^{\circ}(T)}{n F}
$$


The standard free energies for the four oxidation-reduction reactions $\left(\Delta G_{r}^{\circ} 296,297,298\right.$, and 299) at the same temperatures as for $\log \mathrm{K}$ are included in Appendix 2A. They are interpolated to the specified temperature of the sample by Lagrange subroutine (TLUV). SOLMNEQ will compute the Eh of the sample at the desired temperature, if necessary, from the Emf of the Eh cell including the Calomel reference electrode (EHMC) or from the Emf of the Eh cell calibrated using Zobell's solution (EMFZSCE). For a more detailed discussion of the theory of Eh and its field measurement and reduction see Barnes and Back (1964), Barnes and Clarke (1969), and Garrels and Christ (1965).

Computations based on measured Eh have been kept to a minimum in this program because Barnes and Clarke (1969) showed that the measured Eh is quantitatively related only to the behavior of iron species. Distribution of species in solution

The distrilution of species in the aqueous solution is computed from the reported chemical analysis of the water sample together with field measurements of its temperature, $\mathrm{pH}$, and $\mathrm{Eh}$. The interpolated dissociation constants of the aqueous complexes $\left(K_{d i s s}\right)$ and the computed activity coefficients $(\gamma)$ are also utilized in these computations. 
The chemical analysis may contain the total concentrations of all or part of the following list of elements and ions: $\mathrm{Ca}, \mathrm{Mg}, \mathrm{Na}, \mathrm{K}, \mathrm{Cl}$ $\mathrm{SO}_{4}, \mathrm{HCO}_{3}, \mathrm{SiO}_{2}, \mathrm{Ag}, \mathrm{Al}, \mathrm{Ba}, \mathrm{Cu}, \mathrm{Fe}, \mathrm{Hg}, \mathrm{Li}, \mathrm{Mn}, \mathrm{Pb}, \mathrm{Sr}, \mathrm{Zn}, \mathrm{As}(\mathrm{OH})_{4}$, $\mathrm{PO}_{4}, \mathrm{~F}, \mathrm{H}_{3} \mathrm{BO}_{3}, \mathrm{NH}_{3}, \mathrm{H}_{2} \mathrm{~S}, \mathrm{CO}_{3}, / \mathrm{NO}_{3}$. It is not necessary to distribute the alkalinity of the sample between $\mathrm{HCO}_{3}$ and $\mathrm{CO}_{3}$; SOLMNEQ computes the concentration of these and other species contributing to the reported alkalinity.

The concentration units, for the purpose of this program, may be in ppm (parts per million) or mg/l (milligrams/liter) or moles/l (moles/liter) or meq/I (millequivalent/liter). The computations in SOLMNEQ are carried out after converting the concentration units reported to molalities. 
The distribution of species in the aqueous phase is computed using mass action reactions for all the aqueous complexes reported in table $I$, oxidation-reduction reactions, and mass balance relationships. The mass balance relationships are of the type

$$
m_{i, t}=\sum_{i} n_{i} m_{i}
$$

where

$$
\begin{aligned}
& \mathrm{m}_{i, t} \text { is the total reported or computed molality of the } i \text { th } \\
& \text { ion (for example, total molality of } \mathrm{Ca} \text { ), } \\
& \sum_{i} \mathrm{n}_{i} \mathrm{~m}_{i} \text { is the summation of the molalities of } \mathrm{Ca}^{++} \text {and all the } \\
& \text { aqueous complexes containing } \mathrm{Ca} \text { (for example, } \mathrm{CaCO}_{3(\mathrm{aq})} \\
& \text { CaHCO}_{3}^{-}, / \mathrm{CaSO}_{4(\mathrm{aq})} \text { ), and } \\
& \mathrm{n}_{i} \text { is the number of molecules of (i) appearing in the } \\
& \text { aqueous complex. }
\end{aligned}
$$

For a more detailed and specific examination of distribution of species see the listing of SOLMNEQ (APp. 1).

Iteration cycles are used to solve for the distribution of carbonate, sulphate, fluoride, phosphate, and chloride species. The iteration' cycles are carried out whenever the computed $m_{i, t}$ (equation 16) of any of these five ligands differs by more than 0.5 percent from their analyzed values. Most water samples will probably converge to meet the above requirement within about 20 iterative cycles. The cutoff number in SOLMNEQ is 100 cycles. 
Gibbs free energy functions

The Gibbs free energy for many hydrolysis reactions in natural systems may be obtained (Garrels and Christ, 1965; Barnes and Clarke, 1969) from

$$
\Delta G_{r}=-R T \text { In } Q
$$

where $\Delta G_{r}$ is the Gibbs free energy of reaction and $Q$ is the reaction quotient. $Q$ is equal to the activity product (AP) and is given for reaction (1) by

$$
Q=A P=\frac{\bar{a}_{N^{+}} \cdot \bar{a}_{A I+3} \cdot \bar{a}_{H_{4} S_{4}}}{\left(\bar{a}_{H^{+}}\right)^{4} \cdot\left(\bar{a}_{H_{2} O}\right)^{4} \cdot \bar{a}_{A I b}} .
$$

where $(\bar{a})$ is the actual activity of the species in the given solution at the specified temperature and pressure. The value of $\bar{a}_{A I b}$. is assumed to be unity. 
The Gibbs free energy difference between the actual and equilibrium states is given by

$$
\Delta G_{\text {diff }}=R T \text { In }(Q / K)
$$

All the reactions used in SOLMNEQ (table 1) have the solid on the left side of the reaction equation. As a consequence, the following relations hold:

$$
\Delta G_{\text {diff }}<0
$$

The reaction tends to proceed spontaneously from left to right. The solid cannot precipitate from this solution because of undersaturation.

$$
G_{\text {diff }}>0
$$

The reaction tends to proceed spontaneously from right to left. The solid cannot dissolve in the solution because of supersaturation.

$$
G_{\text {diff }}=0
$$

The reaction is at equilibrium and neither dissolution nor precipitation should take place. 
The fact that the free energy difference of a given reaction $\left(\Delta G_{\text {diff }}\right)$ indicates that it should proceed from left to right or vice versa, does not mean that the reaction will indeed proceed in the specified direction. The only definitive statements that can be made are that the solution is supersaturated, saturated or undersaturated with respect to the solid. Evaluation of this type should not, by themselves alone, be interpreted to indicate presence or absence of specific mineral species. It is possible for a given solution to be supersaturated (unstable but persistent condition) with respect to a mineral by a number of kilocalories without precipitation (Bames and Clarke, 1969). The computation of Gibbs free energy difference for minerals may be a useful guide for application of methods of identifying mineral species expected to be present in the system under study. 


\section{INPUT}

Input to SOLMNEQ consists of fixed (card Nos. I through 6) and optional (card Nos. 7 through 9) data as follows:

Card No.

Data

Format

1 Sample description (may be blank)

$A(80)$

$2 \operatorname{TEMP}\left(\right.$ temp. in $^{\circ} \mathrm{C}$ ), PH, EHM (Measured Eh $E(6,1), X(1)$, in volts if available; otherwise put $E(6,2), X(1)$, 9.000 EO), and FLAG for concentration $E(8,3), X(1)$, units ( $P P M$ or $M G / L$ or $M O L / L$ or $M E Q / L) . \quad A(5)$

3 Total concentration of $\mathrm{Ca}, \mathrm{Mg}, \mathrm{Na}, \mathrm{K}, \mathrm{Cl}, \quad 8(\mathrm{E}(8,3), \mathrm{X}(1))$ $\mathrm{SO}_{4}, \mathrm{HCO}_{3}$, and $\mathrm{SiO}_{2}$

4 Total concentration of $\mathrm{Ag}, \mathrm{Al}, \mathrm{Ba}, \mathrm{Cu}, \quad 8(E(8,3), \mathrm{X}(1))$. $\mathrm{Fe}, \mathrm{Hg}, \mathrm{Li}$, and $\mathrm{Mn}$

5 Total concentration of $\mathrm{Pb}, \mathrm{Sr}, \mathrm{Zn}$, $8(E(8,3), x(1)$ $\mathrm{AS}(\mathrm{OH})_{4}, \mathrm{PO}_{4}, \mathrm{~F}, \mathrm{H}_{3} \mathrm{BO} 3$, and $\mathrm{NH}_{3}$

6 Total concentration of $\mathrm{H}_{2} \mathrm{~S}, \mathrm{CO}_{3}$ and $\mathrm{NO}_{3}$ $3(E(8,3), X(1)$ 
$6+H$ Optional data including DENS (density if $(N=0$ to 3$) \neq 1.0)$, EHMC (the EMF in volts of the Eh cell including the Calomel reference electrode), EMFZSCE (the EMF in volts of the En cell calibrated using Zobell's solution). The values of FLAGl-5 may be changed from "0" to "I". To suppress the printout of "TABLES" and "RATIOS" put INFORM $=1$, and RATIO $=1$. These cards may also be used to temporarily supercede the $\log (K T)$ values of any species in table 1, for example, "LOGKT $(36)=\quad "$

$6+N+1 \quad$ Blank card separating every sample, and at end of last sample.

\section{Data directed}

format. For

example,

FLAGl $=1,-\cdots---$

INFORM $=1$;

Separate the data with commas and end with semicolon.

Blank 
The total concentrations used in SOLMNEQ should be for the species mentioned in cards 3 through 6 and in the specified order. Zeros, in the appropriate format, must be used for the concentrations of those species appearing in cards 3 through 6 but not reported in the chemicaf analyses of the sample.

FLAGI through FLAG5 are dummy identifiers which have been initialized in SOLMNEQ as $=0$. The value of any one of these FLAGs, however, may be changed to (I) if an alternate specified method of computation is desired. SOLMNEQ equates the activity coefficient of the neutral species in solution to the computed activity coefficient of dissolved carbon dioxide. The activity coefficient of the neutral species will be $=1.0$ when FLAGI $=1$.

If the Eh of the sample is known and it is desired that the concentration of any or all of the species $\mathrm{Cu}^{++}, \mathrm{Fe}^{+3}, \mathrm{Hg}^{++}$, and $\mathrm{Mn}^{+3}$ be computed from equations similar to equation 14 , then put FLAG2 through FLAG5 = 1. The concentrations of these species, otherwise, will be computed from equations $4,5,6$, and 7 (table 1), respectively

It should be noted that the input value to be assigned to the concentration units variable (FLAG) must be punched left-justified in the appropriate field. 


\section{OUTPUT (RESULTS)}

A printout from SOLMNEQ for a test sample of sea water composition (after Goldberg, 1963) is shown on Appendix 3. Table 2

gives the list of identifiers used in SOLMNEQ and their significance. A typical printout includes a listing of SOLMNEQ, a printout of the data file (TABLES) as well as the results of the computations. SOLMNEQ (see Appendix I for listing) is written for the IBM 360 computer and conforms to $\mathrm{PL} / \mathrm{I}$ language as given in the IBM reference manual (IBM GC28-6594, 1972). 


\begin{tabular}{|c|c|c|c|}
\hline Ti.l luterifier & & $3: x t \quad x y m b)$ & Significence \\
\hline A & & A. & Molal Debye-Hïckel coefficlent defined in equation (5) \\
\hline AGTOT,.... XIOT & & $-\infty$ & $\begin{array}{l}\text { Total analyzed concentration of } A B ; X \text { is for the spentes } \\
\text { shown. on the input section }\end{array}$ \\
\hline AH2O & & $\mathrm{a}_{\mathrm{H}_{2} \mathrm{O}}$ & Activity of water \\
\hline ALFA $(0: 161)$ & & $a_{i}$ & $\begin{array}{l}\text { Array for the activity of the aqueous species shown on } \\
\text { App. } 2 B \text {. }\end{array}$ \\
\hline ANALCO3 & & $-\cdots$ & Total concentration of all the carbonate species in solution. \\
\hline $\operatorname{ANALM}(0: 161)$ & & $m_{i}$ & $\begin{array}{l}\text { Array for the analyzed molelity of the equeous species shown } \\
\text { on Table } 1 \text {. }\end{array}$ \\
\hline $\operatorname{AP}(138: 295)$ & & $A P=Q$ & $\begin{array}{l}\text { Array for the ectivity product of minerals in solution defined } \\
\text { in equation (18). }\end{array}$ \\
\hline 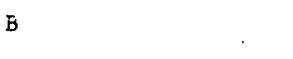 & & B & Molal Debye-Hïckel coefficient defired in equation ( 5$)$. \\
\hline $\operatorname{BDAT}(10)$ & & $-\infty$ & Array for $B^{*}$ (see below) as a function of temperature (App. 2D) \\
\hline BDOT & & $\mathrm{B}^{*}$ & Deviation function defined in equation (4). \\
\hline C & $\cdot$ & 2.303 & Conversion factor from $(\ln )$ to $(\log 10)$ \\
\hline zOZTIT & & - - - & Analyzed molality of $\left(\mathrm{CO}_{3}^{--}+\mathrm{HCO}_{3}^{-}\right)$ \\
\hline zUchot. & & $--\cdots$ & Computed molallties of $\mathrm{CC}_{3}^{--}, \mathrm{HCO}_{3}^{-}$and $\mathrm{I?}_{2} \mathrm{CO}_{3}$ \\
\hline SO JCALC & & $\mathrm{m}_{\mathrm{CO}_{3}}^{-}$ & Computed molelity of $\mathrm{CO}_{3}^{--}$ \\
\hline CURITS $(0: 161)$ & & $\mathrm{ppm}$ or $\mathrm{mg} / 1,-$ etc. & Reported concentration units \\
\hline DENS & & $\rho$ & Density of water \\
\hline $\operatorname{DHA}(0: 16 i)$ & & $a^{\circ}$ & Array for the distance of the nearest approach of lons in solutions \\
\hline EIM & & Ehm & Measured Eh oxidation potential \\
\hline HMC & . & EHMC & Emf of the Eh Cell including the Calomel reference electrode \\
\hline MPFSCE & & ExPZSCE & Emf of the En Cell celibrated using Zobell's solution \\
\hline IPMAN & & $-\cdots-$ & Total mill1equivalent of anions/liter \\
\hline FPMCAT & & --- & Total milliequivalent of cations/11ter \\
\hline$r$ & & $F$ & The Faraday constant \\
\hline FLAG, FLAG1-5 & & $\cdots-$ & See input \\
\hline$G=\operatorname{GAM} \cdot \cos 2(0: 3,10)$ & & $\Upsilon_{\mathrm{CO}_{2}}$ & $\begin{array}{l}\text { Array for the activity coefficient of dissolved } \mathrm{CO}_{2} \text { as a function } \\
\text { of an equivalent } \mathrm{NaCl} \text { solution and temp. (App. 2C) }\end{array}$ \\
\hline GAMMA $(0: 16 !)$ & & $\gamma_{i}$ & Array for the activity coefficlents of the dissolved specles \\
\hline$G A T(0: 151)$ & & GFW & $\begin{array}{l}\text { Array for the gram formula welght of the aqueous species } \\
\text { (App. 2B) }\end{array}$ \\
\hline IHFORN & & $-\cdots$ & See input \\
\hline
\end{tabular}


Table 2.-- List of 1dentifiers used in SOLMNEi and their significance (continued)

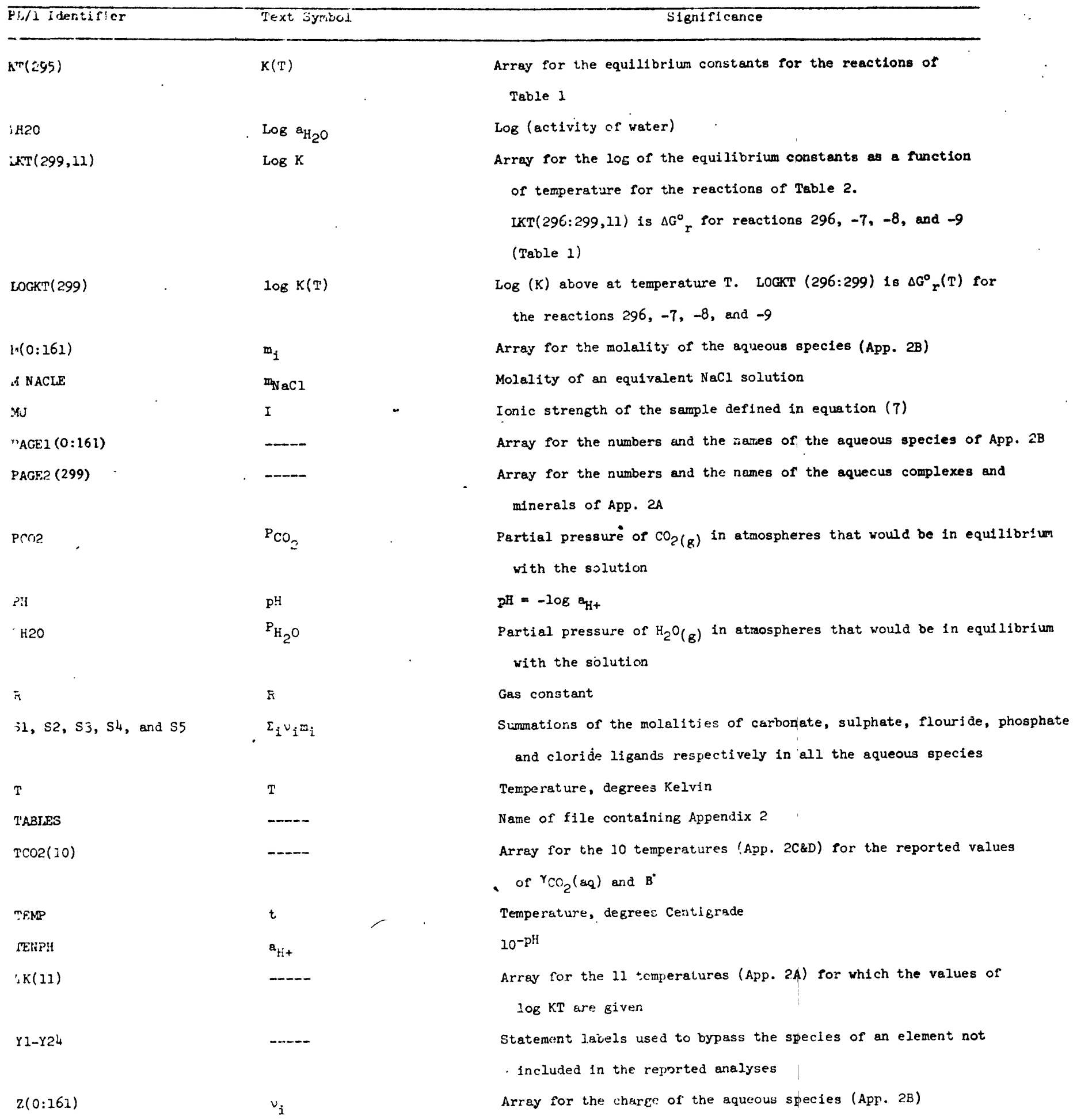


The data file "TABLES" (App. 2) consists of the following:

1. A two-dimensional array (App. 2A) of $\log \mathrm{KT}(299,11)$ values at the 11 specified temperatures. The reaction numbers as well as the aqueous complexes (Nos. I through 136) and minerals (137 through 295) are also indicated. Dummy values of 999.99 appear where no thermodynamic data are available. The values reported for the reaction numbers 296 through 299 are the standard free energies of reaction $\left(\Delta G_{r}^{\circ}(T)\right)$ for the indicated oxidation-reduction reactions at the specified temperatures. Table 1 gives the names of the species, the reactions, and the source of $\log K$ values.

2. A list of the aqueous species involved in the computations (App. 2B). This consists of the program number, name, charge ( $\mathrm{Z})$, distance of the nearest approach (DHA), and gram formula weight (GFW) of the species.

3. A two-dimensional array of the activity coefficient of the dissolved $\mathrm{CO}_{2}\left(\gamma_{\mathrm{CO}_{2}}\right)$ as a function of temperature and an equivalent $\mathrm{NaCl}$ solution (Helgeson, 1969) (App. 2C).

4. A one-dimensional array of $\mathrm{B}^{\cdot}$ (BDOT) as a function of temperature (Helgeson, 1969) (App. 2D). 
Thie results of the computatations carried out by this program and appearing in the printout (App. 3) consist of the following:

1. A list consisting of information read into SOLMNEQ (sample description, concentration units, $\mathrm{pH}$, Eh (if measured), and temperature), the computed value of Eh (computed from field measurements; a dummy value of 9.0000 is printed when no Eh data are available), total milliequivalent of cations (MEQ/L CAT) and anions (MEQ/L AN) computed from the analytical data (ANAL...) and from the calculated molalities (CALC...), the ionic strength of solution (I), the molality and $\mathrm{ppm}$ of the dissolved $\mathrm{CO}_{2}$, and the partial pressures, in atmospheres, of $\mathrm{CO}_{2(\mathrm{~g})}\left(\mathrm{P}_{\mathrm{CO}_{2}}\right)$ and $\mathrm{H}_{2} \mathrm{O}(\mathrm{g})\left(\mathrm{P}_{\mathrm{H}_{2} \mathrm{O}}\right)$ in equilibrium with the solution.

2. A table showing the distribution of species in solution. This consists of the index number and name of the species ( 0 to 161), reported and computed ppm (ANAL PPM, CALC PPM), reported and computed $\mathrm{mg} / \mathrm{l}$ (ANAL MG/L, CALC MG/LP, reported and computed molality (ANAL MOLAL, CALC MOLAL), activity (ALFA), activity coefficient (GAMMA), and $-\log$ activity (PION).

This table can be used to calculate the degree of complexing in the solution under study.

3. Ratios of a number of cations and anions of importance in geochemical processes. These consist of the mole ratios 
of cations and anions which may aid in deciphering the origin of the water samples (White, 1965; Kharaka, 1971) and logs of the activity ratios of a number of cations used to study the stability fields of minerals. The subsurface temperature of a geothermal reservoir is computed by six different geochemical methods (see App. 1 for the details of computations). A number of criteria for selecting the most probable temperature are also printed. (Fournier and Truesde11, 1973; and references cited therein).

The computation and printout of these ratios and temperatures may be suppressed by inputting "RATIO $=1$ " in the optional data.

4. A table showing the states of reactions for 158 minerals considered. The "DELG" column gives the ( $\left.\Delta G_{\text {diff }}\right)$, in kilocalories, of equation 19. A positive (DELG) value indicates that the solution is supersaturated with respect to the given mineral; a negative (DELG) value indicates undersaturation with respect to it. This table also shows the mineral name and its computer numbers, $A P=Q$ (equation 19), the value of $\mathrm{K}$ at temperature $\mathrm{T}, \log (\mathrm{AP}), \log (\mathrm{KT})$, $\mathrm{AP} / \mathrm{KT}$ and $\log \mathrm{AP} / \mathrm{KT}$. The activity product (AP) and IOG(AP) as well as (AP/KT), DELG and IOG AP/Kr of a mineral which contains a species not reported in the chemical analyses of the water sample will be blank. However, an arbitrary value may be assigned to the concentration of any desired species. A dummy value of 59.9990 is printed for the LOG KT 
$(9.9770 \mathrm{E}+59$ for $\mathrm{KT})$ where these are unknown. The $\log (\mathrm{KT})$

of a number of minerals (for example, kenyaite, magadite)

is known only at $25^{\circ} \mathrm{C}$; it is assumed constant at other temperatures. The "DELG" values obtained for these minerals will not be too significant if the temperature of the sample varies by more than about $10^{\circ} \mathrm{C}$ from $25^{\circ} \mathrm{C}$.

It is important to repeat here that (DELG). indicates that the reaction can proceed but does not mean that it will proceed in the specified direction. It is possible for a given solution to be supersaturated (unstable but persistent condition) with respect to a mineral by a number of kilocalories without precipitation. It is also important to note here that large uncertainties are involved in the computed $\log (\mathrm{KT})$ values for most aqueous complexes at temperatures higher than $\sim 200^{\circ} \mathrm{C}$. 


\section{REFERENCES CTTED}

Akerlof, G. C., and Oshry, H. I., 1950, The dielectric constant of water at high temperatures and in equilibrium with its vapor: Am. Chem. Soc. Jour., v. 72, p. 2844-2847.

Barnes, H. L., Romberger, S. B., and Stemprok, M., 1967, Ore solution chemistry II. Solubility of HgS in sulfide solutions: Econ. Geology, v. 62, p. 957-982.

Barnes, Ivan, and Back, William, 1964, Geochemistry of iron-rich ground water of southern Maryland: Jour. Geology, v. 72, p. $435-447$.

Barnes, Ivan, and Clarke, F. E., 1969, Chemical properties of ground water and their encrustation effects on wells: U.S. Geol. Survey Prof. Paper 498-D, 58 p.

Berner, R. A., 1967, Comparative dissolution characteristics of carbonate minera1s in the presence and absence of aqueous magnesium ion: Am. Jour. Sci., v. 265, p. 45-70. Bricker, 0. P., 1969, Stability constants and Gibbs free energies of magadiite and kenyaite: Am. Mineralogist, v. 54, p. 1026-1033. Chave, K. E., 1960, Evidence on history of sea water from chemistry of deep subsurface waters of ancient basins: Am. Assoc. Petroleum Geologists Bu11., v. 44, p. 357-370.

Childs, C. W., 1970, A potentiometric study of equilibria in aqueous divalent metal orthophosphate solutions: Inorg. Chem., v. 9, p. $2465-2469$.

Chughtai, A., Marsha11, A., and Nanco1las, G. H., 1968, Complexes in calcium phosphate solutions: Jour Phys: Chem., v. 72, p. 208-211. 
Cobble, J. W., 1964, The thermodynamic properties of high temperature aqueous solutions: VI. Applications of entropy correspondence to thermodynamics and kinetics: Am. Chem. Soc. Jour., v. 86, p. 5394-5400.

Ellis, A. J., and Giggenbach, W., 1971, Hydrogen sulphide ionization and sulphur hydrolysis in high temperature solution: Geochim. Cosmochim. Acta, v. 35, p. 246-260.

Ellis, A. J., and Golding, R. M., 1963, The solubility of carbon dioxide above $100^{\circ} \mathrm{C}$ in water and in sodium chloride solutions: Am. Jour. Sci., v. 26l, p. 47-60.

Fisher, J. R., and Barnes, H. L., 1972, The ion product of water to $350^{\circ} \mathrm{C}$ : Jour. Phys. Chemistry, v. 76, p. 90-99.

Fournier, R. 0., 1973, Silicon in thermal water: laboratory and field investigation: Internat. Symposium on Hydrogeochemistry and Biogeochemistry, Tokyo 1970, Assoc, of Geochim. and Cosmochim. (in press).

Fournier, R. O., and Rowe, J. J., 1962, The solubility of cristobalite along the three phase curve, gas plus liquid plus cristobalite: Am. Mineralogist, v. 47, p. 897-902.

Fournier, R. O., and Truesdell, A. H., 1973, An empirical Na-K-Ca geothermometer for natural water: Geochim. Cosmochim. Acta (in press). $\Delta$ Garrels, R. M., and Christ, C. L., 1965, Solutions, minerals and equilibria: New York, Harper \& Row, 450 p. 
Harned, H. S., and Owen, B. B., 1958, The physical chemistry of electrolyte solutions: New York, Reinhold Publishing Co., 803 p. Helgeson, H. C., 1967, Thermodynamics of complex dissociation in aqueous solution at elevated temperatures: Jour. Phys. Chemistry, v. 71, p. $3121-3136$.

1969, Thermodynamics of hydrothermal systems at elevated temperatures and pressures: Am. Jour Sci., v. 267, p. 729-804. 1971a, KELYCOB - Computer program library No. 0802D/E:

Theoretical Geochemistry: Univ. of Calif., Berkeley. 1971b, DQUANT - Computer program Library No. 0405AR: Theoretical Geochemistry: Univ. of Calif., Berkeley. 1971c, Kinetics of mass transfer among silicates and aqueous solutions: Geochim. Cosmochim. Acta, v. 35, p. 421-469. Andrew

Helgeson, H. C., Brown, T. H., Nigrini, /, and Jones, T. A., 1970 , Calculation of mass transfer in geochemical processes involving aqueous solutions: Geochim. Cosmochim. Acta, v. 34 , p. 569-592. Hem, J. D., and Roberson, C. E., 1967, Form and stability of aluminumi hydroxide complexes in dilute solution: U.S. Geol. Survey WaterSupply Paper 1827A, 55 p.

Hemley, J. J., Hostetler, P. B., Gude, A. J., and Mountjoy, W. T., 1969, Some stability relations of alunite: Econ. Geology, v. 64, p. $599-612$.

IBM System/360 Operating System, 1972, PL/I[F] language reference manual: IBM GC28-6594, 445 p. 
Keenan, J. H., and Keys, Frederick, 1963, Thermodynamic properties of steam: New York, John Wiley and Sons, 89 p.

Kelley, K. K., 1960, Contributions to the data on theoretical metaliurgy. XIII. High temperature heat content, heat capacity and entropy data for the elements and inorganic compounds: U.S. Bur. Mines Bull. no. 584, 232 p.

Kharaka, Y. K., 1971, Simultaneous flow of water and solutes through geological membrane: Experimental and field investigations: Ph.D. thesis, University of Calif., Berkeley, 274 p. Kielland, Jacob, 1937, Individual activity coefficients of ions in aqueous solutions: Am. Chem. Soc. Jour., v. 59, p. 1675-1678. Lafon, G. M., 1969, Some quantitative aspects of the chemical evolution of the oceans: Ph.D thesis, Northwestern University., Evanston, I11.

Langmuir, Donald, 1965, Stability of carbonates in the system CaO-MgO- $\mathrm{CO}_{2}-\mathrm{H}_{2} \mathrm{O}$ : Jour. Geology, v. 73, p. 755-780. 1969, The Gibbs free energies of substances in the system $\mathrm{Fe}-\mathrm{O}_{2}-\mathrm{H}_{2} \mathrm{O}-\mathrm{CO}_{2}$ at $25^{\circ} \mathrm{C}$ : U.S. Geol. Survey Prof. Paper 650-B, B180-B184. 1971, Particle size effect on the reaction Goethite = Hematite + water: Am. Jour. Sci., v. 271, p. 147-156. 
Lieser, K. H., 1965, Radiochemische Messung der Lobhchkeit von Erdalkafisulfaten in Wasser und in Matrium sulfatlösinger: Z. Anorg. Allgem. Chem., v. 335, p. 225-231.

Lewis, G. N., and Randall, Merle, 1961, Thermodynamics: New York, McGraw-Hill, $723 \mathrm{p}$.

Mesmer, R. E., Baes, C. F., and Sweeton, F. H., 1972, Acidity

measurements at elevated temperatures: VI. Boric acid

equilibrium: Inorg. Chemistry, v. 11, p. 536-543.

Morey, G. W., Foumier, R. O., and Rowe, J. J., 1962, The solubility

of quartz in water in the temperature interval from $25^{\circ} \mathrm{C}$ to $300^{\circ} \mathrm{C}$ Geochim. Cosmochim. Acta, v. 26, p. 1029-1043.

Naumov, A. B., Ryzhenko, B. N., and Khodakovskii, I. L., 1971, Handbook of thermodynamic data (Spravochnik Termodinamichesnikh Velichnin) Moscow, Atomizdat, $239 \mathrm{p}$.

Nriagu, J. 0., 1972, Stability of vivianite and ion-pair formation in in the system $\mathrm{Fe}_{3}\left(\mathrm{PO}_{4}\right)-\mathrm{H}_{3} \mathrm{PO}_{4}-\mathrm{H}_{2} \mathrm{O}$ : Geochim. Cosmochim. Acta, v. 36 , p. $45 S-470$.

Páčes, Tomáš, 1968, Chemical equilibria and zoning of subsurface water from Jacymov ore deposit, Czechoslovakia: Geochim. Cosmochim. Acta, v. 33, p. 591-609.

1971, Chemical characteristics and equilibration in natural water-felsic rock- $\mathrm{CO}_{2}$ system: Geochim. Cosmochim. Acta, v. 36 , p. $217-240$. 
Rainwater, F. H., and Thatcher, L. L., 1960, Methods for collection and analysis of water samples: U.S. Geol. Survey Water-Supply Paper 1454, 301 p.

Robie, R. A., and Waldbaum, D. R., 1968, Thermodynamic properties of minerals and related substances at $298.15^{\circ} \mathrm{K}\left(25.0^{\circ} \mathrm{C}\right)$ and one atmosphere ( 1.013 bars) pressure and at higher temperatures: U.S. Geol. Survey Bull. 1259, 256 p.

Sillén, L. G., and Martell, A. E., 1964, Stability constants of metalion complexes: Chem. Soc. [London], 754 p.

Truesdell, A. H., 1973, ENTHALP, a computer program for the calculation of down-hole chemistry in geothermal areas: U.S. Geol. Survey Comp. Contrib. (in press).

Wagman, D. D., and others, 1968 and 1969, Selected values of chemical thermodynamic properties: NBS Technical Note No. 270-3; No. $270-4$.

White, D. E., 1965, Saline waters of sedimentary rocks, in Young, Addison, and Galley, J. E., eds., Fluids in subsurface environments: Am. Assoc. Petroleum Geologists Mem. 4, p. 342-366. Wright, J. M., Lindsay, W. T., and Druga, T. R., 1961, The behavior of electrolytic solutions at elevated temperatures as derived from conductivity measurements: U.S. Atomic Energy Comm. WAPD-IM-204. Zen, E-an, 1972, Gibbs free energy, enthalpy and entropy of ten rock-forming minerals: Calculations, discrepancies, implications: Am. Mineralogist, v. 57, p. 524-553. 
$1+$

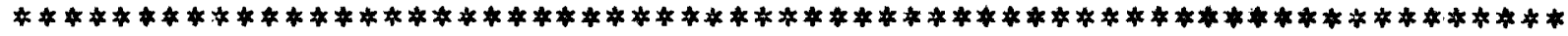

THIS PROGRAM IS WPITTEN FOR THE IBM 360 COMPUTER \& CONFORMS TO PL/I LANGUAGE AS GIVEN IN THE IBMGC28-6594REFERENCE MANUAL. THIS PRUGRAM WAS WRITTEN BY YOUSIF K. KHARAKA,U.CALIFORNIA, BERKELFY, WHILE WOPKIVG AT U.S.GEULOGICAL SUPVEY. SULMNEO WAS BASED I'I PART IN WAICHFM \& WATEO. THIS VFKSIO'N WAS COMPLFTFD AUGUST/1972.

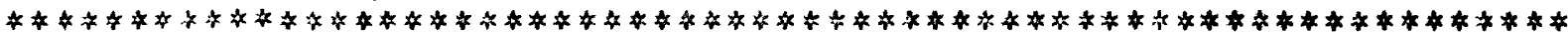

SOLMVFO: PROCFOUHF OPTIONS (MAIN):

1 *

PIJRPUSE :

TABLE-LOIK-UP ANII LAGRANGF INTFRPOLATION SUBROUTINE

DESCRIPTION DF PARAMETEPS

$x$ - the value of the indepfadent VARIABLf IFOR wHICH THE VALUE OF THE DEPENDEIVT VARIABLE AND/TR ITS DERIVATIVES ARE DESIREDI.

$X I$ - TABLE OF ' $X$ ' VALUFS IN ASCENUING ORDFR.

YT - TABLE OF CORRESPONDING 'Y' VALUES.

$N$ - NUMBER OF ENTRIES IN THE TABLE. IDIMFNSIUN OF XT AND YT MUST BE AT LEAST N)

$Y$ - COMPUTEO VALUE OF DEPFNOENT VARIABLE CORRESPONDING TO $Y$.

\section{TLUV: PROCEDURE $(X T, Y T, X, Y)$;}

DECLARE (LU,UP, DIF,MID,K, iV), FIXED BIINARY (31),

$(X, Y(>99), X T(11), Y T(293,11))$ FLOAT DEC $(16)$,

(W(10),C(4)) FLOAT DECIMAL (16) STATIC;

$V=11$;

$L(1)=1 ;$

$U P=V$;

$M I D=1 ;$

IF $X>X T(N)$ THEN DU;

PUT EDIT $(\cdot x-() \cup T$ IN TLU, $X=1, x, \cdot x T(N)=\cdot, x T(N))$

$(S K I P(3), X(3), A, F(13,6), X(2), A, E(13,6))$;

GU TO START;

$M I D=N-1$;

GUTT BSTEP;

END;

IF $X<X T(1)$ THEN DO;

PIIT EOIT $(\cdot x$-JUT IN TLU, $x=1, x, \cdot x T(1)=1, x T(1))$

GU TU START;

$(S K[P(3), X(3), A, F(13,6), X(2), A, E(13,6))$ :

$M(1)=3$;

GUTA BSTEP; 


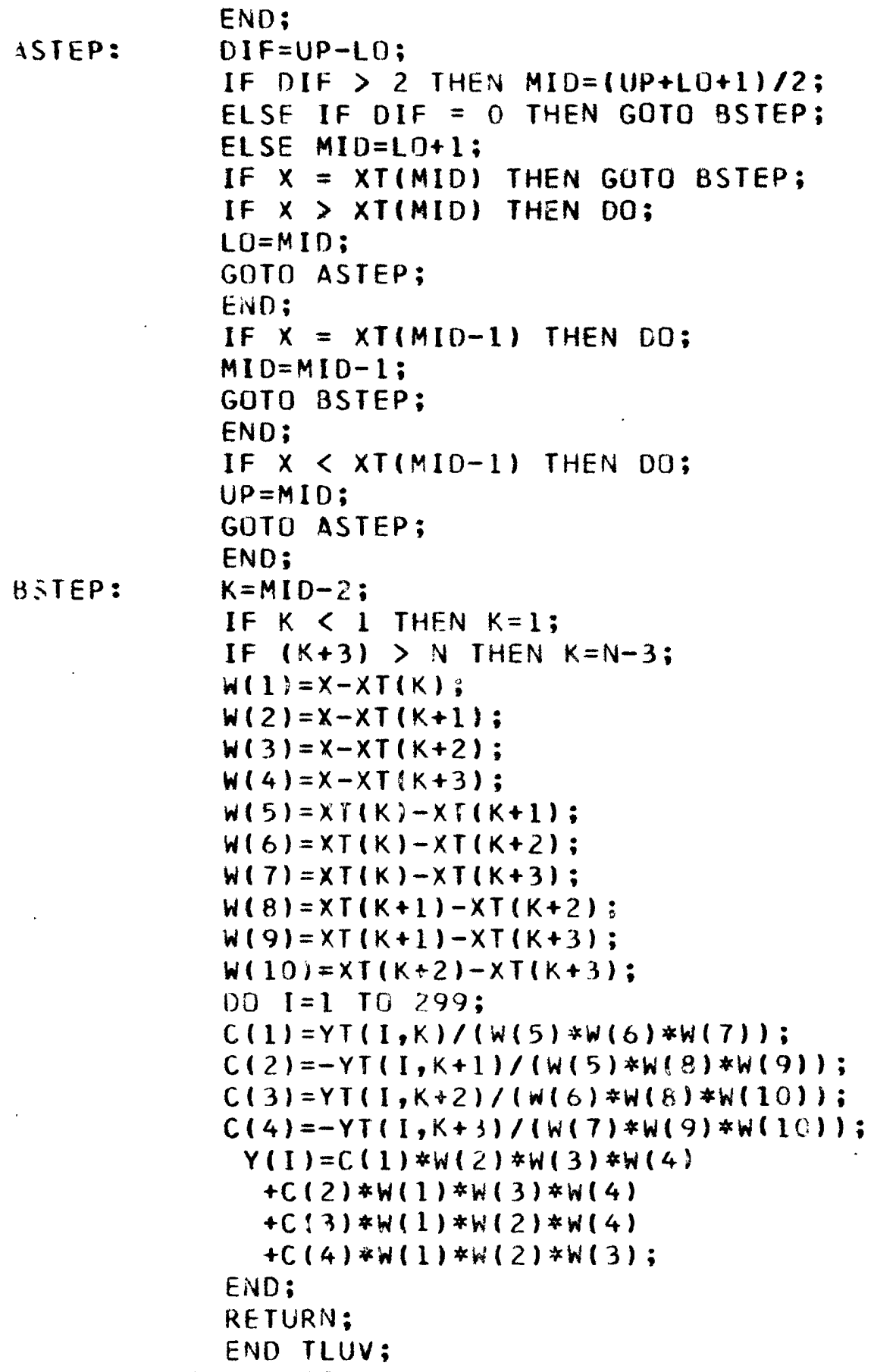


$(F(3), X(1), A(8), X(1), F(2), X(1), F(3,1), X(1), F(8,4)$, SKIP ); GET FILE(TABLES) EUIT( I,PAGEZ(I),LKT(I, , DO $J=1$ TU 299$)$

$(S K I P, F(3), X(1), A(8), 7(X(1), F(7,2)), S K I P, X(13), 4(F(7,2), X(1))$; GET FILE(TABLES) EOIT(I,GAMACU2(I, 1 DO $J=0$ TO 3$)$

(SKIP,F(1), $10(X(1), F(4,2)) 1$; DET FILE(TAELES) EOIT(I)AT(I) DU I=1 TO 131$)$

(SKIP, 1O(F $(5,3), \times(1)))$;

(GET FILE(TARLFS) EI)IT((TKII) OO) I=I TO 111$)$

$(S K I P, F(3,1), 3(\times(1), F(4,1)), 7(X(1), F(5,1)))$;

SFF FILF(TABLES) TUIT(ICO) (I) DH) $I=1$ TU 101$)$

(SKIP,F $(3,1), ?(X(1), F(4,1), 7(X(1), F(5,1))$;

ISPEN FILE(SYSPPI ITIPP.IIVT LINESILE(13?);

ON ENDFILE (SYSIN) GU TO EOF;

UN CONVERSIUN BEGI:;

PUT FILE (SYSPRINT) ERIT ('INPUT CONVERSIUN FRROR', UNCHA?,

UNSIURLE) (PAGE, $A, X(2), A, X(2), A)$

( (CARO(I) DO I = TU NU) (SK $(P, A)$;

GO TI START; ENII;

$C=2.302595 ; F=23.0603 ; R=1.98719 E-3 ;$

START: CUNITS, ALFA, M=OEO;

EHM, EHMC, EMFZSCE = 9EO;

$J=1 ; D E N S=L E C ; \quad \angle D G K T=0 E 0 ; \quad K T=O F O$;

RATIU, INFORM, FLAG1, FLAG2, FLAG3, FLAG4, FLAG5=0;

C.REED: GET FILE(SYSIN) EI)IT (CARD(N)) (AI8O));

IF CARD $(N) \rightarrow=0$ - THEN DO;

$11=N+1 ; G U$ TU CREEU; END;

$N=11-1 ; \quad \operatorname{LONG}=\cdots$;

i) I I $=2$ TO 6; LONT=LUNGIICAPU(I); ENU;

in $1=0$ TO $6,11,12,13,14,15,17,20,21,22,24,25,26,27,29,29,30$,

$31,32,97,135$;

CUNITSII) =999997EO; ENU);

CFT STEIVGILUNG) EOIT (TEMP, PH, FHM,FI.AS, ICUNITSII)

[D] $I=r$ T11 $6,11,12,13,14,15,17,20,21,72,24,25,26,27,28,29,30$.

$31,32,77,135))(t(6,1), x(1), E(6,2), x(1), E(9,3), \times(1), 1(5), x(5) 1$,

$8([(3,3), x(1)), \times(8), 8(F(8,3), x(1)), x(8), 8(-18,3), x(1)), x(8)$,

$3(E(B, 3), \times(1)))$;

IF CUNITS(II>6.JES THEN DU;

PUT ENITI'INSUFFICIENT NUMBE? IF INPUT UATA ITFMS IN THE",

- FLILLONING SET:") (PAGE,? A)

(ICAROII) DO I =1 TO N) ) (SKIP,A);

SO TO START; ENI:;

I*CALLING THF LMGKT VALUES WHICH ARF INTH RPOLATFis RY LAGRANTE SUBRGUT-

LINE F?UM A LUOKT VS TEMPEPATURE TABLE

CALL ILIIVITK,LKT, IFMP,LIJGKT):

$\operatorname{LONC}=\cdots$;

DU I $=7$ TU IN; LUNG=LUNGIICARDII): EIVII:

IF N>G THEN TET STRIVGILUNGIDATA;

1) $I=1$ Tก 136 ; 
IF LOGKT(I) $<-7.0 E I$ THEN LOGKT(I) $=-7.0 E 1$;

IF LOGKT(I)>2.OE2 THEN LOGKT(I)=2.0EI;

$K T(I)=1 E I * *(\operatorname{LOGKT}(I)) ; \quad$ END;

PRINT of tables. log(KT), List of aquequs species,gamma coz \& bDot. IF PRINT OUT OF TABLFS NOT REQUIRED PUT INFORM=1

IF INFORM $=0$ THEN DU;

PUT SKIP EDITI** TABLE OF LOG(KT) FOR THE AQUEOUS COMPLEXES $\varepsilon^{*}$,

- MINERALS * $)(x(40), 2$ A):

PUT SKIP (2);

PUT SKIP EDIT''I','PAGE2', 'OC', '25C', '50C', 75C', 100C', 125C', '150C', . $\left.200 C^{\prime}, 250 C^{\prime}, 300 C^{\prime}, 350 C \cdot\right)(x(1), A, \times(4), A, \times(6), 4(A, X(8))$,

PUT SKIP (2); $6(A, X(7)), A)$;

DO I $=1$ TO 299;

PUT SKIP EDIT(I,PAGE2(I),LKTII, $\# 1)(F(3), X(1), A, X(2), F(7,2)$, $10(\times(4), F(7,2)))$;

END;

PUT PAGE EDIT $1 *$ LIST OF AQUEUUS SPECIES *',

* * gamma coz as a function uf TEMP. E EQ. NACl **1)(x(3),a, $X(30), A)$;

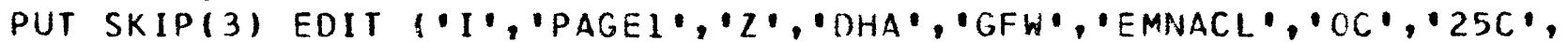
'50C', $\left.100 C^{\prime}, 150 C^{\prime}, 200 C^{\prime}, 250 C^{\prime}, 270 C^{\prime}, \cdot 300 C^{\prime}, 350 C^{\prime}\right)$ $(X(1), A, X(3), A, X(6), A, X(2), A, X(5), A, X(15), A, X(3)$,

PUT SKIP (2): $A, X(4), 2(A, X(3)), 7(A, X(2)), A)$;

DO I=0 TU 161 ;

PUT SKIP ENIT (I,PAGEIII),Z(I), DHAII),GFW(1))

$(F(3), X(2), A, F(4), F(5,1), F(1), 5))$;

IF I $<4$ THEN PUT EDIT(I,GAMACO2 $(I, *)(C O L(47), F(2), X(3)$,

$10 \mathrm{~F}(6,2))$;

END:

PUT SKIP (3) EDIT $(\cdot B D O T=')(\operatorname{COL}(40), A)$;

DO $I=1$ TO 10 ;

PUT EDIT(BDAT(I)) $(F(7,3))$;

END; $\quad$ END;

* Calculatiun of eH from field data * 1

IF EMFZSCE $=9 E 0$ THEN $C 1=.2145 E O-7.6 E-4 *(T E M P-25 E 0)$;

ELSE $C 1=4.28 E-1-2.2 E-3 *(T E M P-25 E 0)-E M F 2 S C E$;

IF EHMC $\angle 9 E O$

THEN EHM = EHMC +Cl ;

* calculation of analyzed molality *

C $3=O E O$; DO I $=0$ TO 161 ;

IF FLAG $=$ PPPM - THEN C $3=C 3+1 E-6 * C$ UNITS(I)*DFNS;

ELSE IF FLAC $=1 M O / L$ - THEN $C 3=C 3+1 E-6 * C$ UNITSII);

ELSE IF FLAG $=M M O L / L$, THEN $C 3=C 3+1 E-3 * C U N I T S(I) * G F W(I)$ :

FLSE IF FLAG $=M M E O / L$ \& $Z(1) \rightarrow=0$ THEN

C $3=C 3+1 E-6 *$ CUNITS(I)*GFW(I)/ABS(Z(I)); END);

IF $F L A G=P P P M$ - THEN $M=1 E-3 * C(I N I T S * D E N S /(G F W *(D E N S-C 3))$; 
ELSE IF FLAG = MGG/L THEN $M=1 E-3 * C U N I T S /(G F W *(D E N S-C 3) 1 ;$

ELSE IF FLAG $=9 M O L / L$ ' THEN $M=C U N I T S /(D E N S-C 3)$ :

ELSE IF FLAG $=$ 'MEQ/L' THEN DO $I=0$ TO 161 ; IF $Z(I) \neg=0$ THEN $M(I)=1 E-3 * C U N I T S(I) /(A B S(Z(I)) *(D E N S-C 3))$; END; $\triangle N A L M=M$; FPMCAT, EPMAN =OEO;

I CALCULATION of CATION-ANIUN BALANCE *

DO $I=0$ TII 161 ;

It ZII)>0 THFN EPMCAT = EPMCAT+Z(I)*M(I):

ELSE FPMAN = EPMA:I-Z(I)*MII); E:ND;

EPMCAT = FPMC, AT * (DEINS-C3);

EPMAN = EPMAN *(DENS-C 3$)$;

1* THMP. EFFECTS ON DEBYE-HUCKEL SOLVENT COVSTANTS *

$S 1=374.11 E O-T E M P$;

$S 2=S 1 * .333333 E O ;$

$53=$ SQRT $((1 E O+.1342489 E O * S 2-3.946263 E-3 * S 1) / 13.1975 E O-$ $.3151548 E 0 * S 2-1.203374 E-3 * S 1+7.48908 E-13 * S 1 * 411$;

$T=T F M P+273 \cdot 16 E O$;

IF $T<373.16 E 0$

THE.V C $1=87.74 E O-T E M P *(T E M P *(1.41 E-6 * T E M P-9.398 E-4) * .4008 E))$;

ELSE $C 1=5321 F 0 / T+233.76 E O-T *(T *(8.292 F-7 * T-1.417 E-3)+.9297 E 0)$;

$C_{1}=S Q R T(C 1 * T)$;

$A=18246 E 2 * S 3 / C 1 * 3 ;$

$B=50.29 * 53 / C 1 ;$

\section{1* ** CALCULATION OF PH2O *** *}

PH2OCL $=-1.87 E 0+3.74 E 0 *(1.152894 E 0-.745794 E 0 *$ LOG $(654.2906 E 0 / 1 T E M P+$

$766.778 E 0)+$ SGRT $((654.2906 E 0 /(T E M P+266.778 E 0)) * 2-1 E 0)))$;

PH2OC 2 =PH2OC 1*2*(3.4969EO-PH2OC1*2)/(.30231574E0+.3377565E-2*TEMP);

LUG $10 P H 20=1.0642332 E 0+4.16385282 E 0 *(T E M P-187 E 0) /(T E M P+237.098157 E 0)-$

$1.0137921 E 0 *(1 E 0+5.83531 E-4 * T E M P) * 3.97307778 E-3 *((1 E-2 * T E M P-1.87 E 0)-$

$1 E-2 * P H 2 O C 2) *(3.4969 E 0-(1 E-2 * T E M P-1.87 E O-1 E-2 * P H 2 O C 2) * 2)$;

PH $20=10 E O *$ LOG 1 OPH $20 ;$

I* INITIALIZF STARTING VALUES FOR ITERATIVE LUUP AND CONSTANT gaMMAS *I

CATOT=M(O); MGTOT=M(1); NATOT=M(2);

$K$ TOT $=M(3) ; C L T O T=M(4) ; S O 4 T O T, S O 4 I T R=M(5)$;

HCO3TOT $=M(6) ; \quad S I T O T=M(11) ; A G T O T=M(12) ;$

$A L T O T=M(13) ; B A T O T=M(14) ; C U T O T=M(15) ;$

FETOT $=M(17) ; H G T O T=M(20) ; L I T O T=M(21) ;$

$M N T O T=M(22) ;$ PBTOT $=M(24) ; \quad S R T O T=M(25) ;$

LVTOT $=M(26) ; A S T O T=M(27) ; P T U T, P I T R=M(28) ;$

FTOT $=M(29) ; B T O T=M(30) ; \quad N H 3 T) T=M(31)$;

H2STOT $=M(32) ; C O 2 T I T, C O 2 T O T=M(6)+M(97) ;$

TENPH $=1 F 1 *(-P H)$;

PUT PAGE EDIT (CARD(1)) (A);

PUT SKIP EUITI'ITER', 'S I-ANALCO3', S2-ANALSU4 ${ }^{\circ}$, 'S3-ANALF',

' S4-AIVALP(1) ', S5-ANALCL')

$(S K(P(?), X(?), A, X(9), A, X(10), A, 3(\times(11), A))$;

ITER $=0 ;$ RBIT $=11 \cdot B ; D D$ WHILE $(R B I T) ;$ ITFR =ITER+1;

/*CALC. UF TUTAL MOLALITY \& AH2O */ 
C $1=0 E 0 ;$ DO $1=0$ TO $8,10,12$ TO 30,32 TO 161 ;

$C 1=C 1+M(1) ; E N D$;

$A H 2 O=1 E O-1.7 E-2 * C 1 ; L H 2 O=L O G 10(A H 20) ;$

the folluwing ruUtine estimates the gamma uf cu2 py linear interpuLATION BETWEen THE KNOWN VALUES DF GAMMA CO2 GIVEN AS a FUNCTIDN DF TEMPERATURE AND EQUIVALENT MNACL (NACLE) *

1* CALCULATION OF THE IONIC STRENGTH (I), EQUIVALFNT MNACLE=I*/

$M U=O E O$;

DO $I=0$ TO 161 ;

$M U=M U+M(1) * 2(I) * 2$;

END;

$M U=.5 E O * M U$;

MUHALF $=$ SQRT $(M U)$;

MNACLE $=$ MU;

IF MNACLE>3. OEO THEN MNACLE=3.OEO;

$G=G A M A C \cap 2$;

$M J=T R U N C(M N A C L E)$;

nO $I=1$ IO 10 ;

IF TEMP> TCOZ2(I) THEN

GO TO SKIP;

IF TEMP $=$ TCO2(I) THEN

DI]; $\quad G$ T I $=G(M J, I) ; \quad G T 2=G(M J+1, I) ; \quad M J=M J+1 ; \quad E N D$;

IF TEMP $=$ YCO2(I) THEN GO TO CUTB;

$G T I=G(M J, I-1)+(T E M P-T C O 2(I-1)) *(G(M J, I)-G(M J, I-1)) /(T C O 2(I)-$ $\operatorname{TCO}(1-1))$;

GO TO OUT:

SKIP: END;

[UT: $M J=M J+1$;

$G T 2=G(M J, I-1)+(T E M P-T C \cap 2(I-1))(G(M J, I)-G(M J, I-1)) /(T C U 2(I)-$ TCU2 $(1-1):$ :

DUTB: $\quad$ GTM=GT 1+(MNACLE-(MJ-1))*(GT2-GT1);

1* CALCULATION DF ACTIVITY COEFFICIENTS. GAMMA FOR NEUTRAL SPECIES= GAMMA CO2, THEY ARE $=1$. IF FLAGI $=1$. GAMMA FOR CHARCHED SPECIES IS BY BDOT METHOD, HFLGESON, 1969.*1

IF TEMP > 3OOEO THEN BDOT = OEO;

ELSE DO $J=1$ TO 9 ;

IF TEMP $=$ TCU2(J) THEN

BDOT = RDAT $(J)$;

ELSE IF TEMP > TCO2(J) THEN GO TO ADD;

FLSE BDOT = BDAT $(J-1)+(\operatorname{TEMP}-T C 02(\mathrm{~J}-1)) *(B D A T(J)-B O A T(J-1)) /$

GO TO CONTINU : $(\operatorname{TCO} 2(\mathrm{~J})-\operatorname{TCO} 2(\mathrm{~J}-1))$;

ADD: END;

CONTINU: DO $I=0$ TU 161 ;

IF $Z(I)=0$ THEN GAMMA $(I)=1 E I * 1-A * M U H A L F * Z(I) * 2 /(1 E O+D H A(I) * B * M U H A L F)$

+BDUT *MU); 
ELSE IF $Z(1)=0$ \& FLAG $=0$ THEN GAMMA $(I)=G T M$;

ELSE IF $Z(I)=0$ \& FLAGI=1 THEN GAMMAII)=LEO; END;

1 * calculation dF a nUmber uf aNIUN ACTIVITIES *

DO $I=4,5,29,135$;

ALFAI I $)=M(I) * G A M M A(I) ; E N U$;

$1 *$ CO2 SPECIES *1

Y1: IF CUNITS $(6)<=0 E 1$ \& CUNITS $(97)<=C E 1$ THFN GO TO Y2;

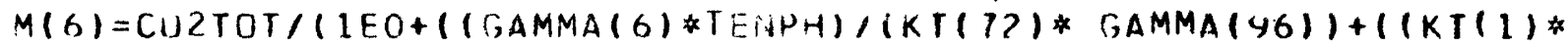
GAMMA(G))/(GAMMA(O) * TENPH)));

$A L F A(6)=M(6) * G A M M A(6)$;

$M(97)=(K T(1) * A L F A(6)) /(G A M M A(97) * T E N P H)$;

ALFA(97)=M(97)*GAMMA(97);

$M(96)=(A L F A(6) * T E N P H) /(K T(72) * 6 A M M A(96))$;

$A L F A(96)=M(96) * G A M M A(96)$;

1 * SULPHUR SPECIES * 1

Y2: IF CUVITS(32) $<=0$ OE THEN GO TO Y3;

$M(100)=H 2 S T O T /(1$ EO+ $($ GAMMA $(100)$ *TENPHT/ $(K T(10) * G A M M A(32))+$

$\left.\left((K T(75) * G A M M A(100)) /\left(G A M M A(101) * T F_{N P H}\right)\right)\right)$;

ALFA 100$)=$ GAMMA $(100) * M(100)$;

$M(32)=(A L F A(100) * T E N P H) /(K T(10) * G A M M A(32))$;

$A L F A(32)=G A M M A(32) * M(32)$;

$M(101)=(K T(75) * A L F A(100)) /(G A M M A(101) * T E N P(1)$;

ALFA $(101)=M(101) * G A M M A(101)$;

Y3: IF CUNITS(5) $\angle=O E 1$ THEN GO TO $Y 4$;

$M(102)=S 04 I T R /\left(1 E D+\left((1 K T(76) *\right.\right.$ SMMA $\left.\left.(102)) /\left(T A M H^{\prime} A(5) * T E N P H\right)\right)\right)$; ALFA $(102)=M(102) * G A M M A(102)$;

$M(5)=(K T(76) * A L F A(102)) /($ GAMMA $(5)$ *TENPH);

$A L F A(5)=M(5) * C A M M A(5)$;

* SILICA SPECIES *I

Y4: IF CUVITS(11) $\angle=O E 1$ THEN GO TO Y5;

$M(90)=S I T O T /(1 E O+($ GAMMA $(90)$ TENPH)/(KI) 3$) * G A N M A(10))+((K T(66)$ *(SAMMA $(90)) /($ GAMMA (89)*TENPH)) ) ;

ALFA $(90)=G A M M A(90) * M(90)$;

iN $(10)=(A L F A(90) * T E * P H) /(K T(3) * G A M M A(10))$;

ALFA(10) $=M(10) * C A M M A(10)$;

$M(89)=(K T(66) * A L F A(\rightarrow 0)) /(G A M M A(89) * T E N P H)$;

ALFA $(89)=M(89) * G A M M A(89)$;

/* ACTIVITY OF OH,H+,HF, AND HNO3 3 *

Y5: $\quad A L F A(8)=(A H Z U * K T(2)) / T E N P H$;

$M(8)=A L F A(8) /$ GAMMA $(8)$;

i $(7)=$ TENPH/GAMMA $(7)$;

$A L F A(7)=$ TENPH;

$M(95)=($ TENPH ALFA(29))/(GAMMA(95)*KT(71));

ALFA $(95)=M(95)$ *GAMMA(95):

$M(103)=(T E N P H * A L F A(135)) /($ GAMMA $(103) * K T(77))$;

IF $[T E Q=1$ THFN $M(135)=M(135)-M(103)$;

$A L F A(103)=M(103) * G A M M A(103)$;

1* BIJRON SPECIFS *I 
IF CUNITS $(30)<=O E 1$ THEN GO TO YG; $M(30)=B$ TOT / (LEO+( (GAMMA (30)*ALFA(8))/(KT(64)*GAMMA(88)) ) ; ALFA(30) $=M(30) *$ GAMMA 30$)$; $M(88)=(A L F A(30) * A L F A(8)) /(K T(64) * G A M M A(88))$; $A L F A(88)=M(88) * G A M M A(88)$;

* PHOSPHATE SPECIES * 1

Y6: IF CUNITS(28) $<=0 E 1$ THEN GO TU Y7;

$M(98)=$ PITR/ ( LEO+ ( (GAMMA $(98) * T E N P H) /(K T(74) * G A M M A(99))+((K T(73) *$ GAMMA(98))/(GAMMA(28)*TENPH))) );

ALFA $(98)=M(98) * G A M M A(98)$;

$M(99)=($ ALFA $(98) *$ TENPH $) /(K T(74) *$ GAMMA $(99))$;

$M(28)=(K T(73)$ *ALFA $(98)) /($ GAMMA $(28)$ *TENPH) ;

ALFA(99) =M(99)*GAMMA(99);

$\operatorname{ALFA}(28)=M(28) * G A M M A(28)$;

$1 *$ NITROGEN SPFCIES *

Y7: IF CUNITS $(31)<=0 E 1$ THEN GO TO Y8;

$M(144)=A L F A(8) /(K T(118) * G A M M A(144))$;

$M(145)=A L F A(28) /(K T(119) * G A M M A(145)) ;$

$M(146)=A L F A(5) /(K T(120) * G A M M A(146))$;

$M(143)=N H 3$ TOT $/(1 E O+$ GAMMA $(143) *(M(144)+M(145)+M(146)))$;

ALFA $(143), C 1=M(143) * G A M M A(143)$;

DO I $=144$ TO 146 ;

$M(I)=M(I) * C 1$;

$\triangle L F A(I)=M(I) * G A M M A(I) ; E N D$;

$1 *$ CA SPECIES *1

Y8: IF CUNITSPO) $\angle=O E I$ THEN GO TO Y9;

$M(54)=A L F A(97) /(K T(30)$ *GAMMA $(54))$;

$M(55)=A L F A(6) /(K T(31) * G A M M A(55))$;

$M(56)=A L F A(8) /(K T(32) *$ GAMMA $(56))$;

$M(57)=A L F A(28) /(K T(33) *$ GAMMA(57));

$M(58)=A L F A(98) /(K T(34) *$ GAMMA $(58))$;

$M(59)=A L F A(99) /(K T(35) * G A M M A(59))$;

$M(60)=A L F A(5) /(K T(36) * G A M M A(60))$;

$M(0)=C A T U T) /(1 E O+G A M M A(0) *(M(54)+M(55)+M(56)+M(57)+M(58)+M(53)+$ $M(60)))$;

$A L F A(0), C l=M(0) \div G A M M A(0)$;

DO I $=54$ TO 60 :

$M(I)=C I * M(I)$;

ALFA I $)=M(I) * G A M M A(I)$;

END;

* MG SPFCIES *

Y9: IF CUNITS(1) $<=0$ OEI THEN GO TO Y1O;

$M(119)=A L F A(97) /(K T(93)$ *GAMMA $(119))$;

$M(120)=A L F A(6) /(K T(94) *$ GAMMA $(120))$;

$M(121)=A L F A(29) /(K T(95)$ *AMMA $(121))$;

$M(122)=A I . F A(8) /(K T(96) * G A M M A(122))$;

$M(123)=A L F A(5) /(K T(97) * G A M M A(123))$;

$M(124)=A L F A(28) /(K r(98) * G A M M A(124))$ : 
$M(125)=A L F A(98) /(K T(99) * G A M M A(125)) ;$

$M(126)=A L F A(99) /(K T(100) * G A M M A(126))$;

$M(1)=M(, T O T /(1 E O+G A M M A(1) *(M(119)+M(120)+M(121)+M(122)+M(123)+$ $M(124)+M(125)+M(126))$;

ALFA(1),C1=M(1) $*$ GAMMA $(1)$;

DO I $=119$ TO 126 ;

$M(I)=M(I) * C I$;

$A L F A(I)=M(I) *(G A M M A(I)$;

END;

* NA SPECIES *I

Y10: IF CUNITS(2) $<=O F I$ THEN GO TO $Y 11$;

$M(136)=A L F A(4) /(K T(110) * G A M M A(136))$;

$M(137)=A L F A(97) /(K T(111)$ *GAMMA $(137))$;

$M(138)=A L F A(6) /(K T(112)$ GAMMA $(138))$;

$M(139)=(M(2) *$ GAMMA $(2) * A L F A(97)) /(K T(113) * G A M M A(139))$;

$M(140)=(M(2) * G A M M A(2) * A L F A(5)) /(K T(114) * G A M M A(140))$;

$M(141)=A L F A(5) /(K T(115) * G A M M A(141))$;

$M(142)=A L F A(98) /(K T(116) * G A M M A(142))$;

$M(2)=N A T D T /(L E O+G A M M A(2) *(M(136)+M(137)+M(138)+M(139)+M(140)+$

$\triangle L F A(2), C 1=M(2) * G A M M A(2)$;

DO $I=136$ TO 142 ;

$M(I)=M(I) * C 1$;

ALFA( I $)=M(I) * G A M M A(I) ; E N D$;

$1 * K$ SPECIES * 1

Y11: IF CUNITS(3) $<=0 E 1$ THEN GO TO Y12;

$M(112)=A L F A(4) /(K T(86) * G A M M A(112))$;

$M(114)=A L F A(102) /(K T(88) * G A M M A(114))$;

$M(115)=A L F A(5) /(K T(89) *$ GAMMA $(115))$;

$M(116)=A L F A(98) /(K T(90) * G A M M A(116))$ :

$M(3)=K T O T /(1 E O+C A M M A(3) *(M(112)+M(114)+M(115)+M(116)))$;

ALFA(3), C1 =M(3)*CAMMA(3);

D(I I $=112,114$ TO 116:

$M(I)=M(I) * C 1$;

ALFA(I) $=M(I) * G A M M A(I) ; E N D$;

1 * AG SPECIES *I

Y12: IF CIINITS(12) $<=0 E I$ THEN GO TO Y13;

$M(4))=A L F A(4) /(K T(20) *(2 A M M A(4))) ;$

$M(43)=A L F A(4) * 2 /(K T(21) * G A M M A(43))$;

$M(44)=A L F A(4) * 3 /(K T(22) * G A M M A(44)) ;$

$M(45)=A L F A(4) * 4 /(K T(23) * \operatorname{GAMMA}(45))$;

$M(46)=A L F A(5) /(K T(24) * G A M M A(46))$;

$M(47)=A L F A(5) * 2 /(K T(25) * G A M M A(47)) ;$

$M(12)=A G T O T /(1 E O+G A M M A(12) *(M(42)+M(43)+M(44)+M(45)+M(46)+$ $M(47))$;

ALFA $(12), C 1=M(12) * G A M M A(12)$;

DO I $=42$ TO 47 ;

$M(I)=M(I) * C 1$; 
ALFAI I $)=M(I) * G A M M A(I) ; E N D$;

I* AL SPECIES */

Y S3: IF CUNITS(13) $<=O E 1$ THEN GO TO Y14;

$M(33)=A L F A(29) /(K T(1) * \operatorname{GAMMA}(33))$;

$M(34)=A L F A(29) * 2 /(K T(12) * \operatorname{GAMMA}(34))$;

$M(35)=A L F A(29) * 3 /(K T(13) * G A M M A(35))$;

$M(36)=A L F A(29) * 4 /(K T(14) * G A M M A(36))$;

$M(37)=A L F A(8) /(K T(15) * G A M M A(37))$;

$M(38)=A L F A(8) * 2 /(K T(16) * G A M M A(38))$;

$M(39)=A L F A(8) * 4 /(K T(17) * G A M M A(39))$;

$M(40)=A L F A(5) /(K T(18) * G A M M A(40))$;

$M(41)=A L F A(5) * 2 /(K T(19) * G A M M A(41))$;

$M(13)=A L T O T /(1 E O+G A M M A(13) *(M(33)+M(34)+M(35)+M(36)+M(37)+M(38)$

$+M(39)+M(40)+M(41)))$;

ALFA 13$), C 1=M(13) * G A M M A(13)$;

DO $I=33$ TO 41 ;

$M(I)=M(I) * C I$;

ALFAI I $=M(I) * G A M M A(I) ; \quad E N O$;

1* FE SPECIES * 1

Y14: IF CUNITS(17) <=OEI THEN GO TO Y15;

$M(70)=A L F A(4) /(K T(46) * G A M M A(70))$;

$M(71)=A L F A(4) * 2 /(K T(47) * G A M M A(71))$;

$M(72)=A L F A(4) * 3 /(K T(48) * G A M M A(72))$;

$M(73)=A L F A(4) * * 4 /(K T(49) *$ GAMMA $(73))$;

$M(74)=A L F A(8) /(K T(50) * G A M M A(74))$;

$M(75)=A L F A(8) * 2 /(K T(5)) * G A M M A(75)) ;$

$M(76)=A H 20 /(K T(52) * T E N P H * 3 *$ GAMMA (76));

$M(77)=A L F A(5) /(K T(53) * G A M M A(77))$;

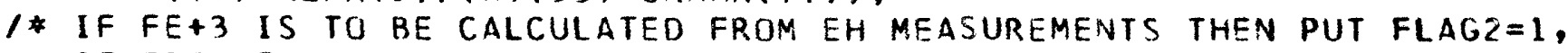
IF FRDM THF REACTION FE $+3+1 / 2 \mathrm{H} 2 \mathrm{O}+1 / 8 \mathrm{HS}-=\mathrm{FF}++1 / 8 \mathrm{SO} 4+9 / 8 \mathrm{H}+$ THEN FLAG2 $=0$ * 1

IF EHM $\angle 9 E O \&$ \&LAG2 $=1$ THEN DO;

$C l=1 E 1 *((E H M * F-L O G K T(296)) /(2.303 * R * T))$;

$M(18)=C 1 /$ GAMMA $(18) ;$ END;

ELSE IF CUNITS(32)=OEI THEN M(18)=OE1;

ELSE IF FLAG2 =0 THEN

$M(18)=($ ALFA $(5) * .125 * T E N P H * 1.125) /(K T(5) * \operatorname{SQRT}(A H 20) *$

ALFA $(100) * .125 * G A M M A(18))$;

$M(78)=A L F A(4) /(K T(54) * G A M M A(78))$;

$M(79)=A L F A(4) * 2 /(K T(55) *$ GAMMA $(79))$;

$M(80)=A L F A(4) * 3 /(K T(56) * G A M M A(80))$;

$M(81)=A L F A(4) * 4 /(K T(57) * G A M M A(81))$;

$M(82)=A L F A(5) /(K T(58) * G A M M A(82))$;

$M(93)=A L F A(5) * 2 /(K T(59) * G A M M A(83))$;

$M(84)=A L F A(8) /(K T(60) *$ ISAMMA $(84))$;

$M(85)=A L F A(8) * 2 /(K T(6)) * L A M M A(85))$;

$M(86)=A L F A(8) * 3 /(K T(62) * G A M M A(86))$;

$M(87)=A L F A(8) * 4 /(K T(63) *$ SAMMA $(87))$; 


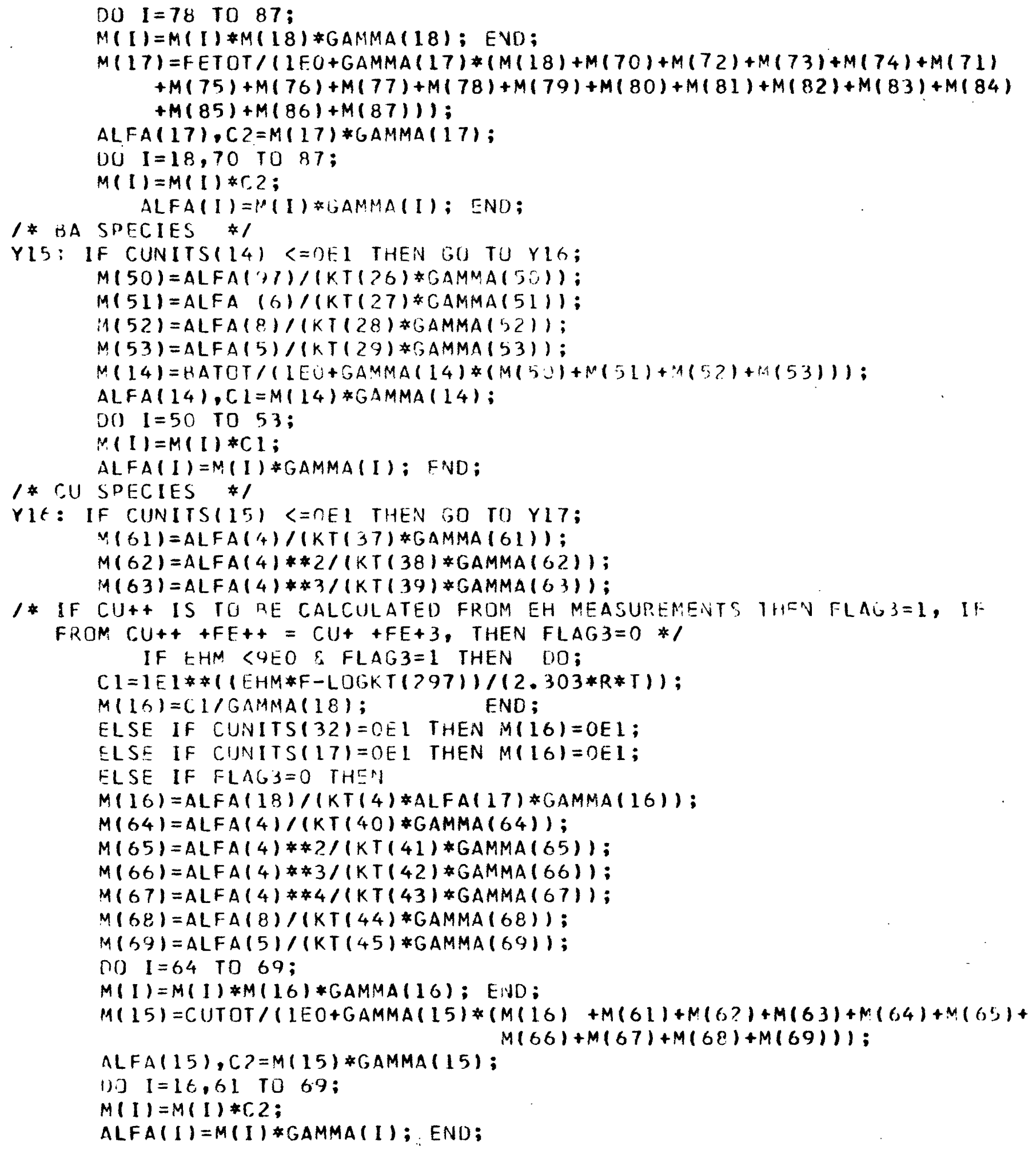




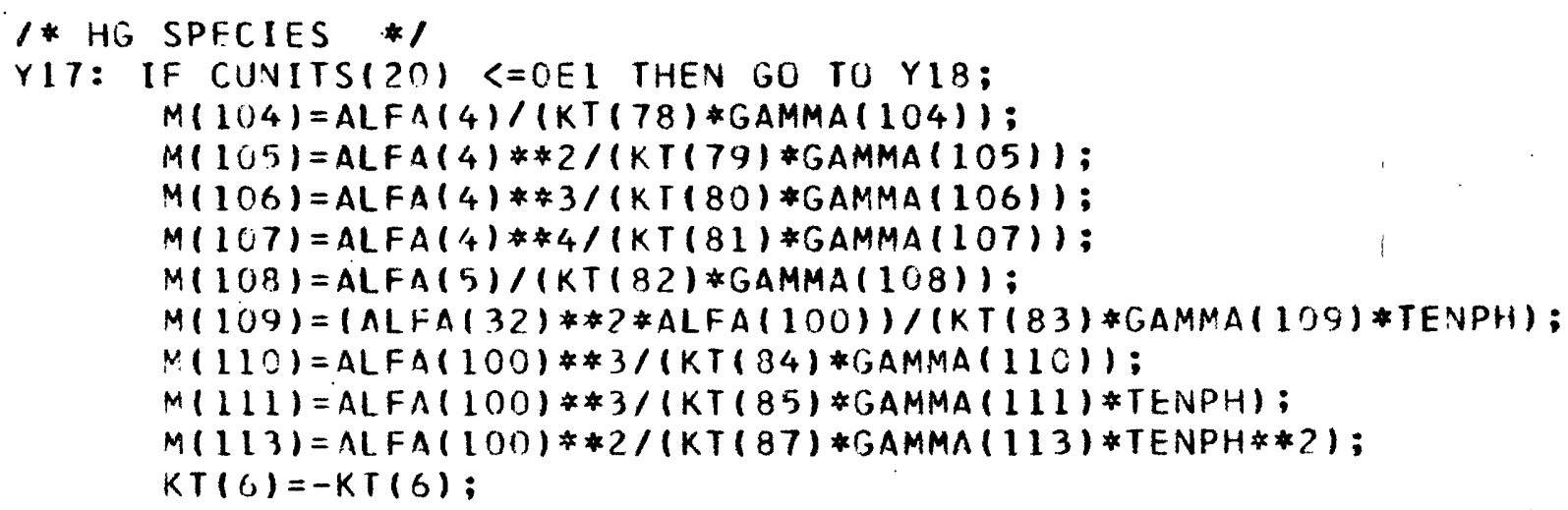




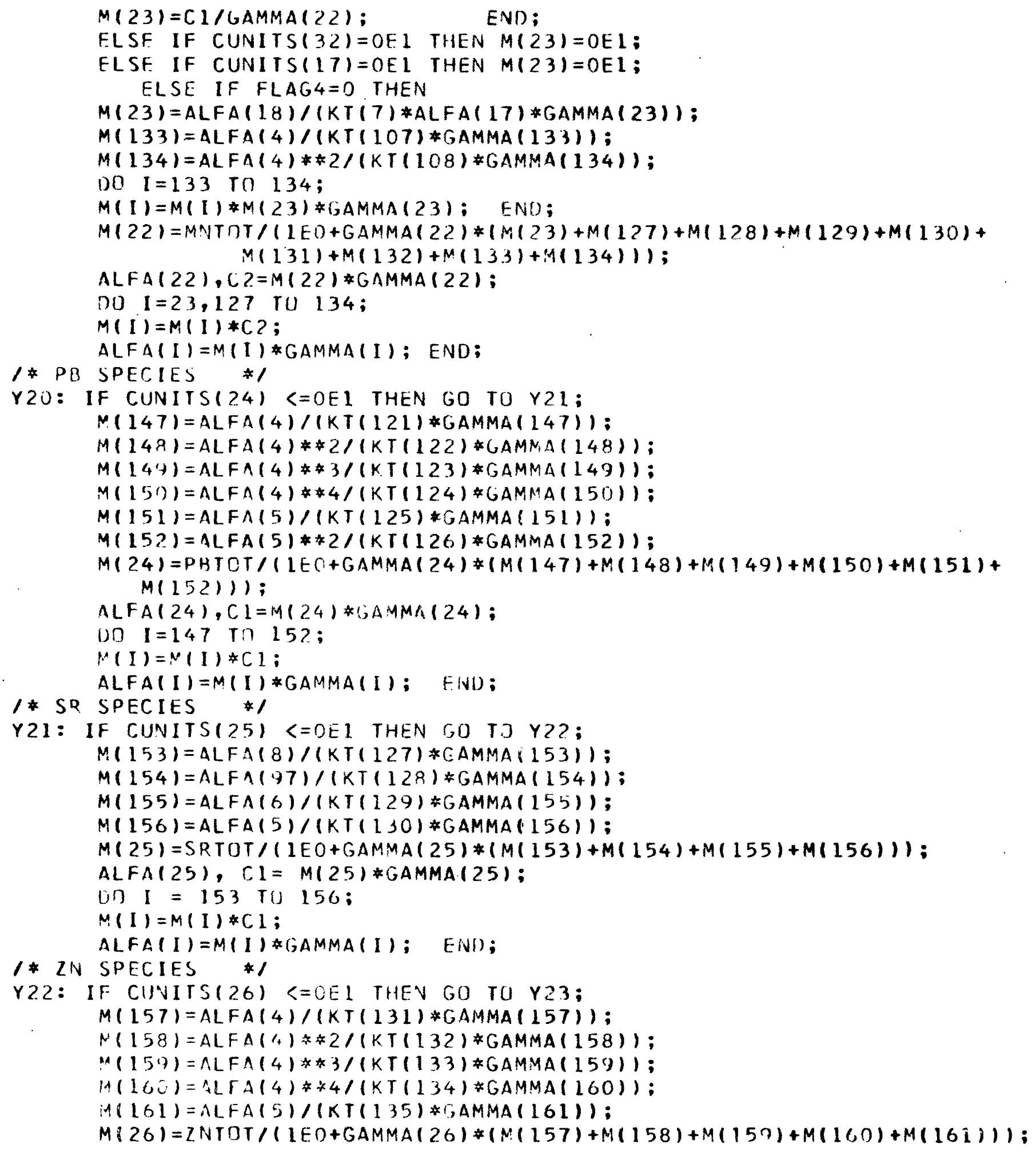


$A L F A(26), C 1=M(26) * G A M M A(26)$;

DO I $=157$ TO 161 ;

$M(I)=M(I) * C I$;

$A L F A(I)=M(I) * G A M M A(I) ; \quad E N D$;

* AS SPECIES *1

Y23: IF CUNITS(27) $\angle=$ DE I THEN GO TO Y24:

$M(48)=K T(8) / A L F A(8) *$ GAMMA $(48)$;

$M(91)=T E \cdot V P H /(K T(67) * G A M M A(91))$;

IF ALFA(17) $\rightarrow=O L 1$ THEN DO;

$M(49)=(A L F A(18) * 2 * A L F A(8) * 4) /(A L F A(17) * 2 * G A M M A(49)) ; E N D$;

$M(92)=$ TENPH $/(K T(68) *$ GAMMA (92));

M(93) =TENPH* $2 /(K T(69) *$ GAMMA (93));

$M(94)=T E N P H * 3 /(K T(70) *$ GAMMA $(94))$;

II) $I=92$ TO 94 ;

$M(I)=M(1) * M(49) * G A M M A(49): \quad E N() ;$

$M(27)=A S T O T /(1 F O+G A M M A(27) *(M(48)+M(91)+M(92)+M(93)+M(94)+$ $M(49) 1)$;

ALFA $(27), C l=M(27) *$ SAMMA $(27)$;

DO $I=48,49,91$ TO 34 ;

$M(I)=M(I) * C I$;

ALFAI I ) =M(I) GAMMAI I ); ENU;

* SUMMATION OF ANION SPECIES *1

Y24: $\quad S 1=M(6)+M(97)+M(50)+M(51)+M(54)+M(55)+M(119)+M(120)$

$+M(131)+M(137)+M(138)+M(134)+M(154)+M(155) ;$

$S 2=M(5)+M(40)+2 * M(41)+M(46)+2 * M(47)+M(53)+M(60)+M(69)+M(77)+M(82)$

$+2 * M(83)+M(102)+M(108)+2 * M(1 C 9)+M(110)+2 * M(111)+M(114)+$

$M(115)+M(118)+M(123)+M(132)+M(140)+M(141)+M(146)+M(151)+$

$M(156)+M(161)+2 * M(152)$;

$S 3=M(29)+M(33)+2 * M(34)+3 * M(35)+4 * M(36)+M(121)+M(95) ;$

$S 4=M(28)+M(57)+M(58)+M(59)+M(98)+M(99)+M(116)+M(124)+M(125)+$

$M(126)+M(142)+M(145)$;

$S 5=M(4)+M(42)+2 * M(43)+3 * M(44)+4 * M(45)+M(61)+2 * M(62)+3 * M(63)+M(64)$

$+2 * M(65)+3 * M(66)+4 * M(67)+M(70)+2 * M(71)+3 * M(72)+4 * M(73)+M(78)$

$+2 * M(79)+3 * M(80)+4 * M(81)+M(104)+2 * M(105)+3 * M(106)+4 *$

$M(107)+M(127)+2 * M(128)+3 * M(129)+4 * M(130)+M(133)+2 * M(134)$

$+M(136)+M(147)+2 * M(148)+3 * M(149)+4 * M(150)+M(157)+2 *$

$M(158)+3 * M(159)+4 * M(160)$;

ANALCU3 $=C 02 T$ I T $-4 E 0 * M(27)-3 E O * M(28)-M(37)-2 E 0 * M(38)-4 E 0 * M(39)-3 E 0 *$

$M(48)-8 E 0 * M(49)-M(52)-M(56)-M(68)-M(74)-2 F C * M(75)-M(76)-M(34)$

$-2 E C * M(85)-3 E 0 * M(86)-4 E 0 * M(87)-M(88)-2 E V * M(87)-M(90)-3 E 0 * M(+1)$

$-7 E 0 * M(92)-6 * M(93)-5 E 0 * M(94)-2 E 0 * M(98)-M(39)-M(100)-2 E 0 *$

$M(101)-M(102)-M(117)-M(122)-M(144)-M(153)$;

* ITEPATION TESTS *I

RBIT $=\cdot O \cdot B$;

IF $\mathrm{SI} \rightarrow \mathrm{OED}$ THEN ANALCO3=UEO;

ELSE IF ABS(S1-ANALCO3)>5E-3*ANALCO3 THEN $) 0$;

CO2TOT $=.5 F C *(M(6)+M(96)+M(97)) *(1 H O+A N A L C O 3 / 51)$;

PHIT $=\cdot 1 \cdot B$; END; 


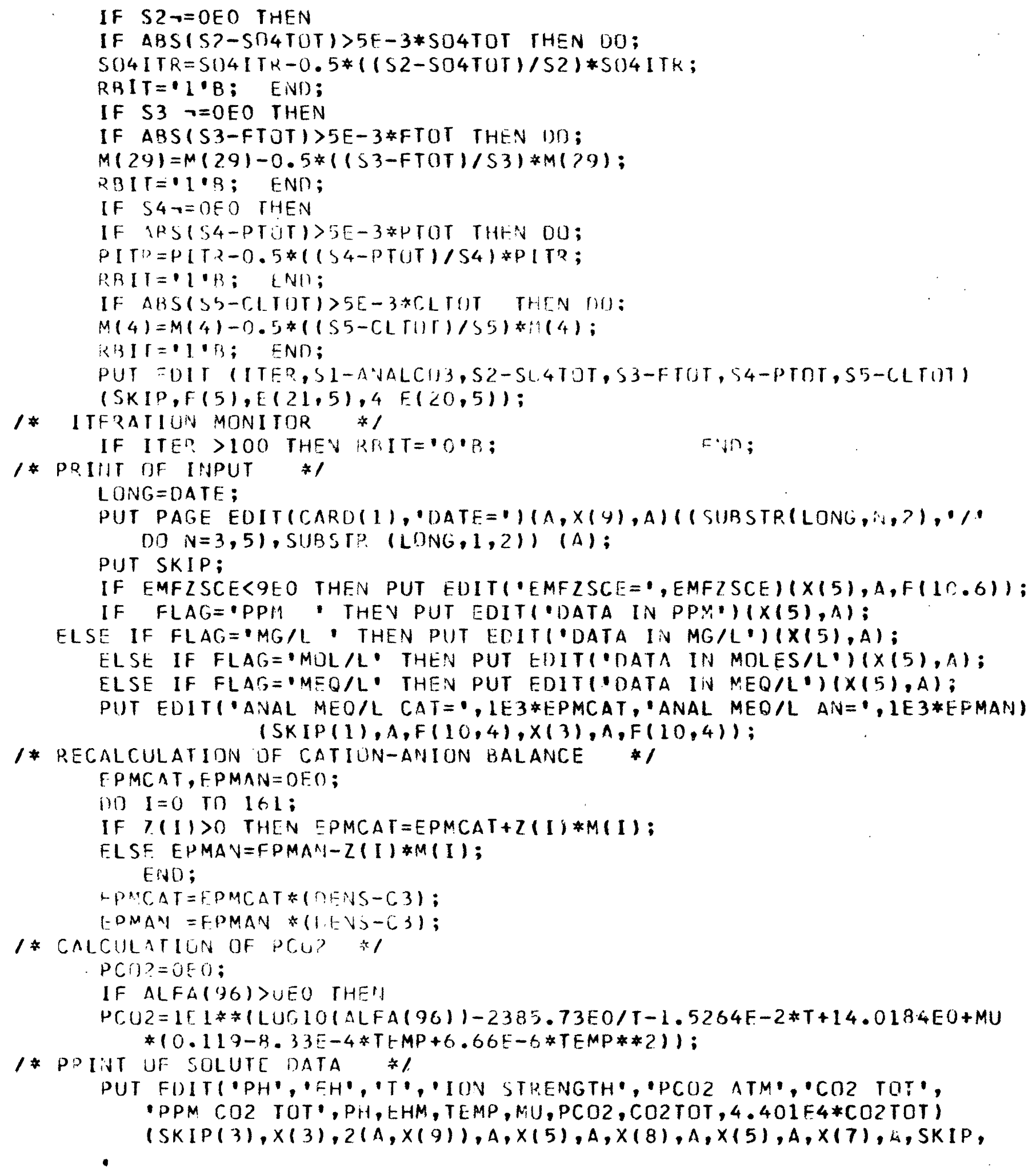


$F(6, ?), X(2), F(10,4), X(2), F(8,2), X(2), F(13,5), X(2), F(14,7)$, $X(2), F(13,6), X(2), F(13,6))$

'CALC MEQ/L CAT', 'CALC MEQ/L AN', PAGE1 (9), 'CO3CALC', PH2O ATM', 'DENSITY', 'TOS MG/L', IE3*EPMCAT, 1E3*EPMAN, AH?O,M(97), PH?O,DENS, $1 E 6 * C 3)(\operatorname{SKIP}(2), A, X(5), A, X(6), A, X(5), A, X(3), A, X(2), A$, $X(4), A, S K I P, F(12,3), X(7), F(12,3)$,

$F(11,4), E(17,4), 2(F(9,4)), F(13,2))$

('IUY', 'ANAL PPM', 'CALC PPM', 'ANAL MG/L', 'CALC MG/l', 'ANAL MOLAL' 'CaLC MULAL', 'Alfa', 'GaMma', 'P IUN') $(S K I P(2), X(9), A, X(9)$ , $A, \times(B), 4(A, \times(4)), A, \times(5), A, 2(\times(8), A))$;

PUT SKIP (?):

(I) $I=C$ TI) 161 ;

IF ALFA(I)> OEO THEN CI=-LUSBOO(ALFA(I)); [LSE CL $=0$ OD;

PUT SKIP EDIT(I,PAGFI(I),Z(I)) (F(3),X(2),A(9),F(3)):

IF CUINITS(I)>OFO \& FLAG= PPM - THEIN PUT EUITICUNITS(I)) $(F(13,4))$;

ELSE IF CUNITS(I)>NEO \& FLAG=MMG/L - THEN DG; CU =CUNITS(I) /DENS;

PUT EUIT $(C U)(F(13,4))$; END;

$S 1=1 E 3 * M(I) * G F W(I) *(D E N S-C 3) /[E-1 S$;

IF SI>OEO THEN PUT FOIT $(S 1)(C U L(30), F(13,4))$;

IF CUNITS(I) $>0 E O \&$ FLAG='MG/L THEN PUT EUITICUNITS(I))

$(C \cap L(43), F(13,4))$;

ELSEIF CUNITSII)>OEO \& FLAG=PPPM - THEN DO ;

CU $=$ CUNITS $(I) * D E N S$;

PUT EDIT (CU) (COL $(43), F(13,4))$; END);

$S 2=S 1 * D E N S$;

IF S2>OEO THEN PUT EDIT (S2) (CUL $(56), F(13,4))$;

IF ANALMII)>OEO TH:N PUT EUIT (ANALM(I))(COL(69), H(13,4));

IF $M(I)>$ OEO THEN PUT EDIT (M(I)) (CILL(2, $), 5(1,1,4)$;

IF ALFAII)>OEO THEN PUT EOIT (ALFA(I))(COL(3), $1(13,4))$; PUT EDIT (GAMMAII)) (COL $(108), F(12,6))$;

IF $C 1>0 E O$ THEN PUT EOIT $(C L)$ (CUL $(120), F(11,4))$; EN);

$1 *$

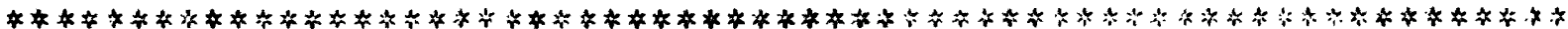

CALCULATION OF ION ACTIVITY PROUUCTS IN TI, SM, I I PQODUCT (AP) OF A MINEQAL WHICH CBITAINS A SPICIHS PIJT RIVEN IV THE. CHEMICAL ANALYSIS TIF THE WATER SAMPLF WILL BE '3LAING' .HIHEVER AIV ARBITRAOY VALUE MAY HE ASSIGNED TO THE CDNCFNTRATIIIM UF ANY DESIREU SPECIES.' THE SPECIES APPEARINI IN THE (AP) EQUATIONS ART O TO 6.9.9, 10,12 TO $18,20,22$ TO $29,97,100$.

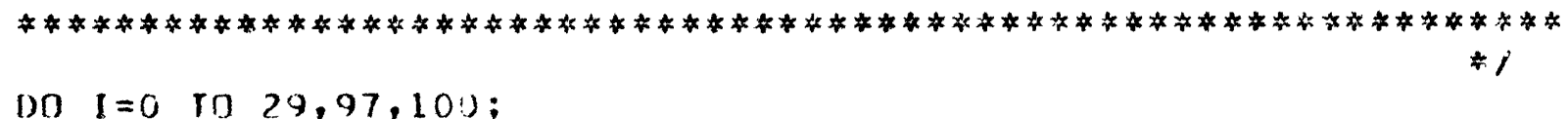


IF ALFAI I I >OEO THEN

$A L F A(I)=L O G 1 O(A L F A(1))$;

FLSE ALFAI I $)=-2 F 4$; END;

1* if YDU DO NOT WANT PRINT OUT OF MOLF RATIDS, LDG OF ACTIVITY RATIOS - gamMa CD2, 8DOT, a \& B THEN put ratio=1

IF RATIO=O THEN DO;

PUT SKIP(5) EDIT ('MOLE RATIOS BASEO ON ANALYTICAL MOLALITY',

'CL/C.A', 'CL/MG', 'Cl/Na ', 'CL/K', 'CL/AL',

'CL/FF', 'CL/SO4', 'CL/HCO3','CA/MG', SORT(CA)/NA')

$(A, \operatorname{SKIP}(2), 6(X(8), A), X(7), A, \times(6), A, X(5), A, \times(4), A)$;

$\mathrm{J}=1 ; \quad$ OO $\mathrm{I}=0,1,2,3,13,17,5$;

IF ANALM(I)>OEO THE S PUT EOIT (CLTOT/ANALMII)) (COL(J),E(13,4)); $\mathrm{J}=\mathrm{J}+13 ;$ FiND;

IF CU2TIT>OEO THEN PUT EUIT(CLTOT/CO2TIT) $(C O L(J), E(13,4))$;

IF AVALM(I) >OEO THEN PUT EI)IT (AVALM(O)/ANALMI I))

$(C O L(105), E(13,4))$;

IF ANALM( 2 ) $>0 E O$ THEN PUT EDITISQRT(ANALM(O))/ANALM(2))

$(C O L(118), E(13,4))$;

PUT SKIPI 2$)$ EDITI'NH3/NA', 'LI/NA', 'K/NA', 'MG/CA', 'SR/CA', 'BA/CA',

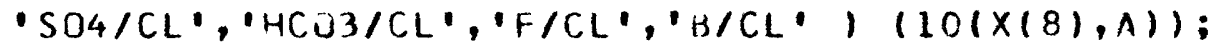

IF ANALM(2)>OEO THEN PUT SKIP EDIT (ANALM(31)/ANALM(?), ANALM(21); ANALM(2), ANALM(3)/AINALM(2) ) (X(2),3(E(13,4)) );

IF ANALM(O) OEO THEN PUT EDIT (ANALM(1)/ANALM(0), ANALM(25)/

ANALM(D), ANALM(14)/ANALM(O) $(3(E)(13,4))$;

IF ANALM(4) >OEO \& CU2TIT>OEO THEN PUT EDIT (ANALM(5)/CLTOT, CO2TIT/CLTOT,FTOT/CLTOT, BTUT/CLTOT) $(2(E(14,4)), 2(E(12,4)))$;

PUT SKIPI 2 ) EOITI'LOG UF ACTIVITY RATIOS', 'CA/H2', 'MG/HZ', 'NA/H' 'K/H', 'AL/H3', 'FE/H?', 'CA/MG', 'NA/K') (A,SKIP(2),X(7), S(A, $\times(12) 11 ;$

$C 1=-P H ; \quad J=1 ; \quad V=13 ;$

DOU $I=0,1,2,3,13,17 ; \quad C 2=A L F A(1)$;

IF CID-9EIS C2>-9EL THEN UOO;

IF I $=13$ THEN $\mathrm{C} 2=\mathrm{C} 2-3 E 0 * \mathrm{C} 1$;

ELSF IF $\mathrm{I}=21 \quad \mathrm{I}=3$ THFN $\mathrm{C} 2=\mathrm{C}_{2}-\mathrm{C}_{1}$;

ELSE C $22=C 2-2 E 0 * C 1$;

PUT EOIT (C2) (COL (J),F(N,4)); END;

IF I $=0$ THEN DO; $J=14 ; N=16 ; E N D$;

FLSE $J=J+16$; END;

IF ALFA(O)>-9FI\&ALFA(1)>-9E1 THEN PUT EOIT(ALFA(O)-ALFAII) $\because C O L$ $(97), F(16,4))$;

IF ALFA(?) >-9EIFALFA(3)>-9E THEIV PUT EOIT(ALFA(?)-ALFA(3))(COL $(114), F(16,4))$;

* * calculatiun uf the subsurfacf temperaturf isubi" of the SAMPLE FROM THF CHEMICAL DA1A * * *

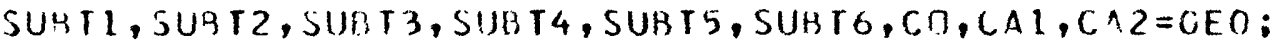

IF CUNITS $(11)>O E O$ THEN DO:

IF FLAG=IMG/L - THEN CO=CUNITS(11)/DENS;

ELSE IF FLAG = PPPM THEN CD=CUNITS(L1); 
SUBT $1=1.309 E 3 /(5.19 E 0-L O G 10(C O))-273.16 E 0$;

SUBT $2=1.57 .2 E 3 /(5.75 E O-L U G 10(C O))-273.16 E O ;$

SUBT $3=0.704 E 3 /(4.45 E 0-L O G 10(C O))-273.16 E 0$; END;

IF ANALM(2):>OEO \& ANALM( $31>0 E O$ THEN

SUBT $4=0.777 E 3 /(0.47 E O+L O G 10((A N A L M(2) / A N A L M(3))))-273.16 E 0$;

DO $I=0,2,3$;

IF ANALM(I)>CEO THEN

ANALM(I) =LחGIO(ANALM(I)); END; $\operatorname{ANALM}(0)=0.5 * A N A L M(0)$;

IF ABS(ANALM(O))>OEO \& ABS(ANALM(2))>OEU \& ABS(ANALM(3)) >OEO

THEN DO; PUT EOIT $($ 'LUG $(N A / K)+1 / 3 L O G(S Q R T(C A) / N A)='$, ANALM(2) - ANALM(3) + (1EO/3EO) * ANALM(O)-ANALM(2)),

- $L O G(N A / K)+4 / 3 L D G(S Q R T(C A) / N A)=\cdot$, ANALM(2)-ANALM(3)+(4E0/3EO)*

(ANALM(O)-ANALM(2)) (SKIP(2),A,E(10,3),X(5),A,E(10,3));

$C A)=A N A L M(2)-A N A L M(3)+(1 E 0 / 3 E 0) *(A) A L M(0)-A N A L M(2))$;

$C A 2=A N A L M(2)-A N A L M(3)+(4 E O / 3 E 0) *(A N A L M(0)-A N A L M(2))$; END;

IF $\triangle R S(C A 1)>0 E O \&$ \& $A B S(C A 2)>O E 0$ THE IN DO;

SUB T $5=1.656 E 3 / 12.258 E 0+C A 1)-273.16 E 0$;

SUBT $6=1.656 E 3 / 1 ? .258 E 0+C A 21-273.16 E 0 ; \quad E N D ;$

PUT FOITI'SUBSUR.FACE TEMPERATURE (OC) FROM CHEMICAL DATA',

- QTZ TEMP (CONDUCTIVE) =', SUBT 1, 'OTZ TEMP (ADIABATIC) =',

SUBT?."AM.SILICA TEMP =', SUBT3, 'LOG(NA/K) TEMP =', SUBT4,

' LUG $(N A / K)+1 / 3 L U G(S U R T(C A) / N A)$ TEMP = ', SUBT5,

- LOG(NA/K)+4/3LOG(SORT(CA)/NA) TEMP=", SUBT6)

(SKIP(3),A,SKIP(2),A,F(10,1),X(5),A,F(10,1),

$S K I P(1), A, F(10,1), X(5), A, F(10,1)$,

SKIP(1),A,F(10,1),X(5),A,F(10,1));

PUT EOIT "IF THE SPPING IS BOILING OP STEAM IS LUST DUPING',

- kODUCTION THEN SElect QTz TEMP aDIABATIC Else',

- select wiz temp CONDUCTIVE', 'am.silica temp should',

- he COISIDERED If SAMPLE IS SATUP.ATED WITH AM.SILICA',

- I.E. IF CELG OF MIN.NO.275 IS PIISITIVF" "NA/K TEMP",

- IS USEFUl if CUINC. Uf CA IS LOW ("UPE DECS) VS itA',

-USE - -4/3LOG-- TEMP IF <100 ELSF. USE--1/3- TEMP',

- pean fournier \& TRUESDELL 1973')

END;

$(S K I P(2), 3(A)$, SKIP, 3(A),SKIP, $(A)$, SKIP,A,SKIP,A):

1* aCtIVITY products of phases *

$A P(138)=A L F A(2)+A L F A(18)+2 E O * A L F A(10)+4 E O * P H-2 E O * L H 20 ;$

$A P(139)=A L F A(12)+A L F A(17)-A L F A(18)$;

$A P(140)=2 F O * A L F A(12)+A L F A(10 C)+P H$;

$A P(141)=A L F A(12)+A L F A(4)$;

$A P(142)=A L F A(3)+1 L F A(13)+3 E O * A L F A(10)+4 E O * P H-4 E O * L H 20$;

$A P(143)=2 E O * A L F A(0)+A L F A(1)+2 E O * A L F A(16)+6 E C * P H-L H 2 O$;

$A P(144)=A L F A(2)+A L F A(13)+3 E O * A L F A(10)+4 E O * P H-4 E O * L H 20$;

$A P(145)=\Lambda L F A(2)+A L F A(13)+3 E O * A L F A(10)+4 E O * P H-4 E O * L H 20$;

$A P(146)=A L F A(3)+3 E O * A L F A(13)+2 E O * A L F A(5)+6 E O * A L F A(8)$;

$A P(147)=A L F A(2)+A L F A(13)+2 E O * A L F A(10)+4 E O * P H-L H 20$;

$A P(148)=2 F O * A L F A(13)+A L F A(10)+L H 2 O+6 E O * P H$; 


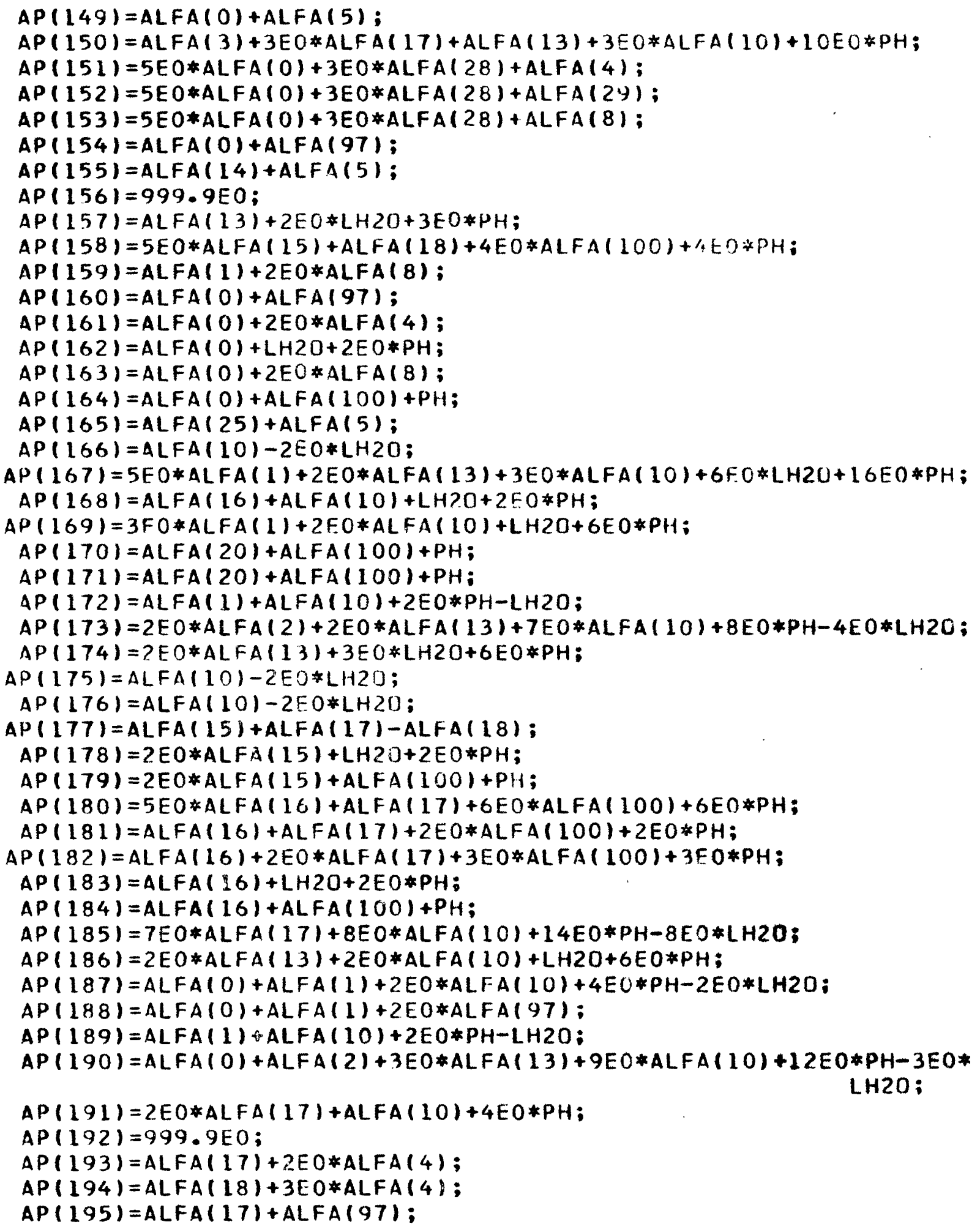




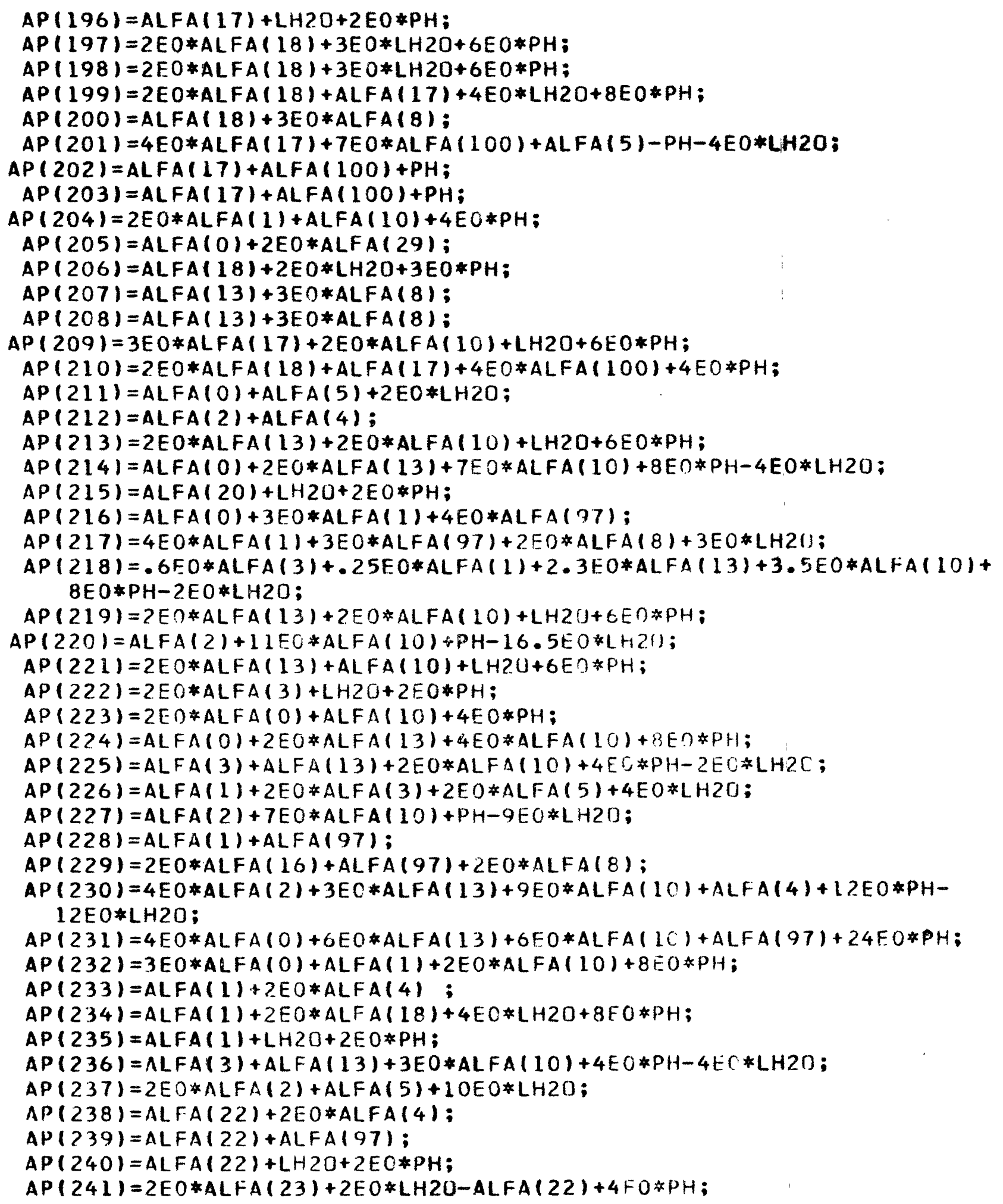


$A P(242)=A L F A(22)+A L F A(100)+P H$

$A P(243)=A L F A(0)+A L F A(1)+A L F A(10)+4 E 0 * P H$;

$A P(244)=.167 E 0 * A L F A(0)+2.33 E 0 * A L F A(13)+3.67 E 0 * A L F A(10)+7.324 * P H$ $-2.678 E 0 * L H 20$;

$A P(245)=.33 E 0 * A L F A(3)+2.33 E 0 * A L F A(13)+3.67 E O * A L F A(10)+7.32 E 0 * P H-$ $2.68 *$ LH2O;

$A P(246)=.167 E 0 * A L F A(1)+2.33 E O * A L F A(13)+3.67 E O * A L F A(10)+7.32 E 0 * P H$ $-2.678 E 0 *$ LH2O;

$A P(247)=.33 E 0 * A L F A(2)+2.33 E 0 * A L F A(13)+3.67$ EO *ALFA $(10)+7.32 E 0 * P H$ $-2.678 E O * \mathrm{LH} 20$;

$A P(248)=999.9 E 0$;

$A P(249)=999.9 F O$;

$A P(250)=A L F A(0)+2 E O * A L F A(13)+10 E O * A L F A(10)+8 E O * P H-9 E O * L H 20$;

$A P(251)=A L F A(3)+3 E O * A L F A(13)+3 E O * A L F A(10)+10 E 0 * P H$;

$A P(252)=2 E 0 * A L F A(2)+L H 2 O+2 E O * P H$;

$A P(253)=2 E 0 * A L F A(2)+A L F A(5)$;

$A P(254)=A L F A(2)+A L F A(6)$;

$A P(255)=2 E 0 * A L F A(2)+A L F A(97)+10 E O * L H 20 ;$

$A P(256)=2 E 0 * A L F A(2)+A L F A(97)+L H 20$;

$A P(257)=A L F A(2)+A L F A(13)+A L F A(10)+4 E O * P H$;

$A P(258)=A L F A(1)+A L F A(97)+3 E O * L H 2 U$;

$A P(259)=999.9 E 0$;

$A \cdot P(260)=999.9 E 0$;

$A P(261)=A L F A(24)+$ ?EO $* A L F A(4)$;

$A P(262)=A L F A(24)+A L F A(97)$;

$A P(263)=A L F A(24)+L H 2 O+2 E O * P H$;

$A P(264)=A L F A(24)+L H 20+2 E O * P H$;

$\triangle P(265)=A L F A(24)+A L F A(100)+P H$;

$A P(266)=A L F A(24)+A L F A(5)$;

$A P(267)=.5 F O * A L F A(2)+.5 E 0 * A L F A(3)+A L F A(13)+3 E(0 * A L F A(10)+4 E O * P H$ $-3 E O * L H 2 D$

$A P(268)=A L F A(3)+3 E O * A L F A(1)+A L F A(13)+3 E O * A L F A(10)+2 E O * A L F A(29)$

$+8 E O * P H-2 E O * L H 2 U$;

$A P(269)=A L F A(0)+2 E 0 * A L F A(13)+2 E O * A L F A(10)+8 E 0 * P H ;$

$A P(270)=2 E 0 * A L F A(0)+2 E O * A L F A(13)+3 E O * A L F A(10)+1 C E 0 * P H$;

$A P(271)=2 E 0 * A L F A(13)+4 F O * A L F A(10)+6 E 0 * P H-4 E O * L H 20$ :

$A P(2.72)=A L F A(10)-2 E O * L H 20$;

$A P(273)=A L F A(3)+A L F A(13)+3 E 0 * A L F A(10)+4 E O * P H-4 F()+L H \geq 1)$;

$A P(274)=2 E O * A L F A(1)+3 F O * A L F A(10)+4 F O * P H-2 E O * L H)(1)$

$A P(275)=A L F A(10)-2 E O * L H 20$;

$A P(276)=A L F A(10)-2 E O * L H 2 O$;

$A P(277)=$ ?.EO*ALFA $(13)+A L F A(10)+L H 20+6 E O * P H$;

$A P(278)=A L F A(1)+2 E 0 * A L F A(13)+4 E 0 * L H 2 U+8 E 0 * H H$;

$A P(279)=A L F A(? 5)+A L F A(97)$;

$A P(280)=A L F A(18)+A L F A(28)+2 E O * L H 20 ;$

$A P(281)=A L F A(3)+A L F A(4)$;

$A P(292)=3 E O * A L+A(1)+4 E O * A L F A(10)+6 E O * P H-4 F(* 1)+1) ;$

$A P(283)=2 E O * A L F A(0)+5 E O * A L F A(1)+8 E O * A L F A(10)+14 E 0 * P H-8 L O * L 20$; 
$A P(284)=3 E O * A L F A(2)+A L F A(6)+A L F A(97)+2 E O * L H 20 ;$

$A P(285)=A L F A(0)+2 E 0 * A L F A(13)+4 E O * A L F A(10)+8 E 0 * P H-2 E 0 * L H 20$;

$A P(286)=A L F A(14)+A L F A(97)$;

$A P(287)=A L F A(0)+A L F A(10)+2 E O * P H-L H 20$;

$A P(288)=A L F A(26)+A L F A(97)$;

$A P(289)=A L F A(26)+L H 20+2 E O * P H$

$A P(290)=A L F A(26)+A L F A(100)+P H$;

$A P(291)=A L F A(26)+A L F A(5)$;

$A P(292)=2 E O * A L F A(0)+3 E 0 * A L F A(13)+3 E O * A L F A(10)+L H 20+13 E O * P H$;

$A P(293)=3 E 0 * A L F A(17)+2 E O * A L F A(28)+8 E O * L H 20$;

$A P(294)=999.9 E 0$;

$A P(295)=999.9 E 0$;

PUT PAGE EDIT (CARD(1)) (A)

('PHASE','AP', KT ',LLg AP', 'LOG KT', 'AP/KT', 'Delg',

- LOG AP/KT'I

$(\operatorname{SKIP}(2), X(6), A, X(8), A, X(12), A, X(9), A, X(6), A, X(8), A, X(9), A$,

$X(6), A)$;

PUT SKIP (2);

DO I $=137$ TO 221,223 TO 295;

IF LOGKT(I) > 6. OE2 THEN LOGKT(I) $=5.9999 E 1$;

IF LOGKTII) >-7.OEI THEN DU;

$K T(I)=1 E I *(L O G K T(I))$;

$\mathrm{C}_{1}, \mathrm{C} 2_{2}=0 \mathrm{OEO}$;

DO $I=138$ TO 2.95 ;

$C 2=A P(1) ;$

PUT SKIP EDITII,PASE2(I),LUGKT(I)) (F(3), X(1),A,COL(57),F(9,4));

IF KT(I)>OFO THEN PUT SKIP(O) EDIT(KT(I)) (COL(30),E(1),4));

IF KT(I) $=0$ OEO THEIN PUT SKIP(O);

IF $\triangle B S(C 2)<5 F 2$ THEN DO;

PUT EDIT (C2) (COL $(45), F(9,4))$;

IF LOGKTII) $7=5.9999 E 1$ THEN DU;

$C 1=C 2-\operatorname{LOGKT}(1)$;

PUT EDIT $(2.302585 E 0 * R * T * C 1, C 1)(C O L(85), F(9,4), F(13,4)) ; \quad$ END;

IF $A B S(C 2)<75 E O$ THEN DO; C2=1E1*C2;

PUT SKIP(O) EDIT (C2) (COL $(15), E(11,4))$;

IF ABS (C2)>75EO THEN PUT SKIP(O);

IF KT(I)>OEO \& LOGKT(I) $=5.9999 E 1$ THEN PUT EDIT(C2/KTII)

END; END; FND;

$(\operatorname{COL}(69), E(12,4))$;

PUT SKIP(5) EOITI* DUMMY VALUE FUR LUGKT $=59.9990, K T=9.9770 E+59 * * 1)$ $(X(20), A)$;

GO TO START;

* declare statements *

DCL LONG CHAR (800) VAR,CARD(10) CHAR(80), FLAG CHAR(5), TABLES

FILE.

(PAGE 1 (0: 161), PAGE2(299)) CHAR (8),

( J,MJ,I, ITER,N,RATIO, INFORM )

FIXED BIN (31), RBIT

$B I T(1),(A, A H 2 O, D F N S, A N A L C O 3, L H 2 O, S O 4 I T R, B, C, C 1, C 2, C 3, F H M$,

EHMC, EMFZSCE, EPMAN, EPMCAT,F,CU, PITR, CO3CALC, MU, MUHALF,PCO2, 
PH, CATOT, MGTOT, NATOT, KTUT, CLTOT, SO4TOT, HCO3TOT, SITOT, AGTOT, AL TOT, BATOT, CUTOT, FETOT, HGTOT, LITOT, MNTOT, PBTOT, SRTOT, ZNTOT, ASTOT, PTOT, FTOT, BTOT, NH3TOT, H2STOT, COZTIT, CO2TOT, TENPH, R, T, TEMP,S1,S2,S3,S4,S5,ALFA (0:161),M(0:161), ANALM(O:161), CUNITS(0:161), GAMMA $(0: 161)$, TK(11),LKT(299,11)) FLOAT(16), (DHA (0:161), GFW(0:161),LOGKT(299), KT(295), AP(138:295), GAMACO2 $(0: 3,10), G(0: 3,10), \operatorname{TCO} 2(10), M N A C L E, B D O T, B D A T(10)$, SUBT 1, SUBT2, SUBT 3, SUBT4, SUBT5, SUBT6, CO, CA1, CA2, GT1,GT2,GTM,PH20, PH2OC1, PH2OC2, LOG1OPH20) FLOAT (16), ( $2(0: 161), F L A G 1, F L A G 2, F L A G 3, F L A G 4, F L A G 5)$ FIXEO BIN(31);

EOF: END SOLMNEQ; 


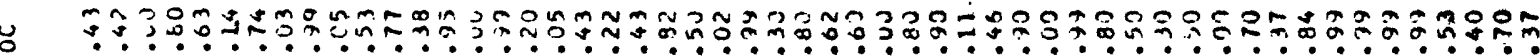

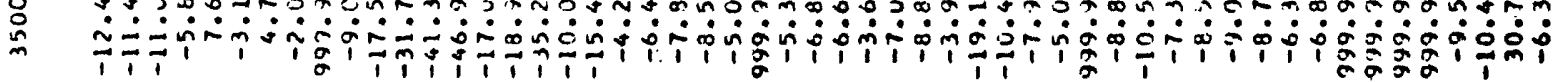

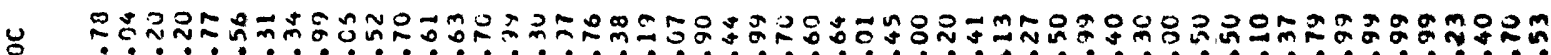

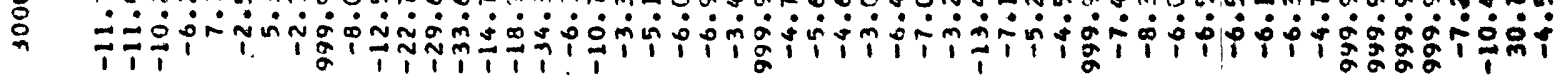

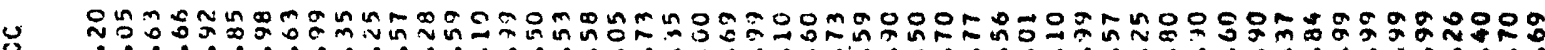

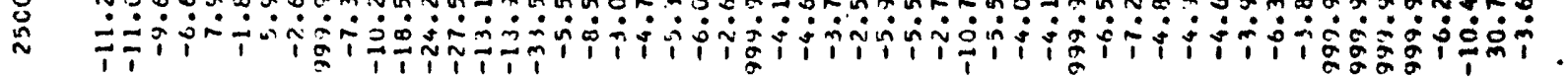

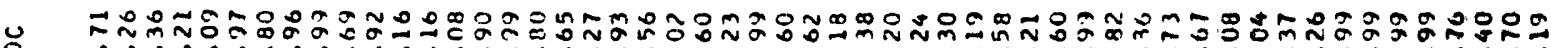
O T

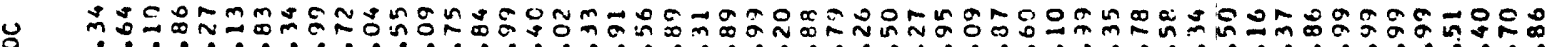

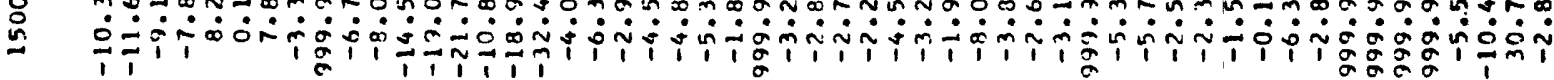

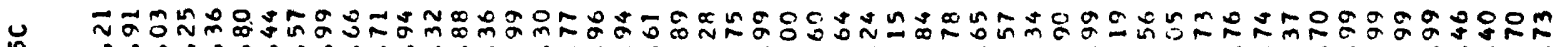

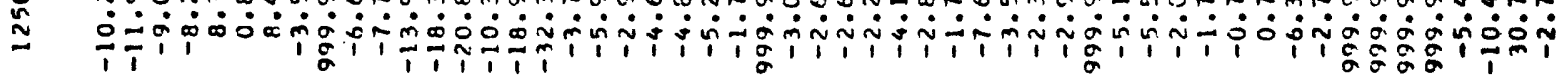

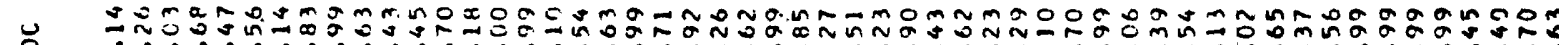
-

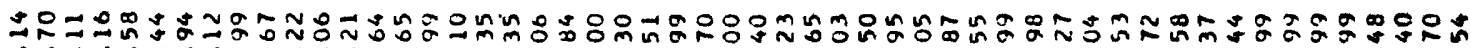

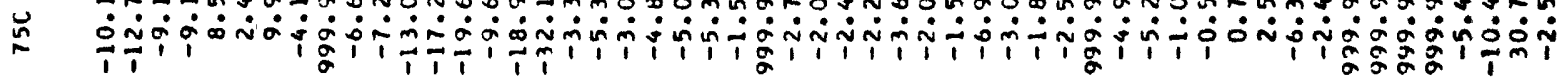

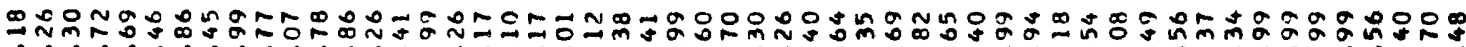

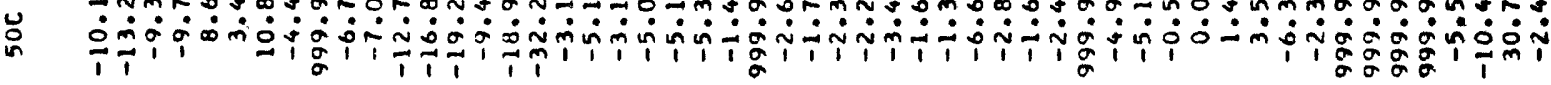

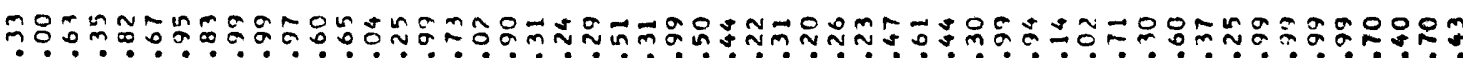

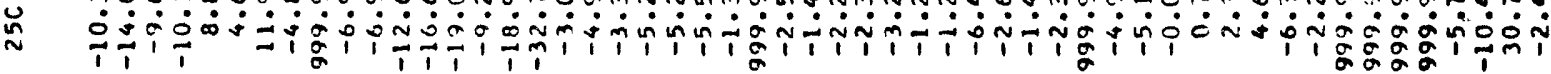

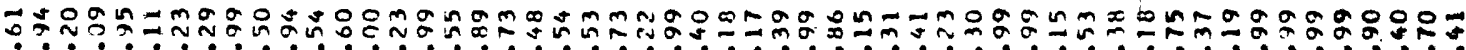

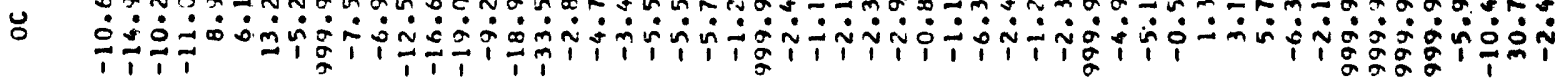
岁

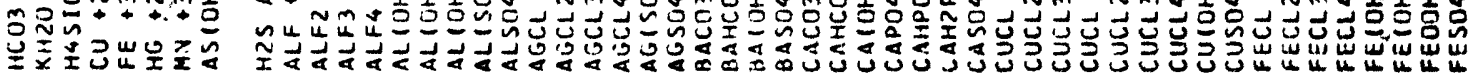

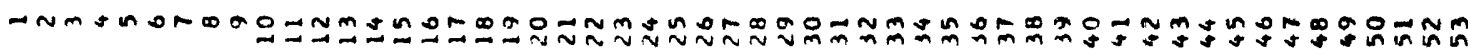




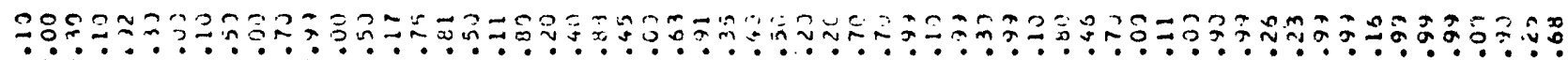

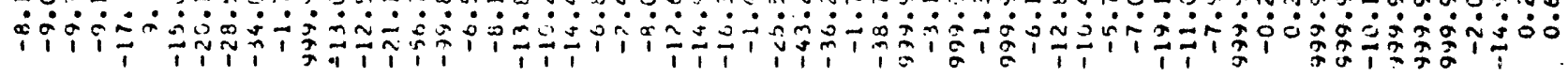

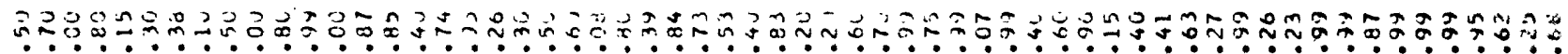

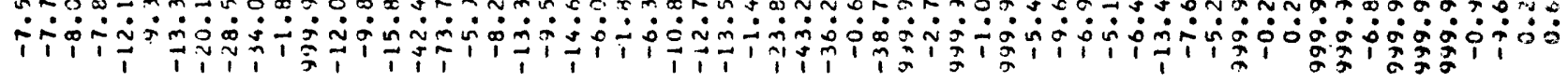

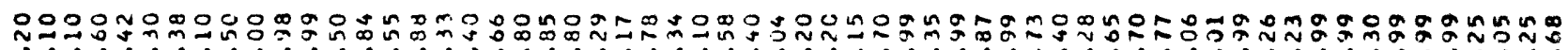

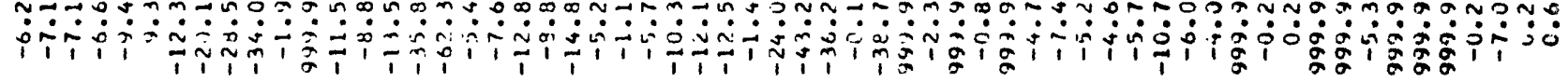

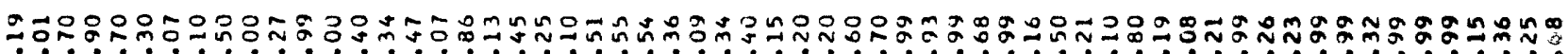
जिए人

里눘

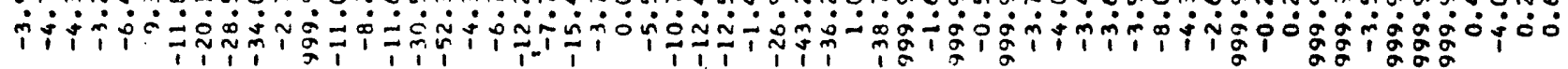

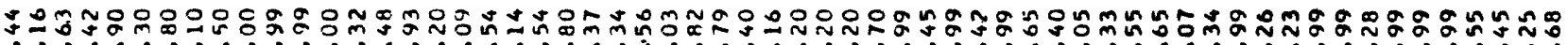

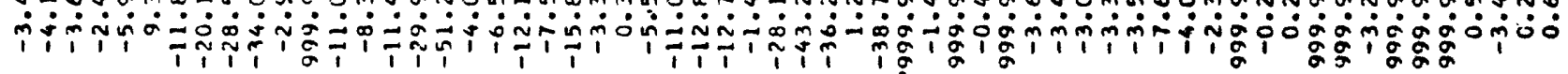

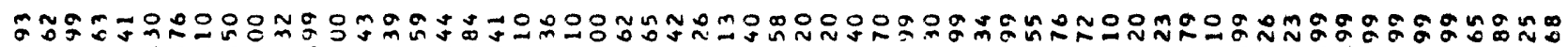
نि

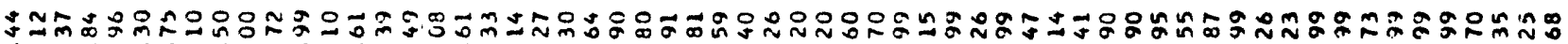

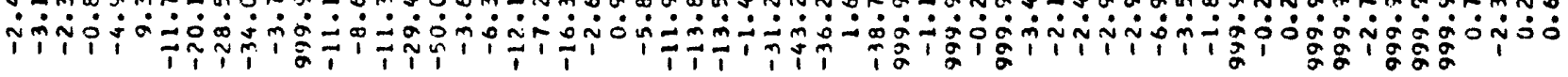

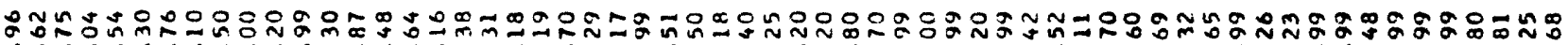

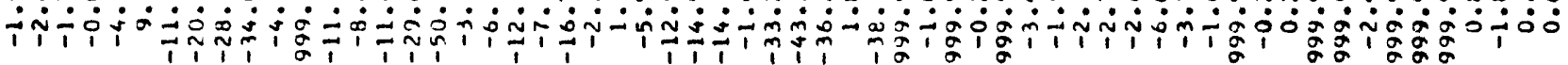

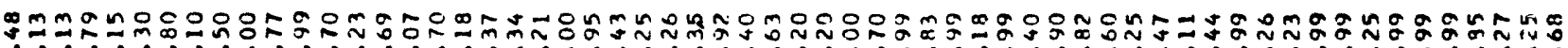
१িि

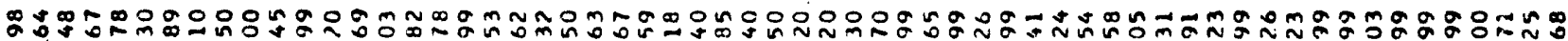
iी

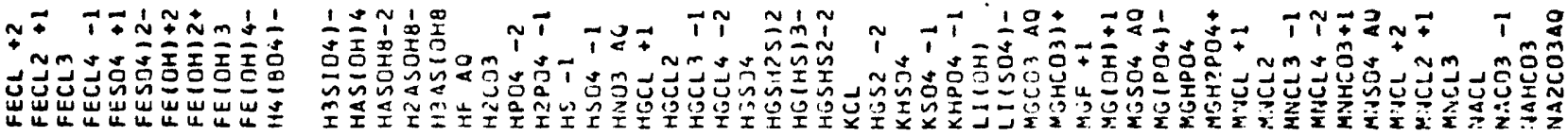

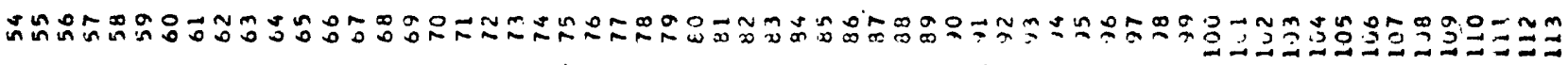




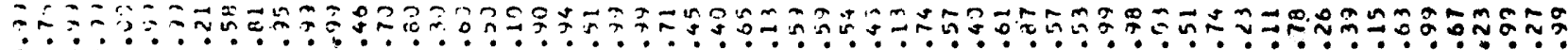

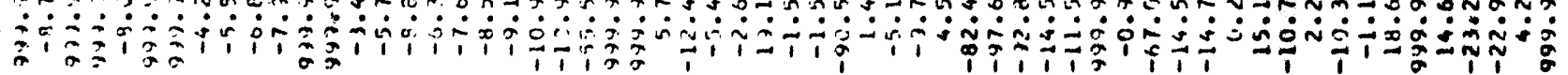

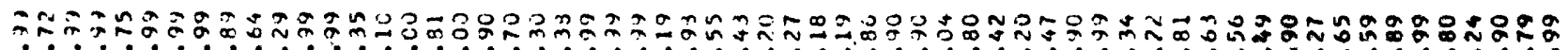
की

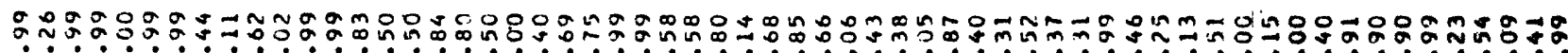

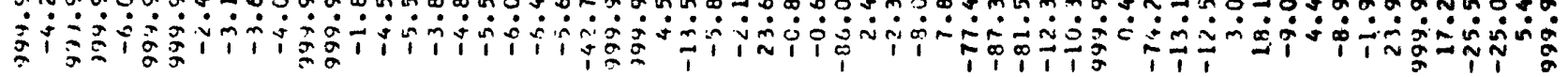

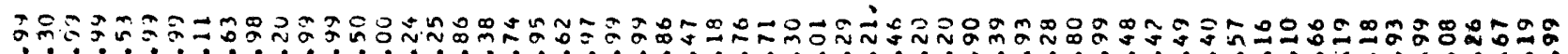

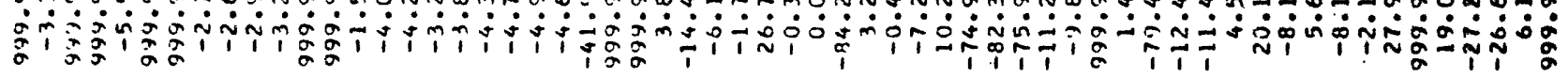

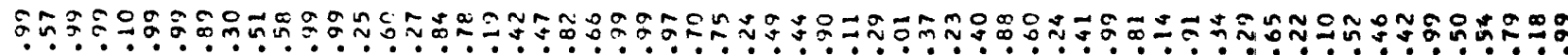

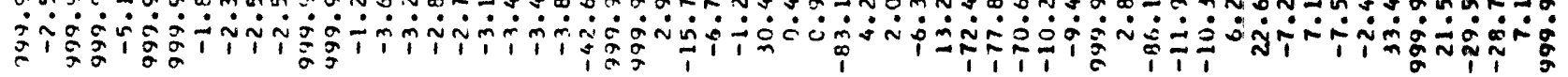

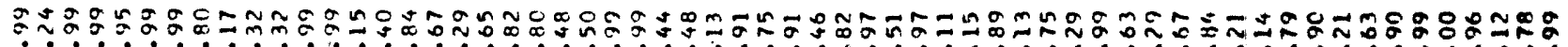

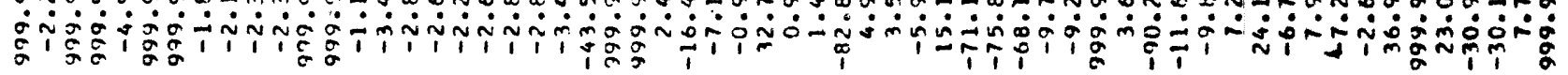

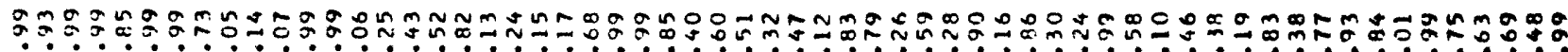

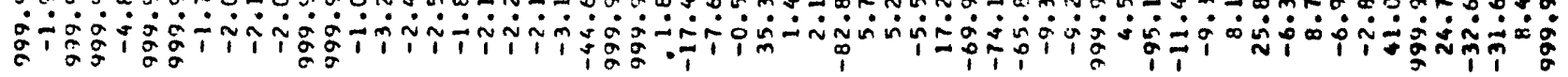

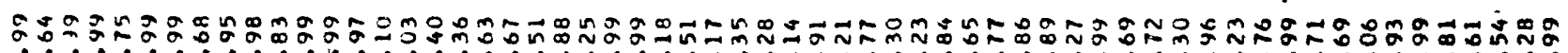

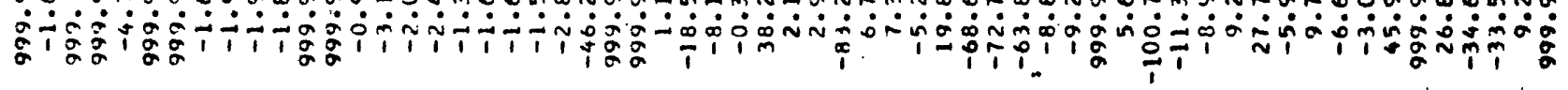

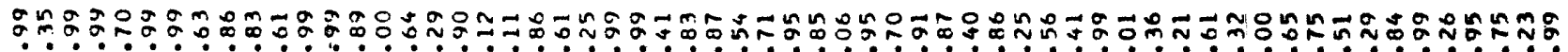

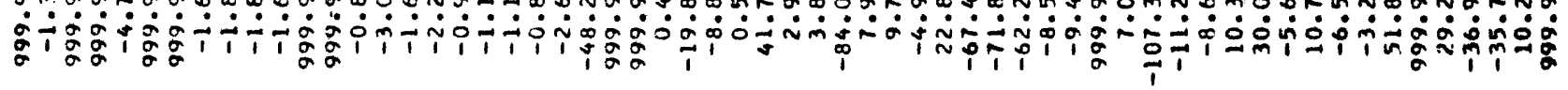

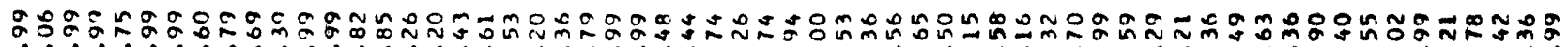

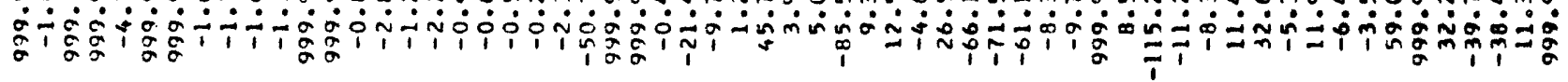

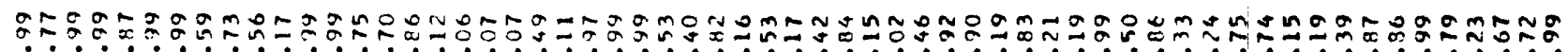

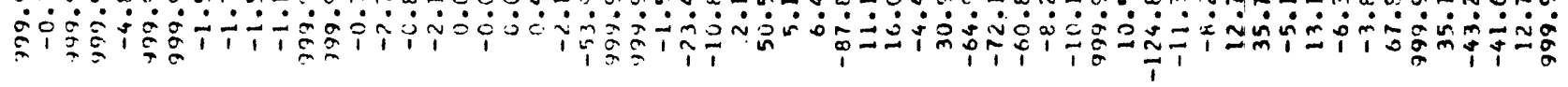

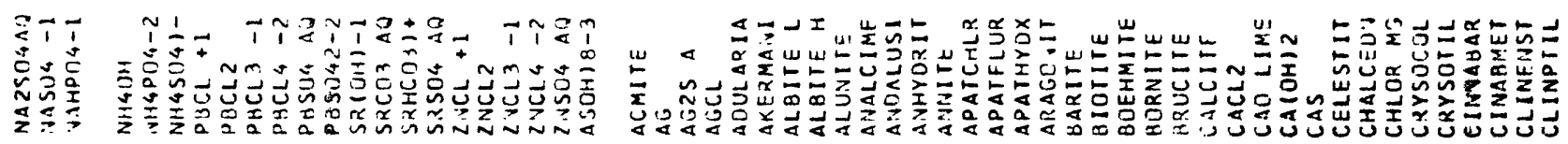

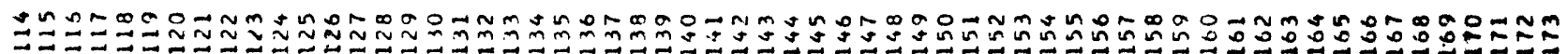




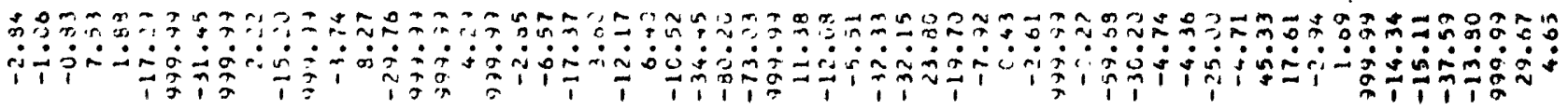

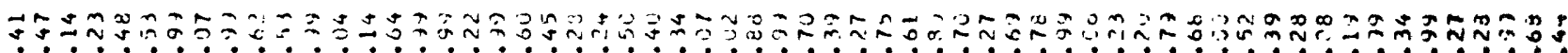

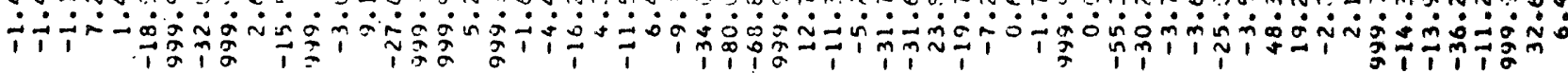

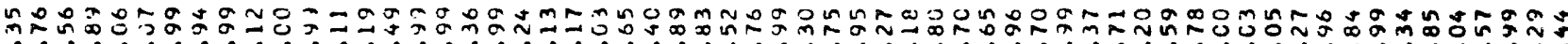

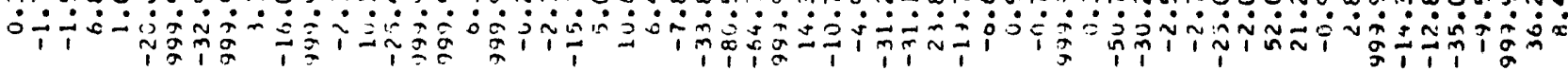

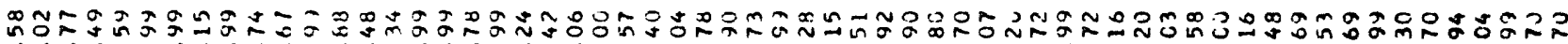

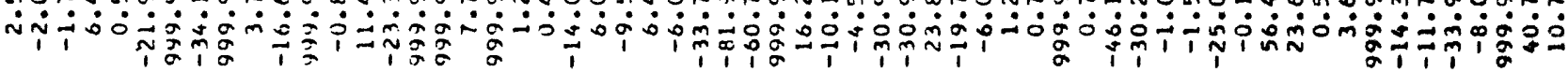

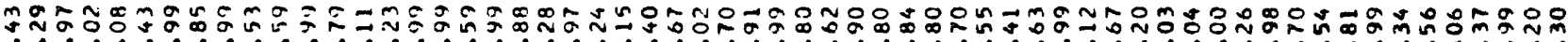

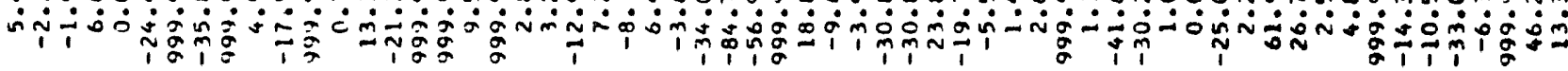

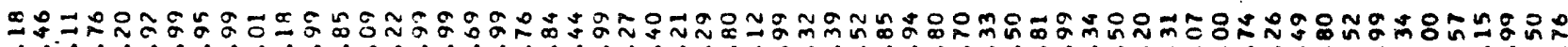

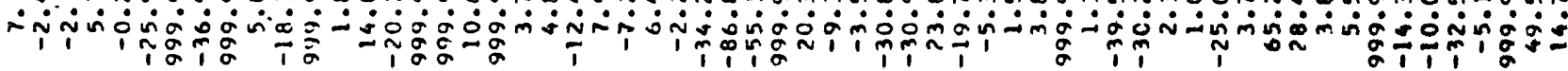

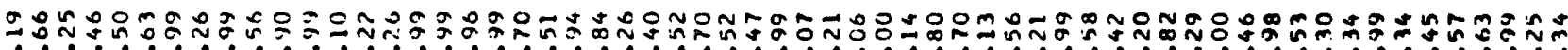

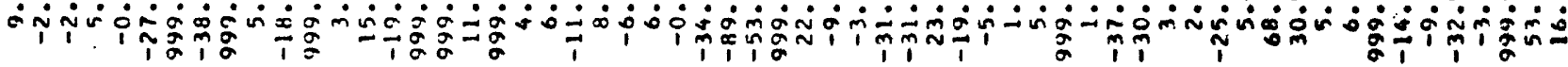

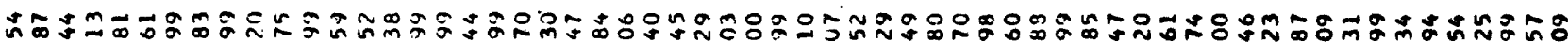

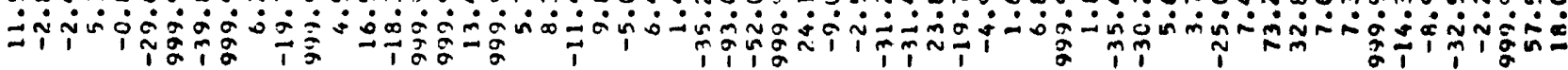

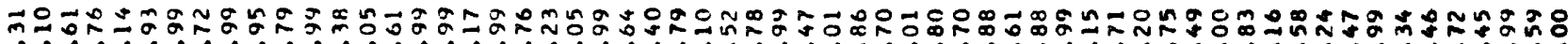

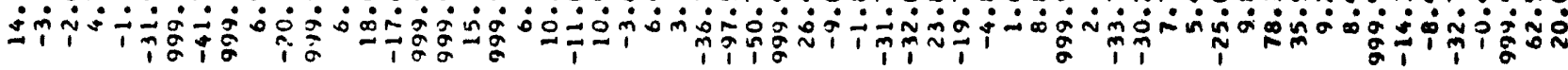

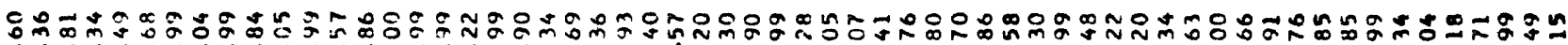

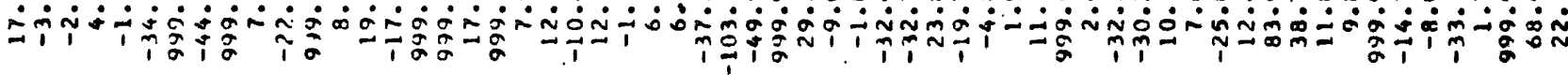

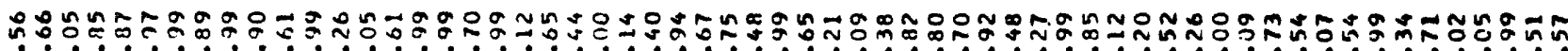

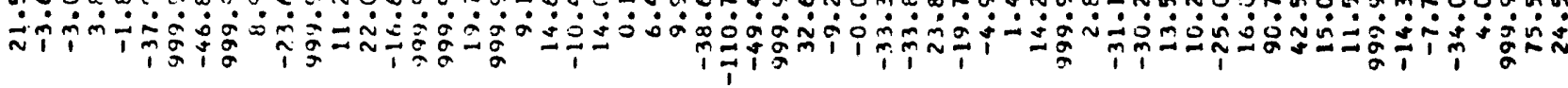

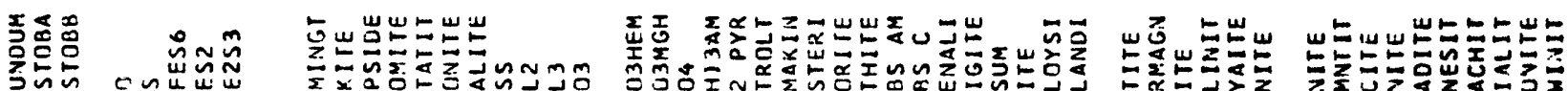

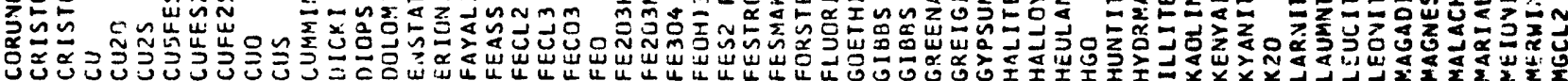

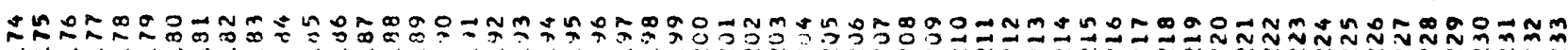


ง

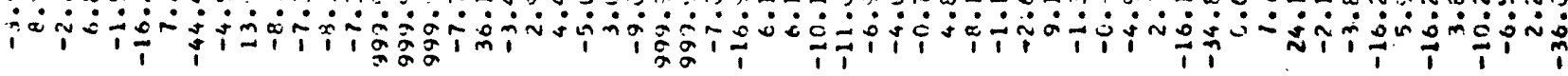

คั.

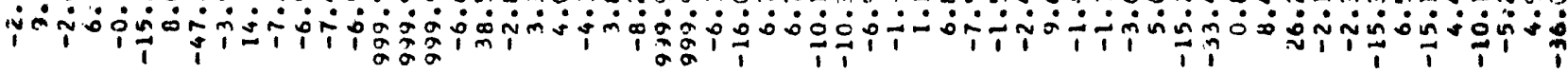

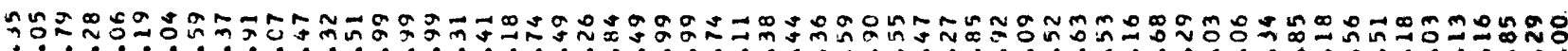

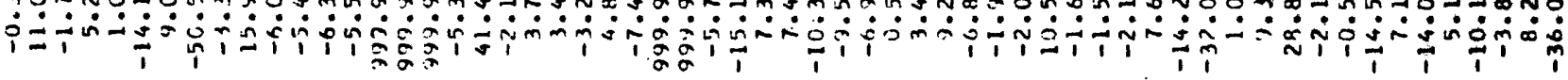

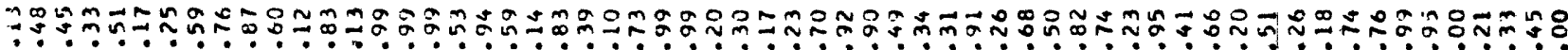

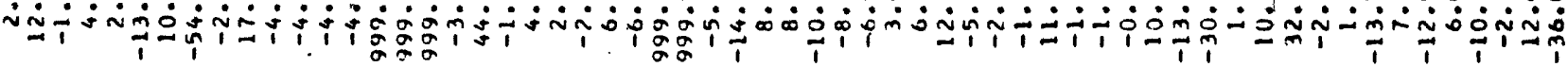

ก๊

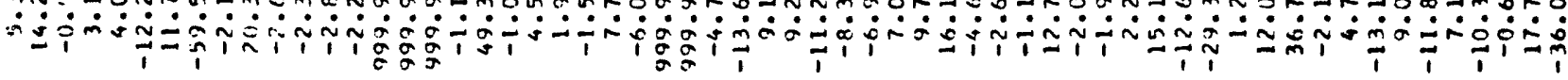

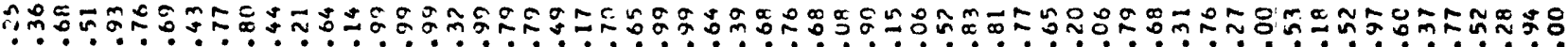

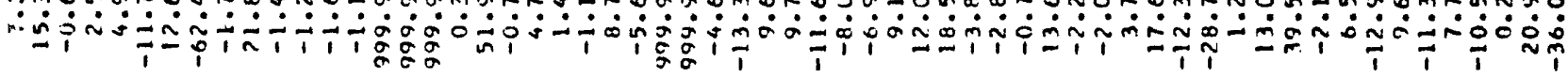

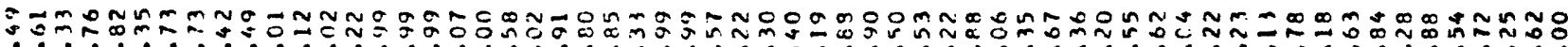

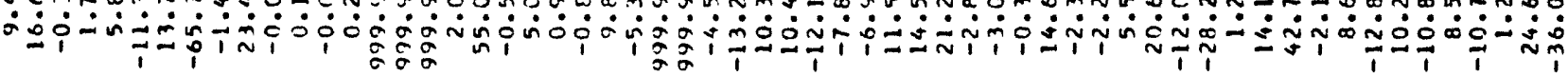

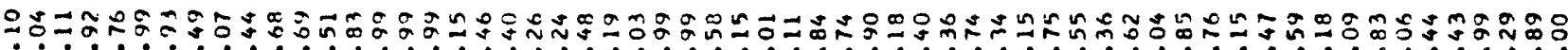

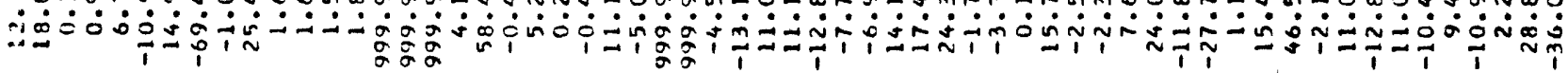

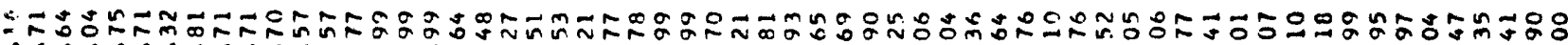

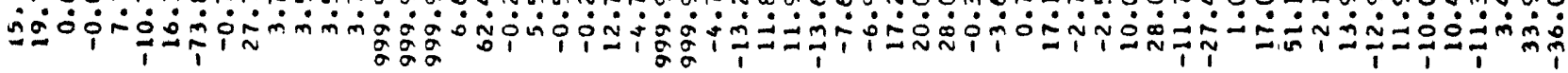

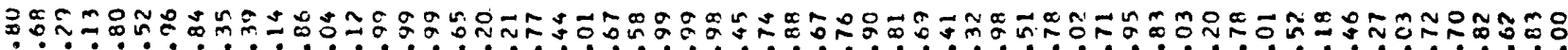

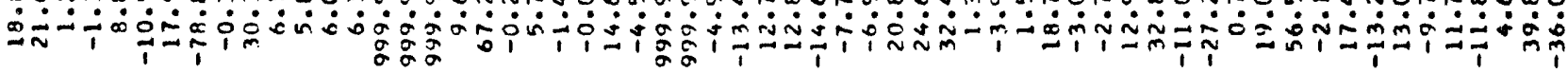

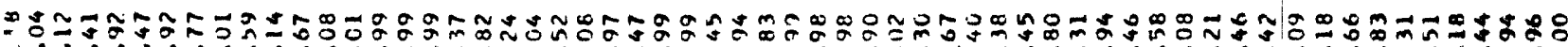

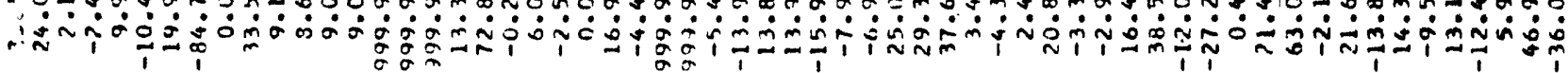

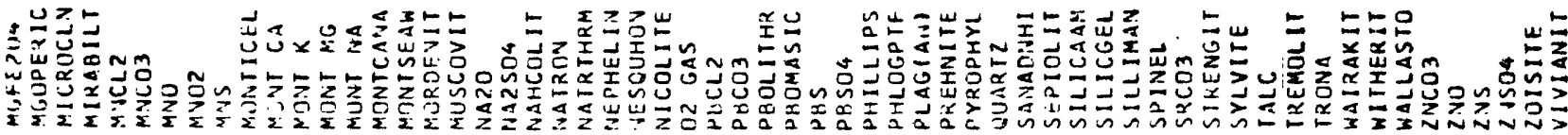

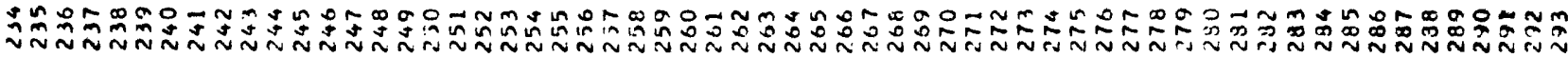




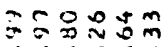

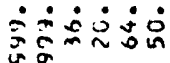

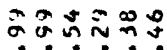

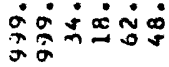

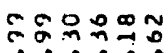

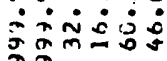

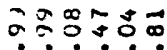

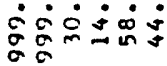

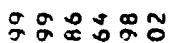

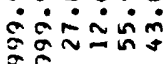

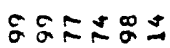

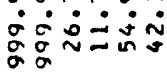

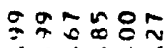

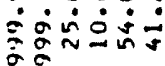

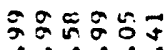

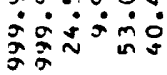

ลํำบำ

gू

Eg类品

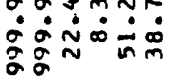

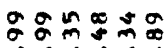

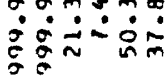

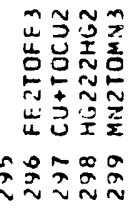




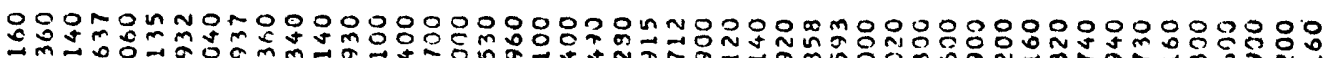

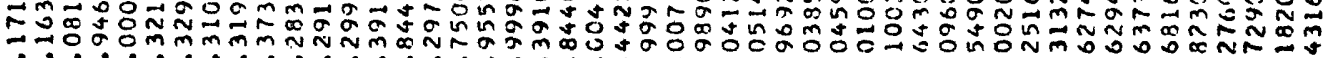

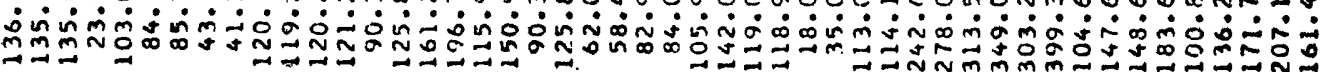

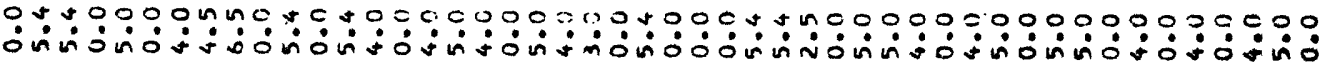

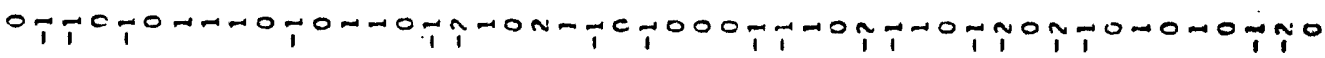

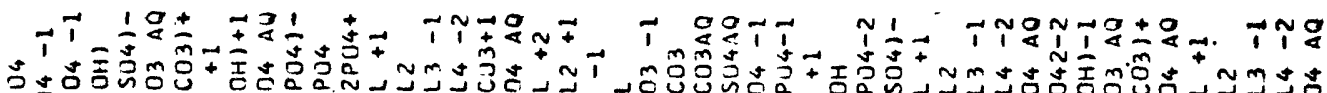

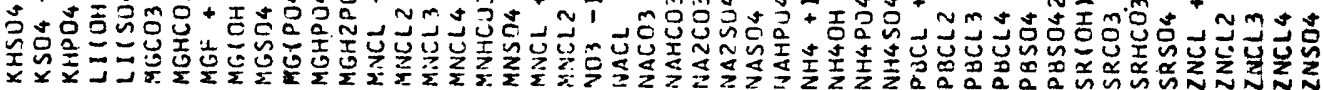

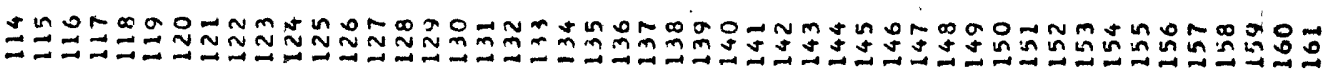

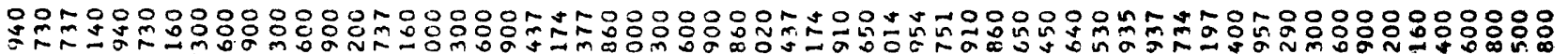

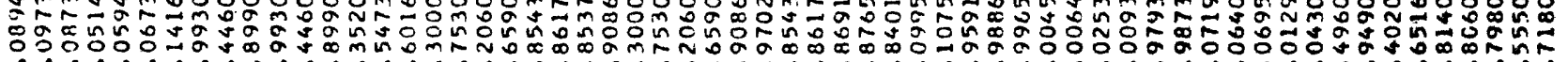

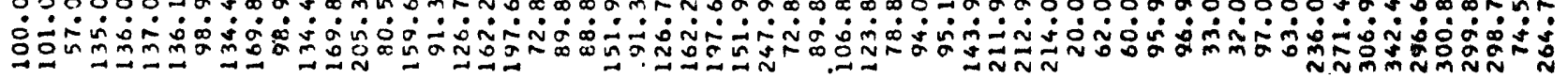

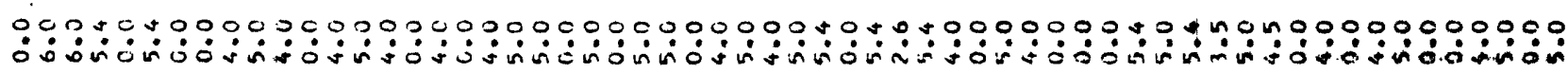

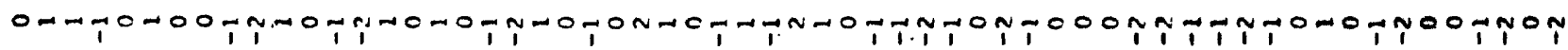

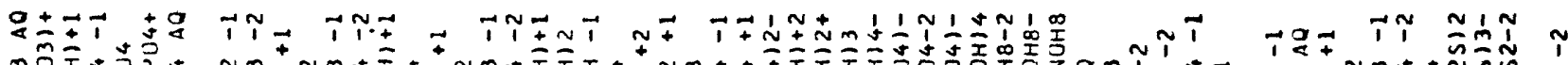

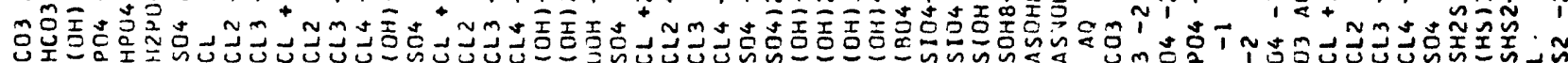

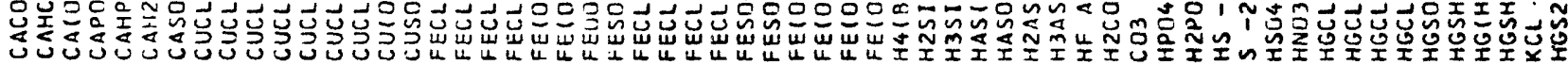

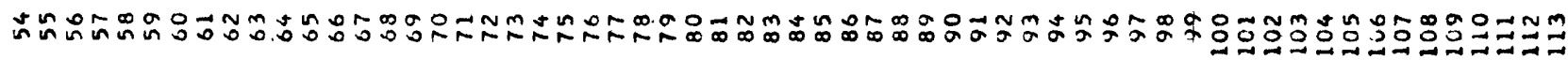

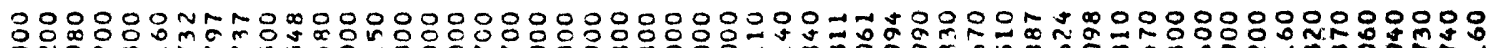

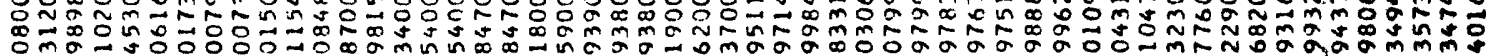

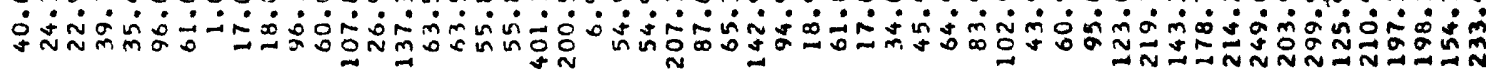

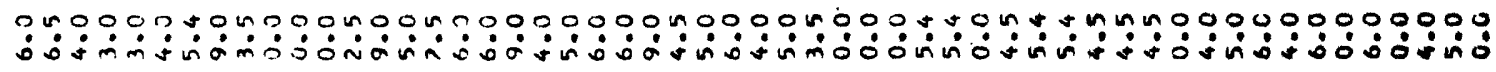

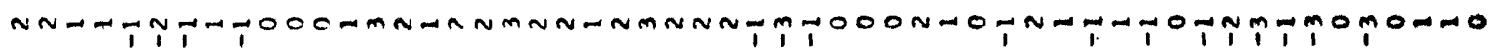

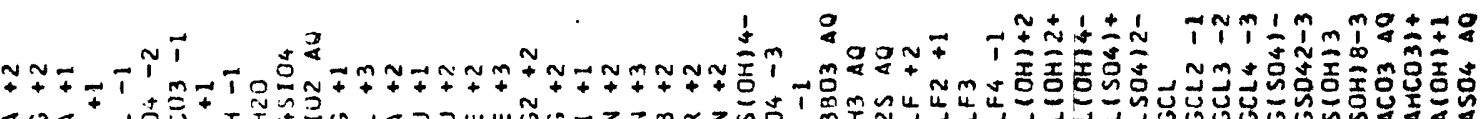

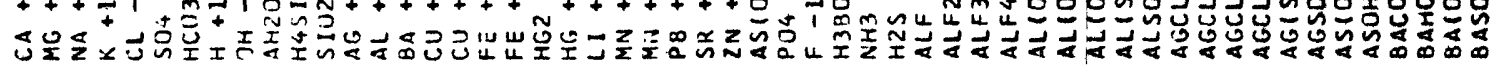

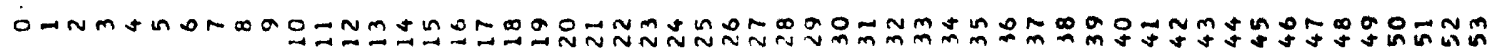



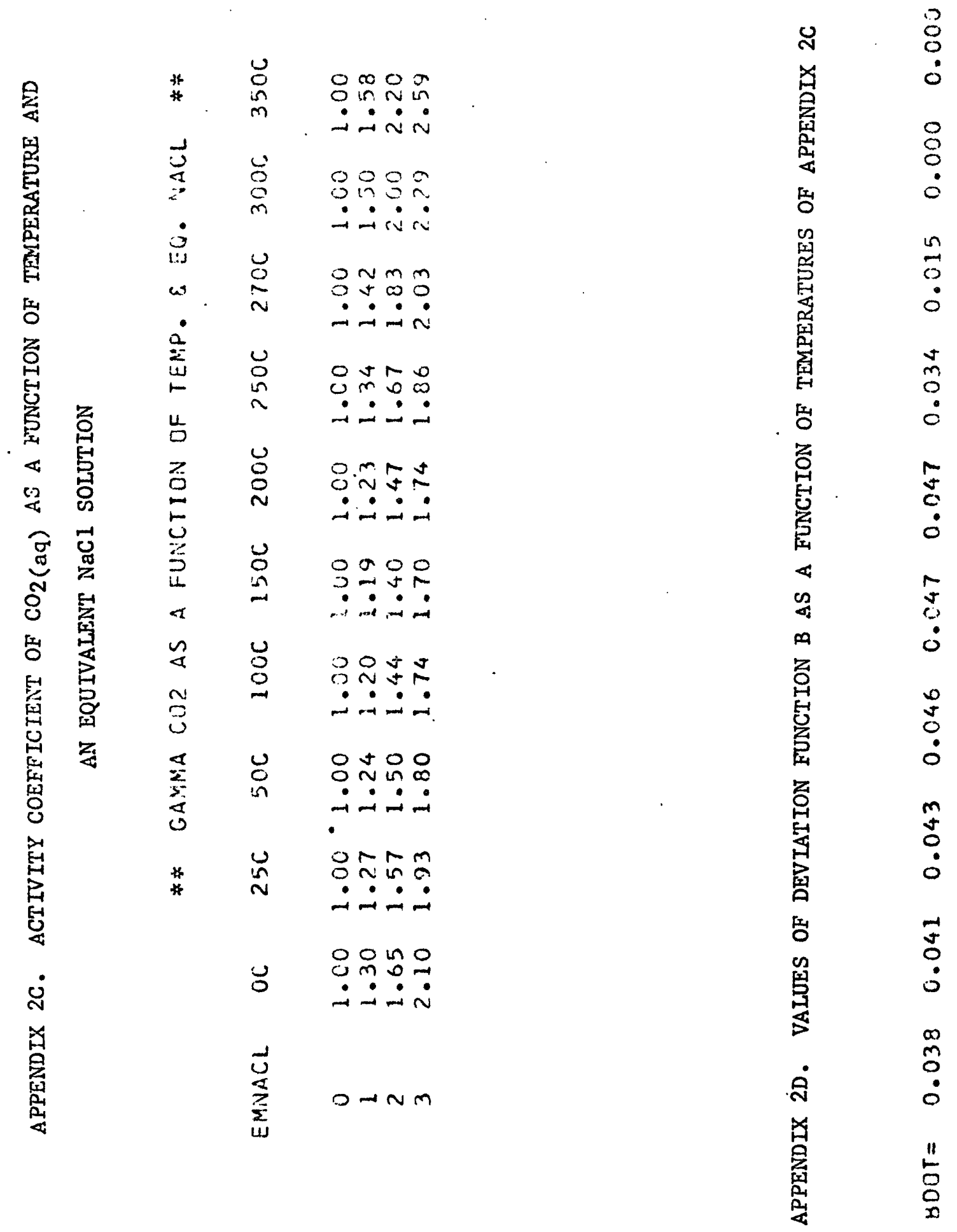


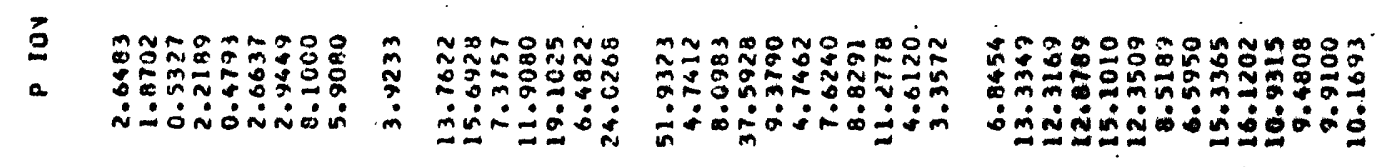

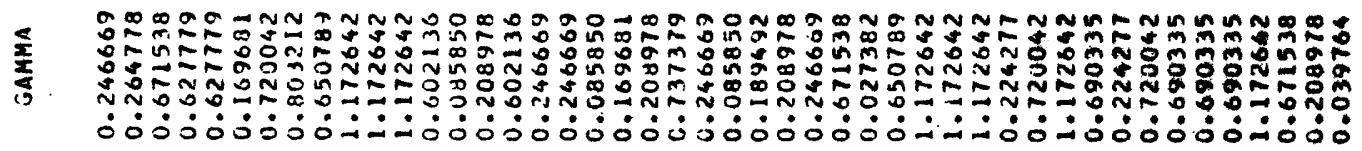

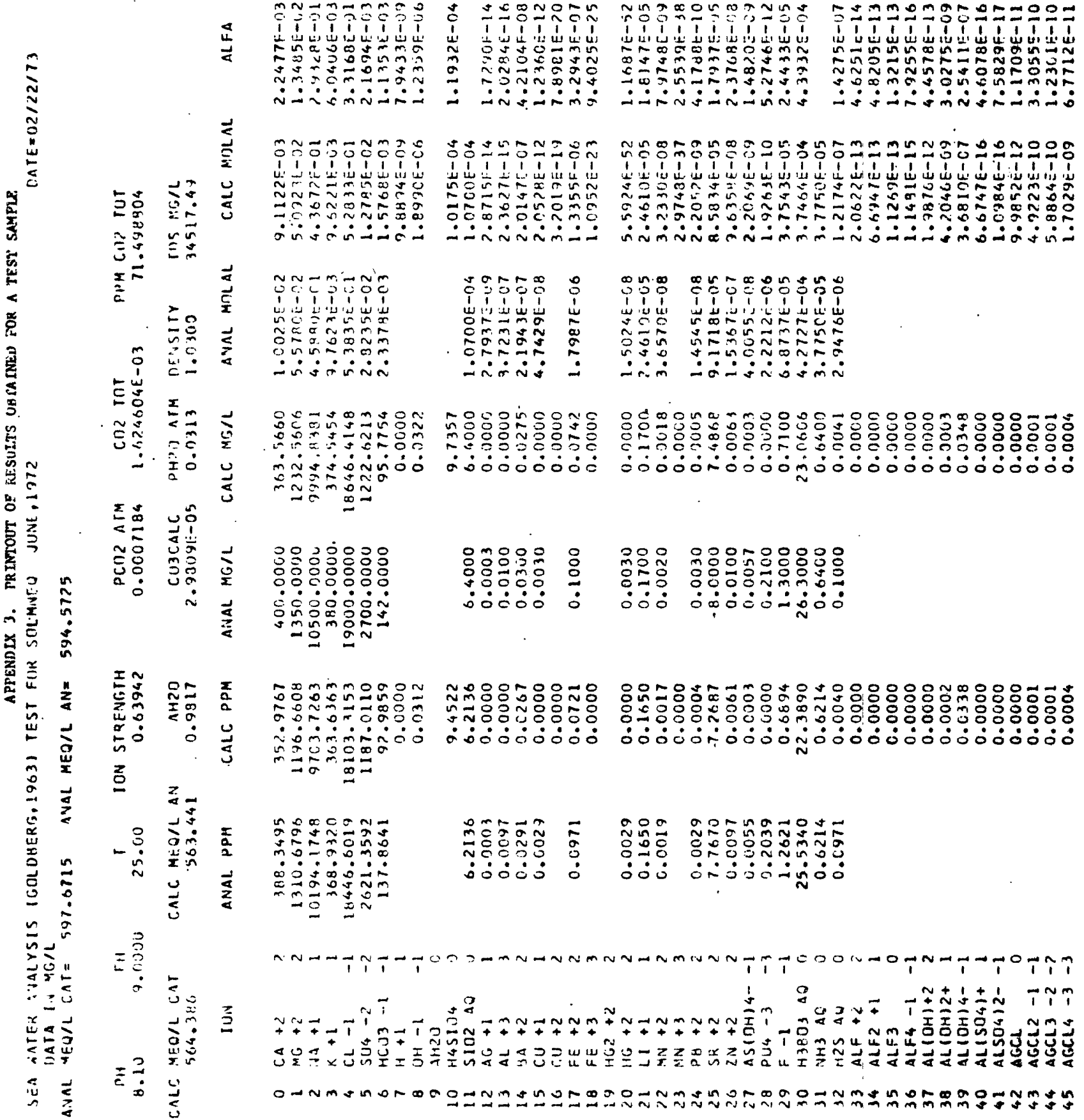




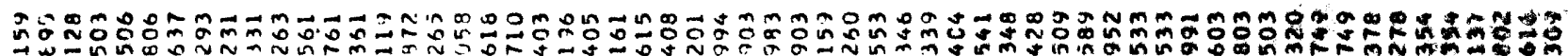

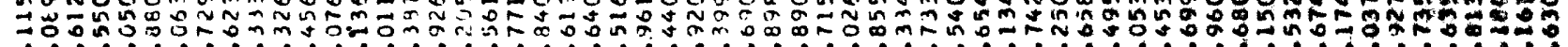

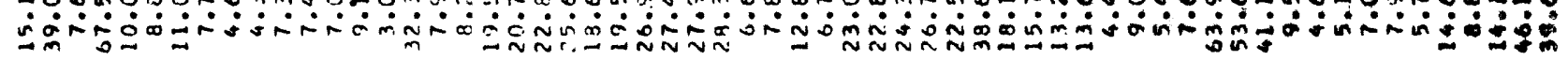

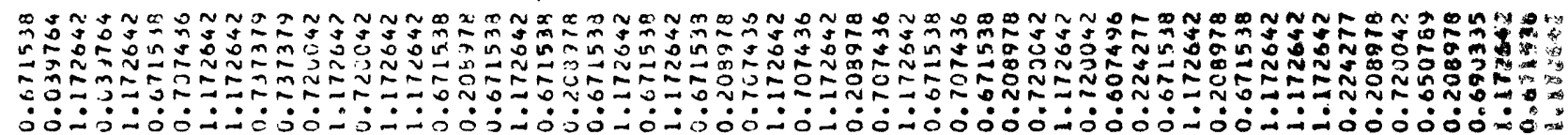

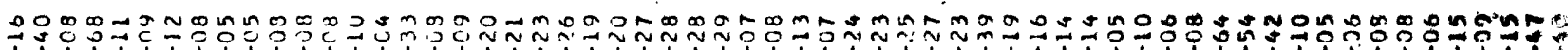

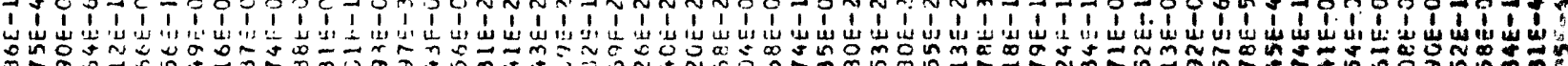

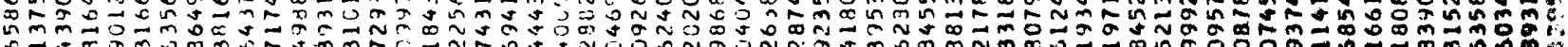

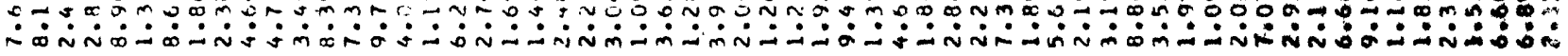

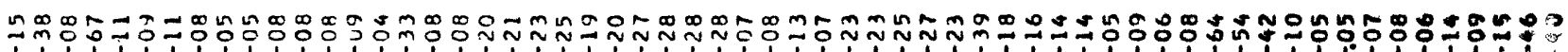

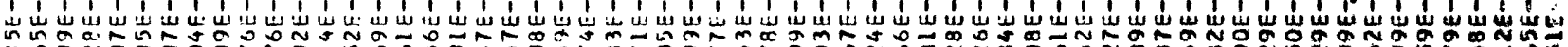
J

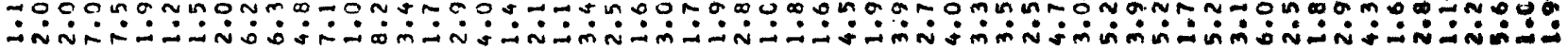

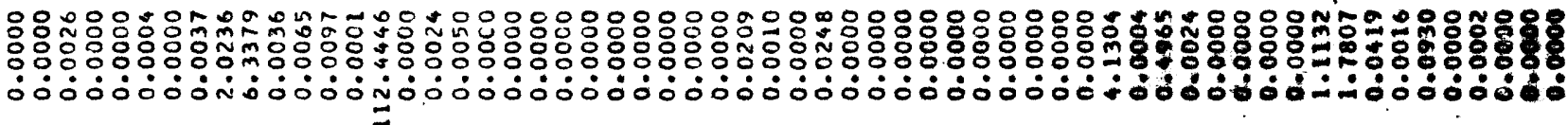

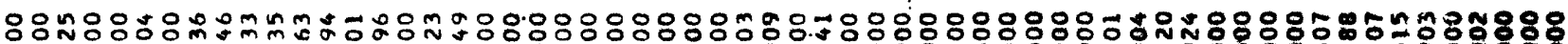

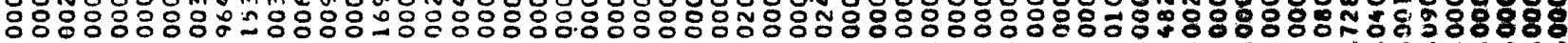

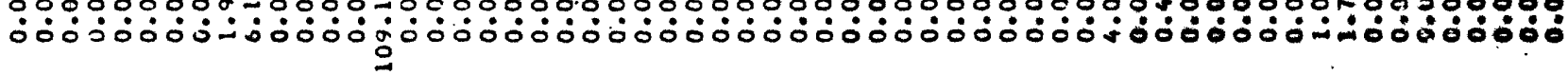

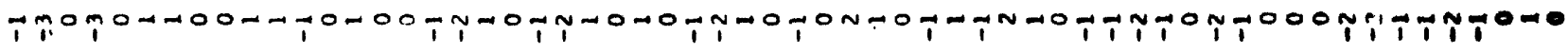

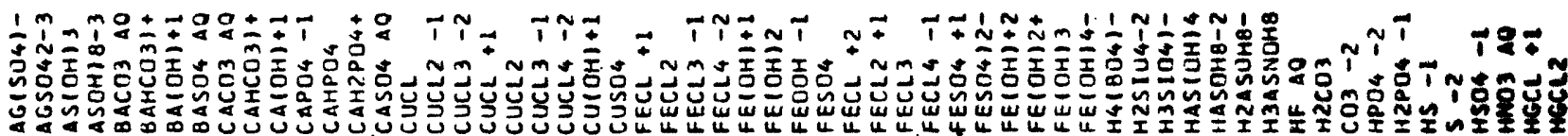

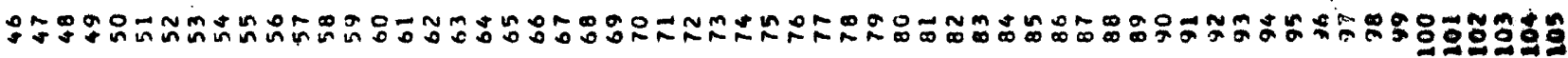

i $\quad+3$ 


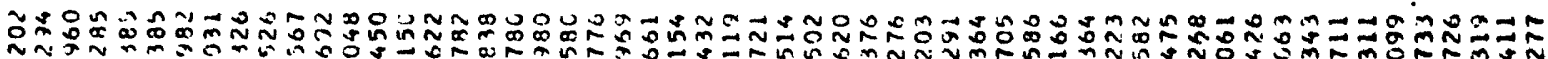

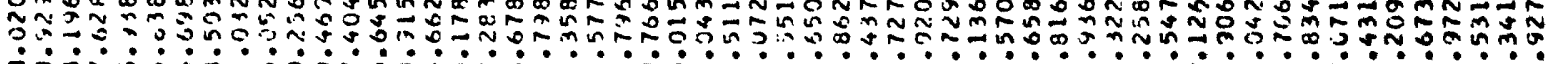

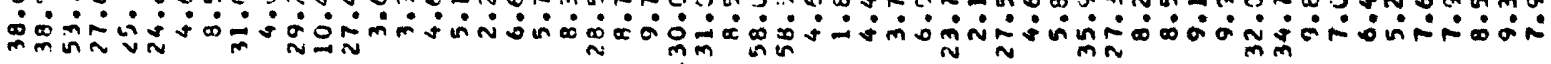

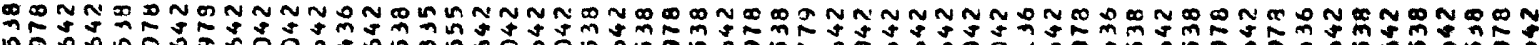

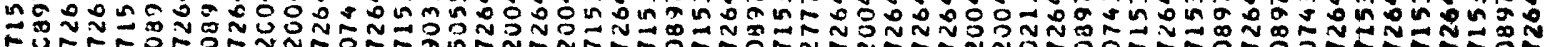
on

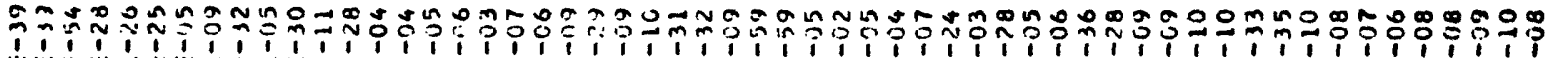

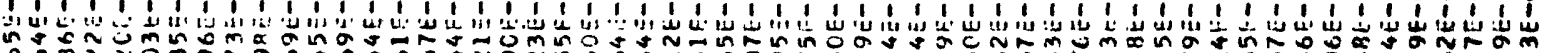

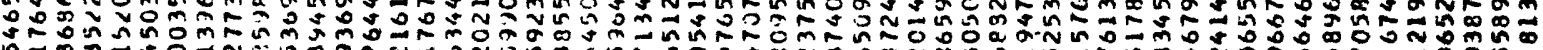

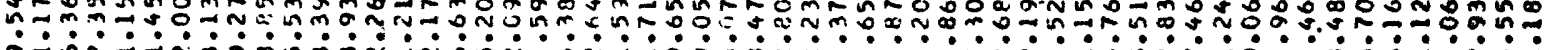

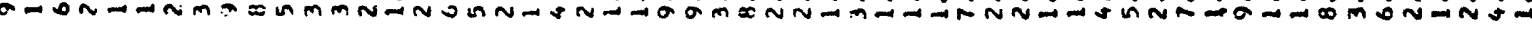

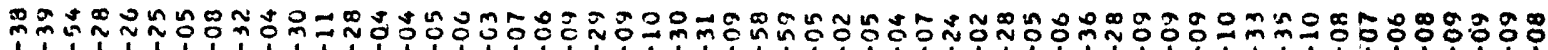

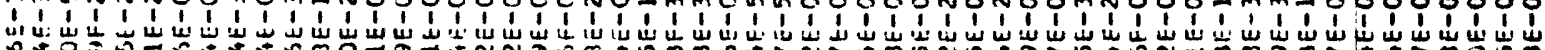

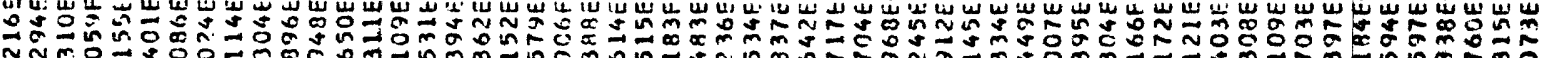

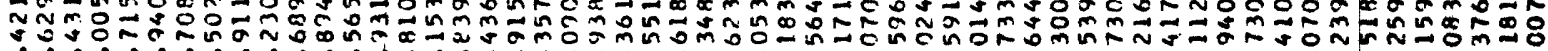

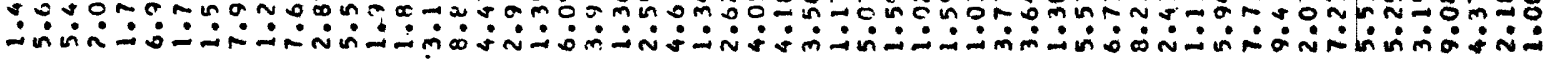

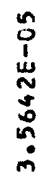

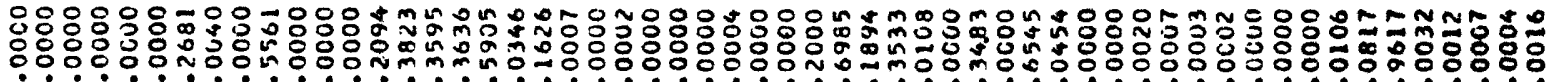

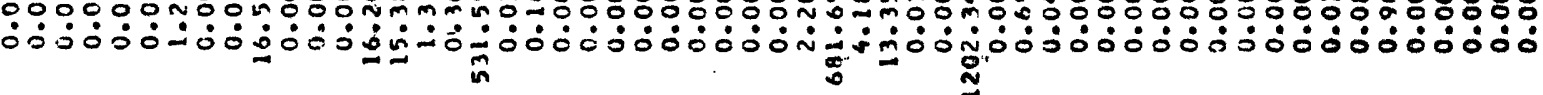<smiles>N#[W]</smiles>

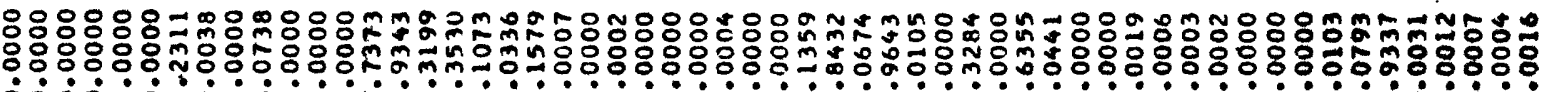

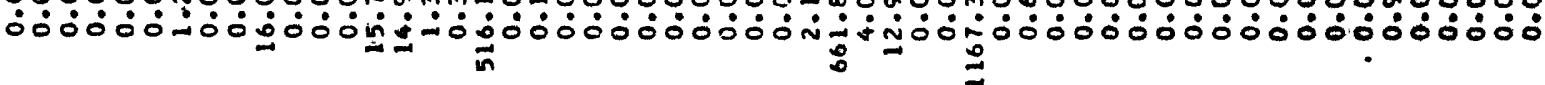

t4 Tิ

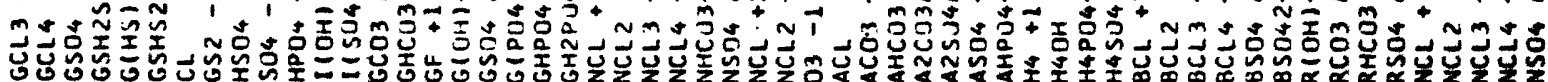

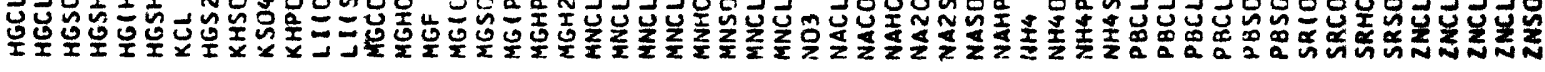

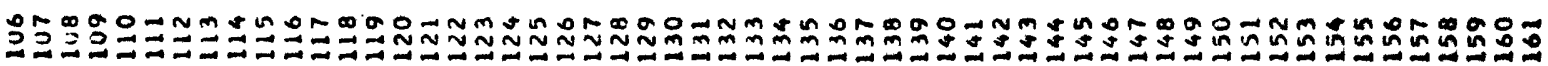




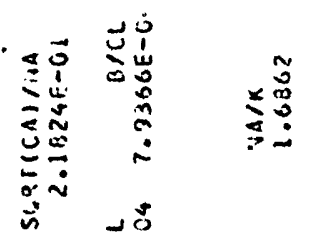

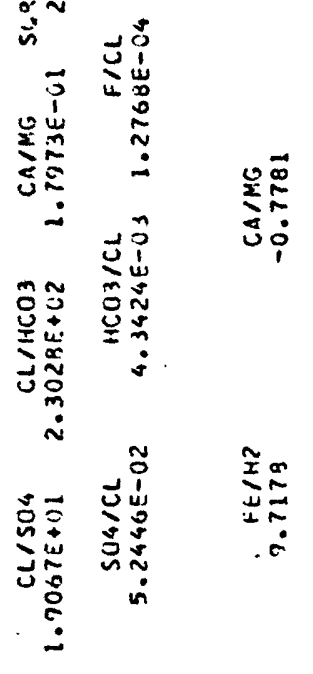

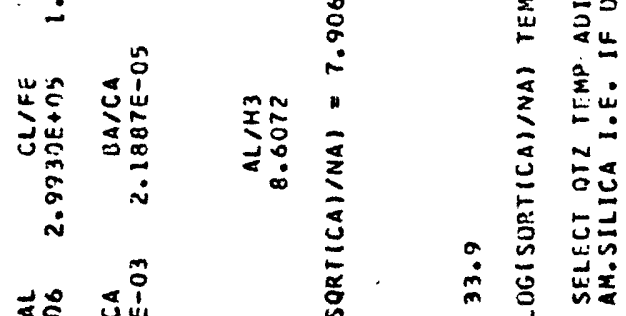

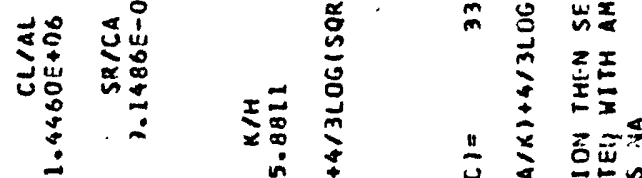

范

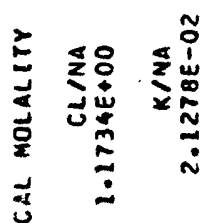

突㖞

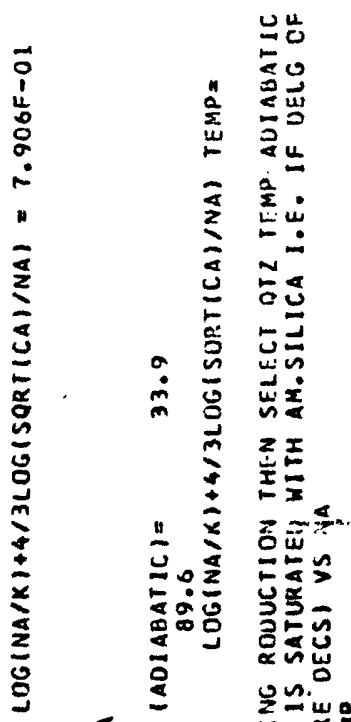

ธำ

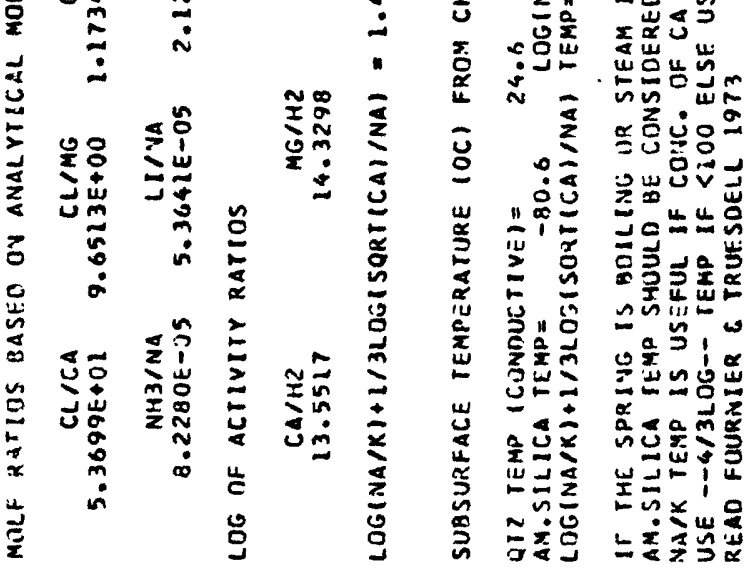


I

o
o

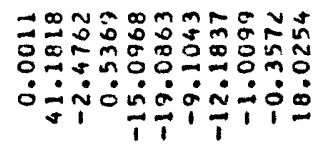

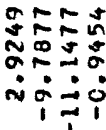

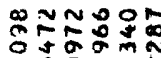

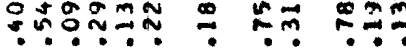

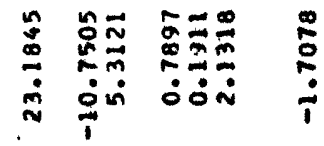

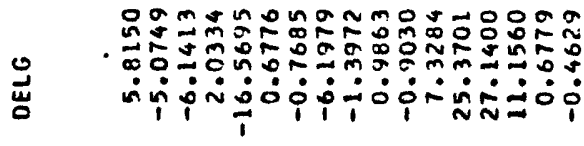

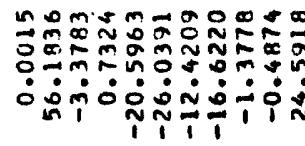

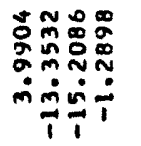

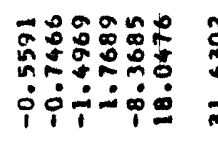

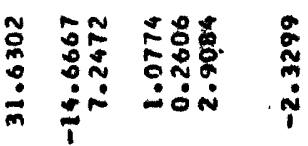

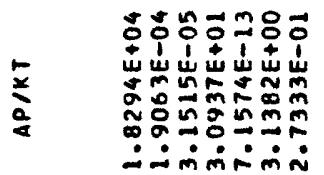

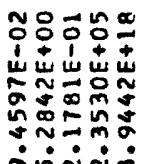

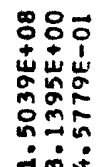

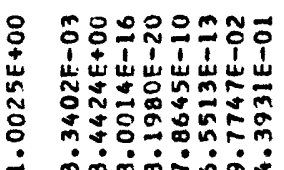

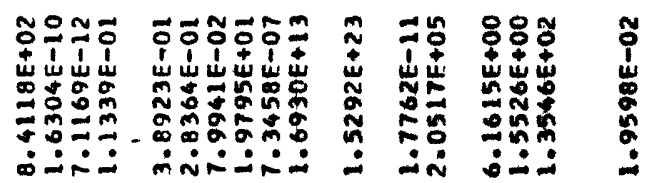

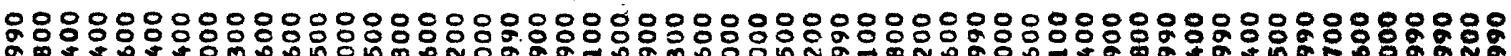

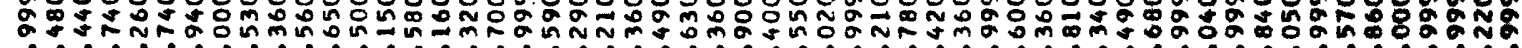

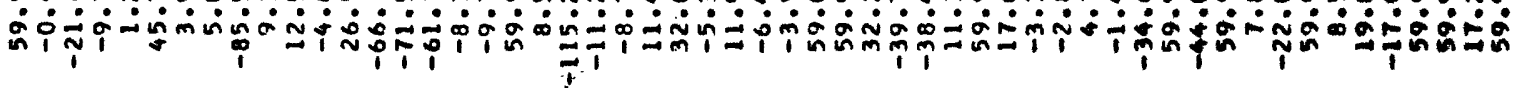

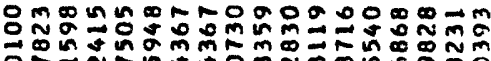

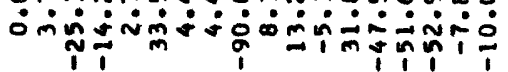

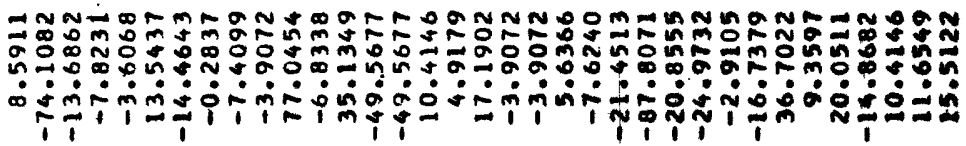

莗

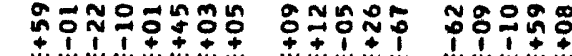

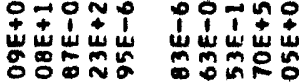

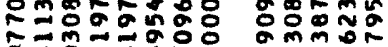

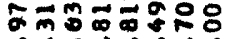

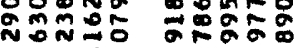

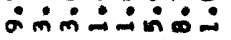

inininis

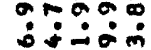

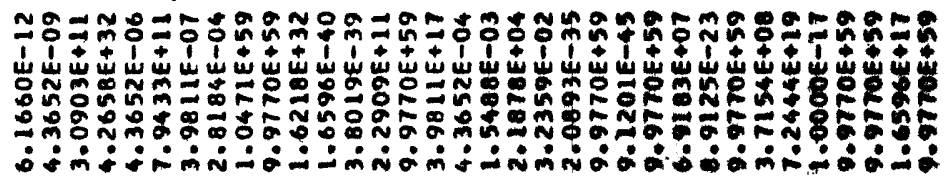

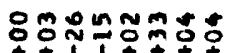

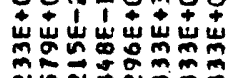

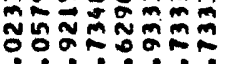

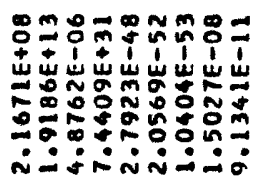

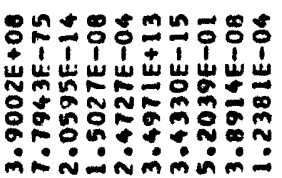
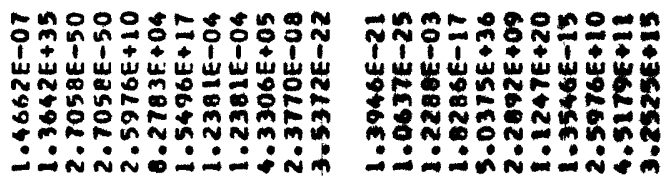

$\therefore \dot{0} \operatorname{inimin}$

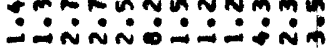

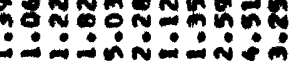

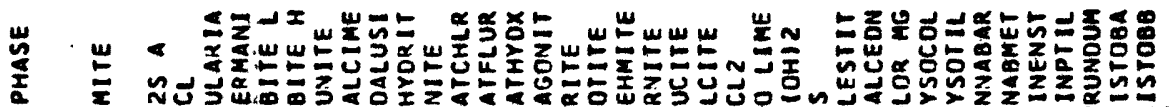

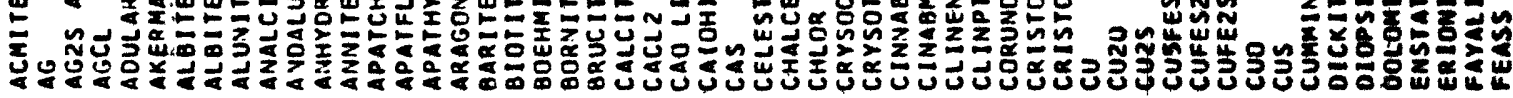

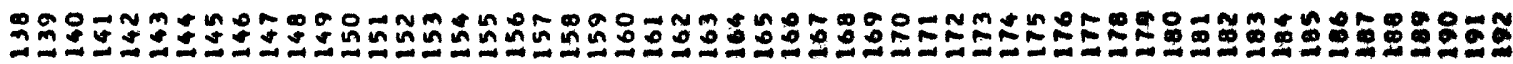



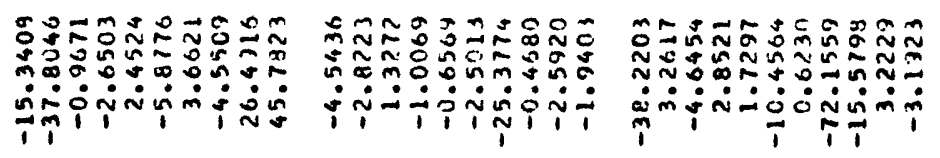

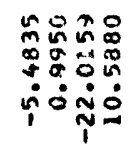

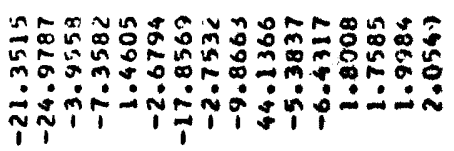

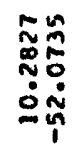

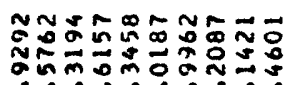
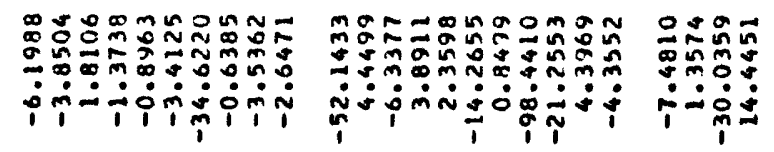

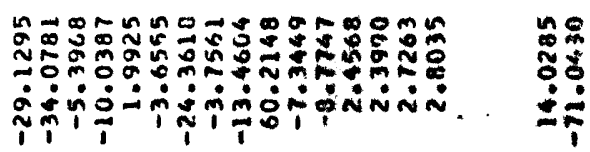

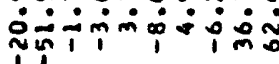

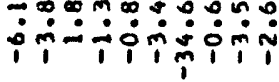

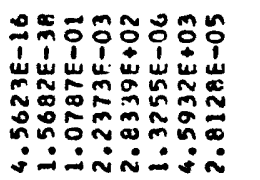

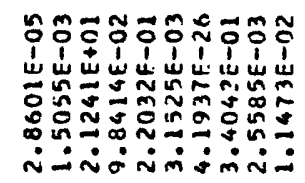

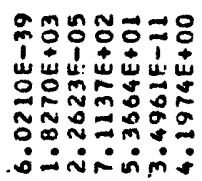

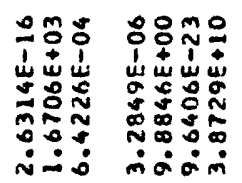

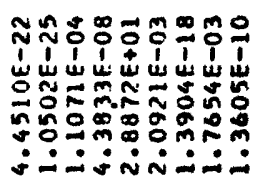

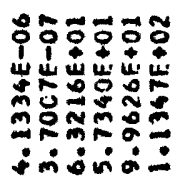

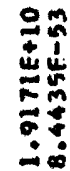

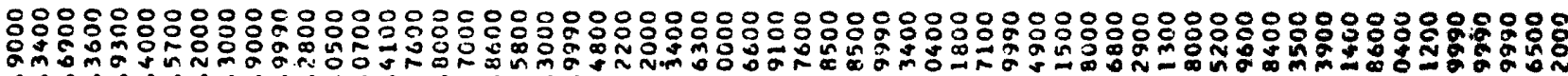

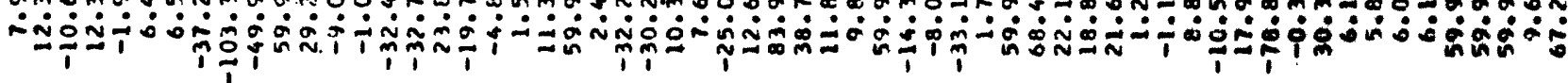

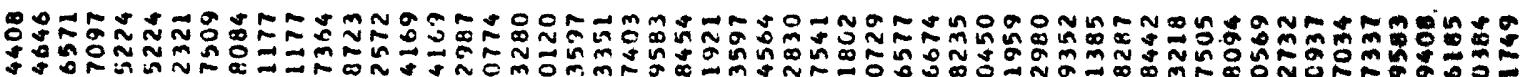

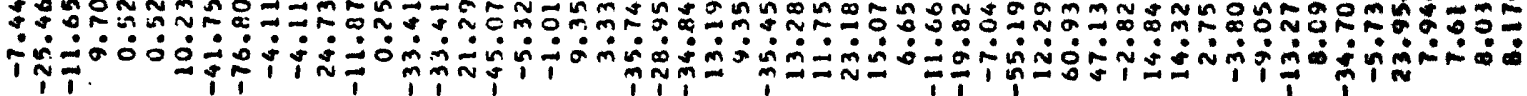

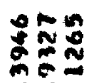
iी
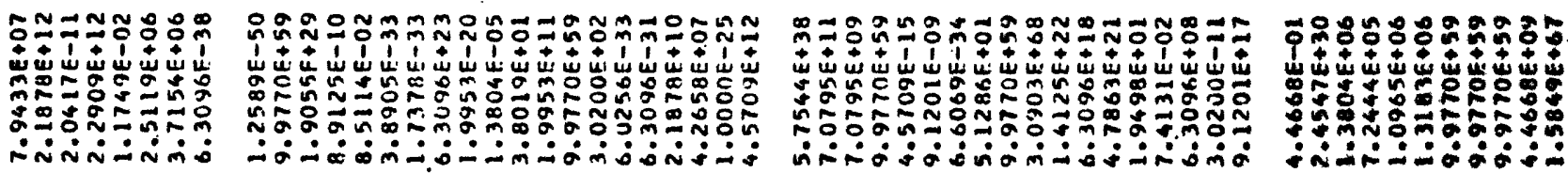

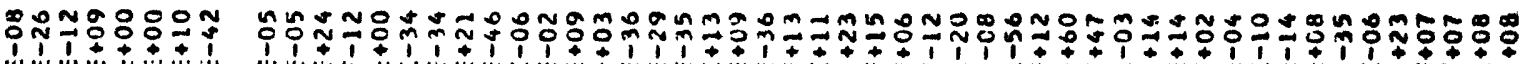

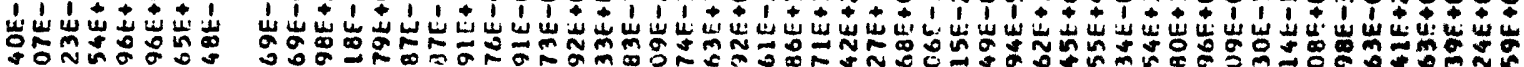

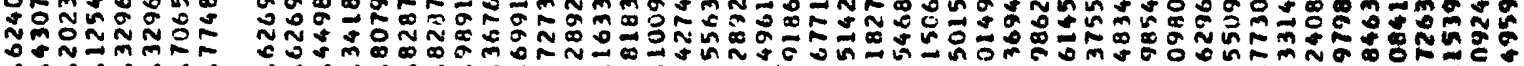

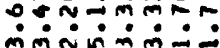

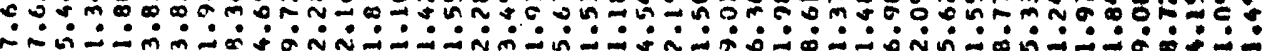

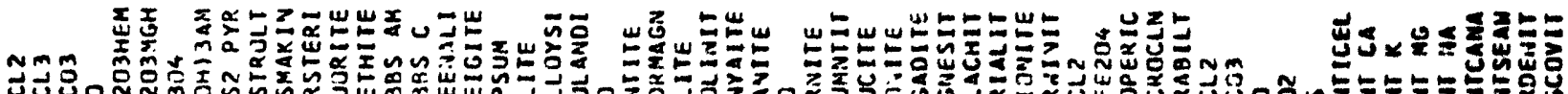

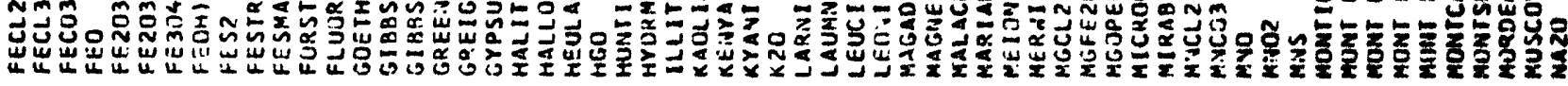

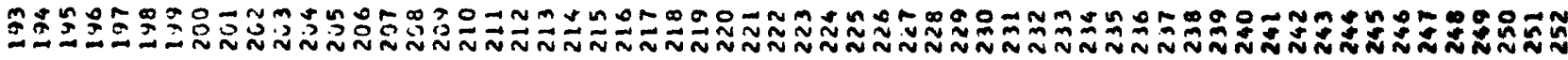

